\title{
Report on Qualitative Validation Experiments Using Lithium-Aluminum Layered Double-Hydroxides for the Reduction of Aluminum from the Waste Treatment Plant Feedstock
}

\author{
H. J. Huber \\ J. B. Duncan \\ G. A. Cooke \\ Washington River Protection Solutions LLC
}

Date Published

April 2010 


\section{Table of Contents}

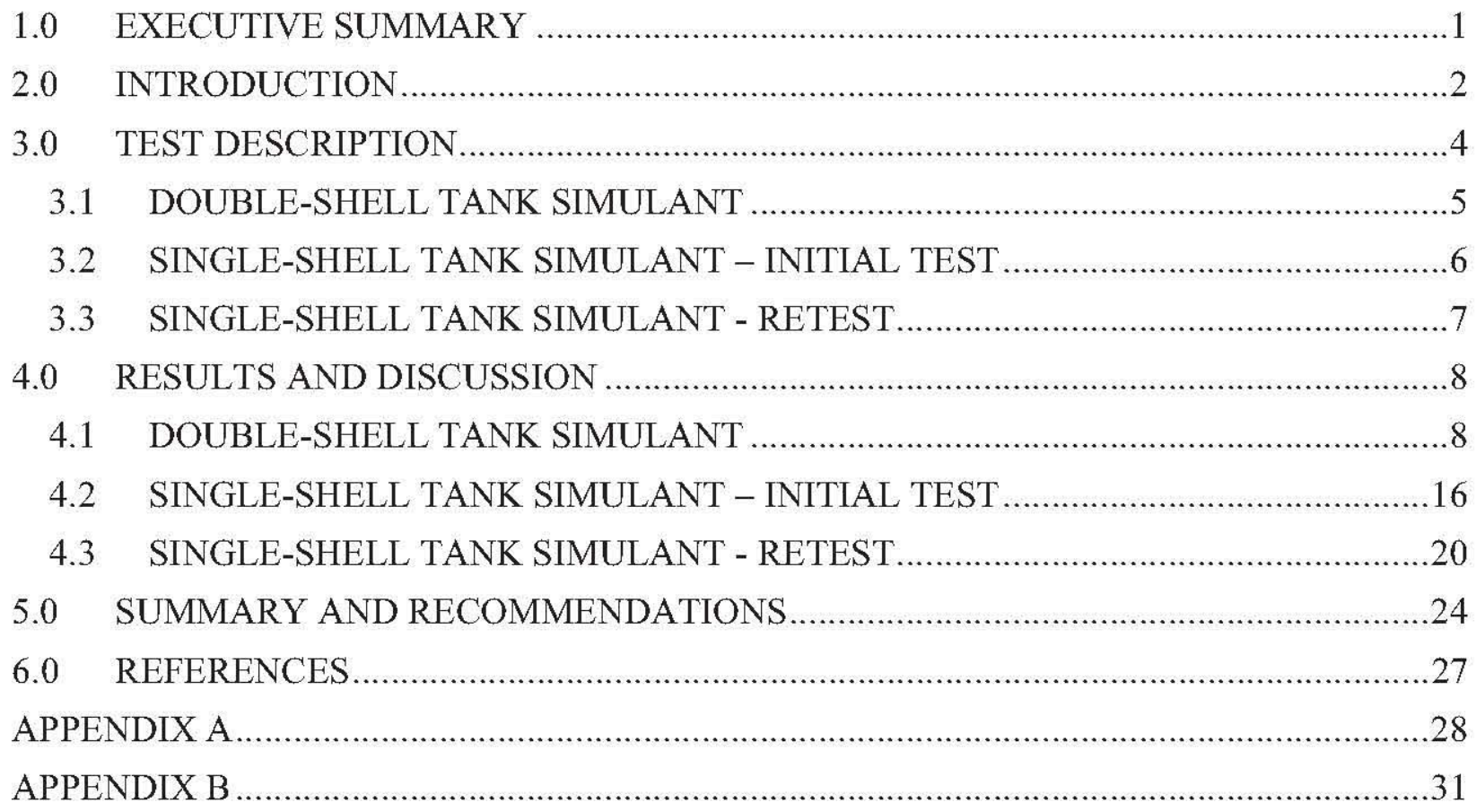

\section{List of Tables}

Table 1. Double-Shell Tank Simulant Chemical Makeup (1-L Batch) .................................5

Table 2. Single-Shell Tank Simulant Chemical Makeup (1-L Batch) ................................ 6

Table 3. Comparison of Amounts Used in Supernate Preparation and Amounts Analyzed After

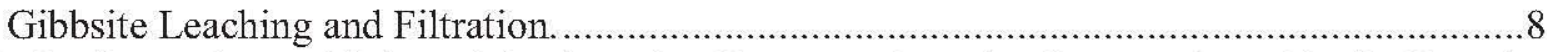

Table 4. Comparison of Selected Analytes in Filtrates and Wash Filtrates of Double-Shell Tank

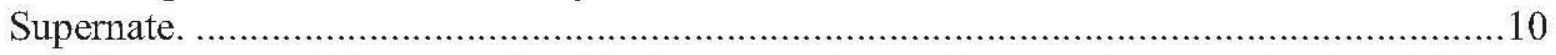

Table 5. Comparison of Amounts Used in Supernate Preparation and Amounts Analyzed After

Gibbsite Leaching and Filtration................................................................... 16

Table 6. Comparison of Selected Analytes in Filtrates and Wash Filtrates of Single-Shell Tank

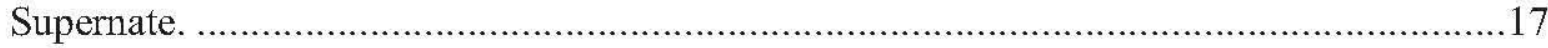

Table 7. Comparison of Yield and Turbidity with Lithium, Aluminum and Phosphorus

Concentrations for the Single-Shell Tank Simulant Retests...................................21

Table 8. Amounts of Assorted Analytes Retained in the Washed Filter Cakes. ......................224

Table 9. Solubility Products and Solubilities for Different Lithium Compounds....................25 


\section{List of Figures}

Figure 1. Lithium-Hydrotalcite Schematic........................................................................

Figure 2. Flow Chart for Preparation of Lithium Hydrotalcite. ......................................... 4

Figure 3. Double-Shell Tank Simulant Product after Four Hours of Ripening and Unwashed

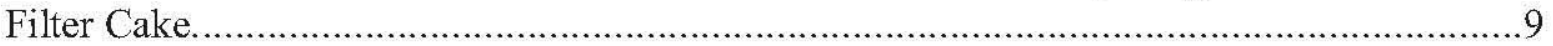

Figure 4. Final Water-Washed Filter Cake from Double-Shell Tank Simulant.......................9

Figure 5. Comparison of Aliquots of the Filtrate and Wash Filtrates from Double-Shell Tank Simulant Filter Cake.

Figure 6. Comparison of Mol\% of Selected Analytes in Filtrates from Double-Shell Tank

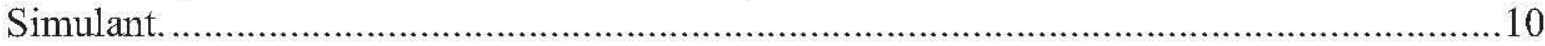

Figure 7. Comparison of Mol\% of Selected Analytes in Filtrates from Double-Shell Tank

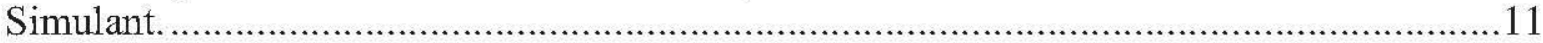

Figure 8. Polarized Light Microscopy Image of Double-Shell Tank Simulated Filter Cake.......12

Figure 9. Back Scattered Electron Image and Energy Dispersive Spectrometry Spectrum of

Double-Shell Tank Filter Cake Product. .................................................................13

Figure 10. Back Scattered Electron Image and Energy Dispersive Spectrometry Spectrum of

Double-Shell Tank Simulant Filter Cake. .........................................................................13

Figure 11. X-Ray Diffractogram of Double-Shell Tank Simulant Filter Cake.......................15

Figure 12. Thermal Gravimetric Analysis Spectrum of Double-Shell Tank Simulant Filter Cake.

Figure 13. Single-Shell Tank Simulant Product after Two Hours of Ripening and Washed Filter

Cake.

Figure 14. Comparison of Aliquots of the Filtrate and Wash Filtrates from Single-Shell Tank

Simulant Filter Cake.

Figure 15. Comparison of Mol\% of Selected Analytes in Filtrates from Single-Shell Tank

Supernate.

Figure 16. Comparison of Mol\% of Selected Analytes in Filtrates from Single-Shell Tank

Supernate.

Figure 17. Polarized Light Microscopy Image of the Single-Shell Tank Simulant Filter Cake. .19

Figure 18. Back Scattered Electron Image and Energy Dispersive Spectrometry Spectrum of the

Single-Shell Tank Simulant Filter Cake...................................................................19

Figure 19. X-Ray Diffractogram of the Single-Shell Tank Filter Cake Product.....................20

Figure 20. Single-Shell Tank Simulant Retest Product after Four Hours of Ripening..............20

Figure 21. Images of the Single-Shell Tank Simulant Retest Filter Cake for the Three Different

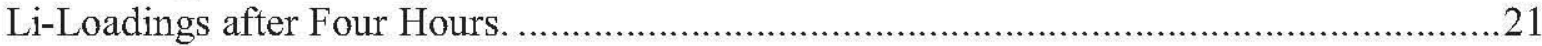

Figure 22. Back Scattered Electron Images and Energy Dispersive Spectrometry Spectra of

Single-Shell Tank Simulant Retest Filter Cake after 30 Minutes. .................................22

Figure 23. Back Scattered Electron Images and Energy Dispersive Spectrometry Spectra of

Single-Shell Tank Simulant Retest Filter Cake after Four Hours................................23

Figure 24. X-Ray Diffraction Spectrum of 0.4 M-Li Single-Shell Tank Simulant Retest Filter

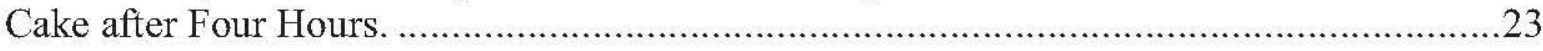




\title{
List of Terms
}

\author{
Abbreviations \\ ARF \\ ATL \\ BSE \\ D.I. \\ DST \\ EDS \\ IC \\ ICP-AES \\ ICP-MS \\ LiHT \\ PLM \\ SEM \\ SST \\ TIC/TOC \\ TGA \\ WTP \\ XRD \\ Aluminum Removal Facility \\ Advanced Technologies and Laboratories, Int1. \\ Back Scattered Electron \\ De-ionized \\ Double-Shell Tank \\ Energy Dispersive Spectrometry \\ Ion Chromatography \\ Inductively Coupled Plasma - Atomic Emission Spectroscopy \\ Inductively Coupled Plasma - Mass Spectroscopy \\ Lithium Hydrotalcite \\ Polarized Light Microscopy \\ Scanning Electron Microscopy \\ Single-Shell Tank \\ Total Inorganic Carbon/Total Organic Carbon \\ Thermal Gravimetric Analysis \\ Waste Treatment and Immobilization Plant \\ $\mathrm{X}$-ray Diffraction
}

\section{Units}

$\begin{array}{ll}\mathrm{g} & \text { Gram } \\ \mathrm{M} & \text { Molar } \\ \mu \mathrm{g} & \text { Microgram } \\ \mathrm{L} & \text { Liter } \\ \mathrm{mL} & \text { Milliliter } \\ \text { NTU } & \text { Nephelometric Turbidity Unit }\end{array}$

Nephelometric Turbidity Unit 


\subsection{EXECUTIVE SUMMARY}

- A process for removing aluminum from tank waste simulants by adding lithium and precipitating $\mathrm{Li}$-Al-dihydroxide (Lithiumhydrotalcite, $\left[\mathrm{LiAl}_{2}(\mathrm{OH})_{6}\right]^{+} \mathrm{X}^{-}$) has been verified. The tests involved a double-shell tank (DST) simulant and a single-shell tank (SST) simulant. In the case of the DST simulant, the product was the anticipated Li-hydrotalcite. For the SST simulant, the product formed was primarily $\mathrm{Li}$-phosphate. However, adding excess $\mathrm{Li}$ to the solution did result in the formation of traces of Li-hydrotalcite.

- The Li-hydrotalcite from the DST supernate was an easily filterable solid. After four water washes the filter cake was a fluffy white material made of $<100 \mu \mathrm{m}$ particles made of smaller spheres. These spheres are agglomerates of $\sim 5 \mu \mathrm{m}$ diameter platelets with $<1 \mu \mathrm{m}$ thickness. Chemical and mineralogical analyses of the filtrate, filter cake, and wash waters indicate a removal of $90+w t \%$ of the dissolved $\mathrm{Al}$ for the DST simulant.

- For the SST simulant, the main competing reaction to the formation of lithium hydrotalcite appears to be the formation of lithium phosphate. In case of the DST simulant, phosphorus co-precipitated with the hydrotalcite. This would imply the added benefit of the removal of phosphorus along with aluminum in the pre-treatment part of the waste treatment and immobilization plant (WTP).

- For this endeavor to be successful, a serious effort toward process parameter optimization is necessary. Among the major issues to be addressed are the dependency of the reaction yield on the solution chemistry, as well as residence times, temperatures, and an understanding of particle growth. 


\subsection{INTRODUCTION}

The reduction of aluminum would benefit the operations of the WTP by both a substantial reduction in the volume of glass produced and a reduction in the duration of operations. The recently published River Protection Project System Plan Rev. 4 (ORP-11242) includes a proposal for an aluminum removal facility (ARF). The ARF would reduce the amount of aluminum in the feed to the WTP by 5,900 $\mathrm{MT}^{1}$ via the formation of insoluble LithiumHydrotalcite $\left(\mathrm{LiHT}^{2}\right)$ and has the potential to recycle sodium hydroxide to the sludge leaching process.

As indicated in the general reaction in Equation 2-1, lithium combines with the aluminate ion to form the Li-Al-dihydroxide complex with intercalated anions and water molecules. The excess sodium hydroxide generated by the reaction could be recycled for caustic leaching of aluminumbearing solids from tank farm sludges to increase the amount of sodium aluminate $\left[\mathrm{NaAl}(\mathrm{OH})_{4}\right]$ in the supernate.

$$
2 \mathrm{NaAl}(\mathrm{OH})_{4}+\mathrm{LiOH}+\mathrm{NaX}^{-}+\mathrm{nH}_{2} \mathrm{O} \rightarrow\left[\mathrm{LiAl}_{2}(\mathrm{OH})_{6}\right] \mathrm{X}^{-} \cdot \mathrm{nH}_{2} \mathrm{O}+3 \mathrm{NaOH}
$$

The schematic drawing in Figure 1 addresses the structure with examples of $\mathrm{CO}_{3}, \mathrm{NO}_{3}$, and $\mathrm{OH}$ ions dispersed. Of these anions, carbonate is the most likely to be intercalated $\left(\left[\mathrm{LiAl}_{2}(\mathrm{OH})_{6}\right]_{2} \mathrm{CO}_{3}\right)$.

Figure 1. Lithium-Hydrotalcite Schematic.

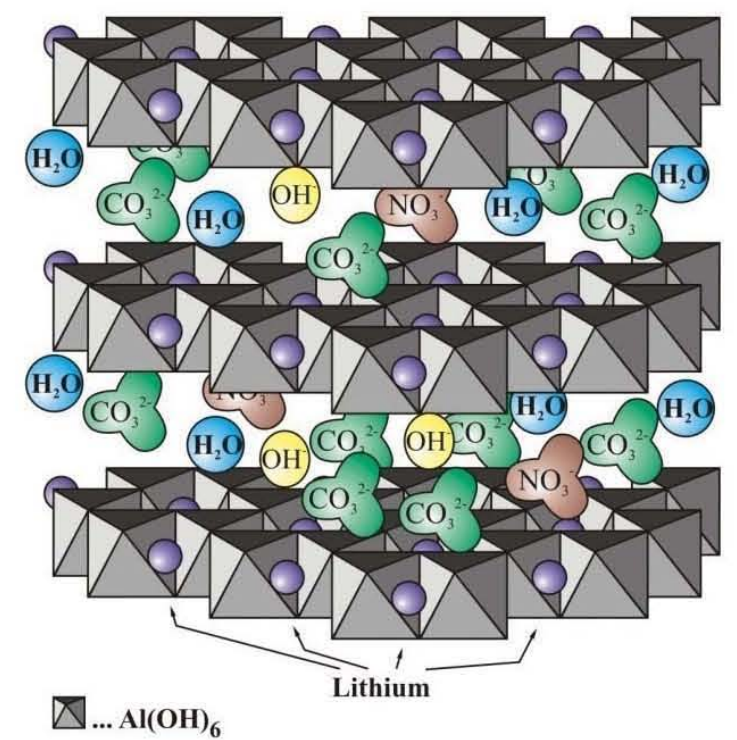

\footnotetext{
${ }^{1}$ Based on Figure 5-1 in the System Plan R4 this amount can be calculated: $\{23,900 \mathrm{MT}$ Li-hydrotalcite $/ 440 \mathrm{~g} / \mathrm{mol}$ (mol. wt. Li-hydrotalcite) $\}$ x 4 (Al per Li-hydrotalcite) x $27 \mathrm{~g} / \mathrm{mol}$ (mol. wt. Al) =5,866 MT Al.

${ }^{2}$ The mineralogically appropriate term would be Lithium-Aluminum Layered Double-Hydroxide Hydrate. Hydrotalcite is defined as the substance Mg-Al-Double-Hydroxide. However, the term Li-hydrotalcite was coined. in the literature over the last 50 years and will be used henceforth in this report.
} 
The 222-S Laboratory at US Department of Energy Hanford Site was tasked to verify the precipitation of aluminum using lithium hydroxide as proposed by AREVA Corporation ${ }^{3}$. AREVA has applied for an international patent ${ }^{4}$ on the application of this process to remove aluminum from aqueous solutions. The basic reaction of precipitating $\mathrm{Li}$-Al-dihydroxide from a caustic Li-Al-bearing solution can be traced back to a publication entitled "The Action of Caustic Hydroxides on Aluminum" (Allen and Rodgers 1900). Recent industrial applications of this process were aimed toward producing nano-scale surface layers or to use hydrotalcites as drug delivery systems; therefore, although the chemistry of lithium hydrotalcite is well studied, reaction conditions in the literature are not directly adaptable to the removal of aluminum from tank waste.

To challenge the process, two Hanford tank simulants were used: one simulant representing DST chemistry and one representing SST chemistry. The tests were primarily designed to qualitatively verify the process' potential for the Hanford WTP, and to identify the areas of improvement.

A prior draft version of this report (LA-RPT-09-00003) and a presentation at the Office of River Protection educational forum contained preliminary chemical data. Any results and conclusions are superseded by this report presenting the Quality Control-verified chemical analyses. Appendix A contains the sample breakdown diagrams including the sample numbers. Appendix $\mathrm{B}$ is a compilation of the chemical data provided by the analytical laboratory.

\footnotetext{
${ }^{3}$ AREVA is a registered trademark of the Societe des Participations du Commissariat a l'Energie Atomique CORPORATION FRANCE, Paris, France.

${ }^{4}$ International Application No. PCT/US2008/076589 (A Process for Removal of Aluminum Oxides from Aqueous Media).
} 


\subsection{TEST DESCRIPTION}

The tests were performed as described in the associated test plan LAB-PLAN-09-00003, Validation of Initial Laboratory Experiments Using Lithium-Aluminum Layered DoubleHydroxides for the Reduction of Alumina from the Waste Treatment Plant Feedstock. All data and observations during the experiments were recorded in the controlled laboratory notebook HNF-N-586-2.

The general flow chart of the process is shown in Figure 2. It contains all steps including gibbsite leaching, crystal ripening at $90{ }^{\circ} \mathrm{C}$ (for 4 hours), filtration, and final wash steps. This procedure was applied to all test runs with slight modifications described in the individual chapters.

Figure 2. Flow Chart for Preparation of Lithium Hydrotalcite.

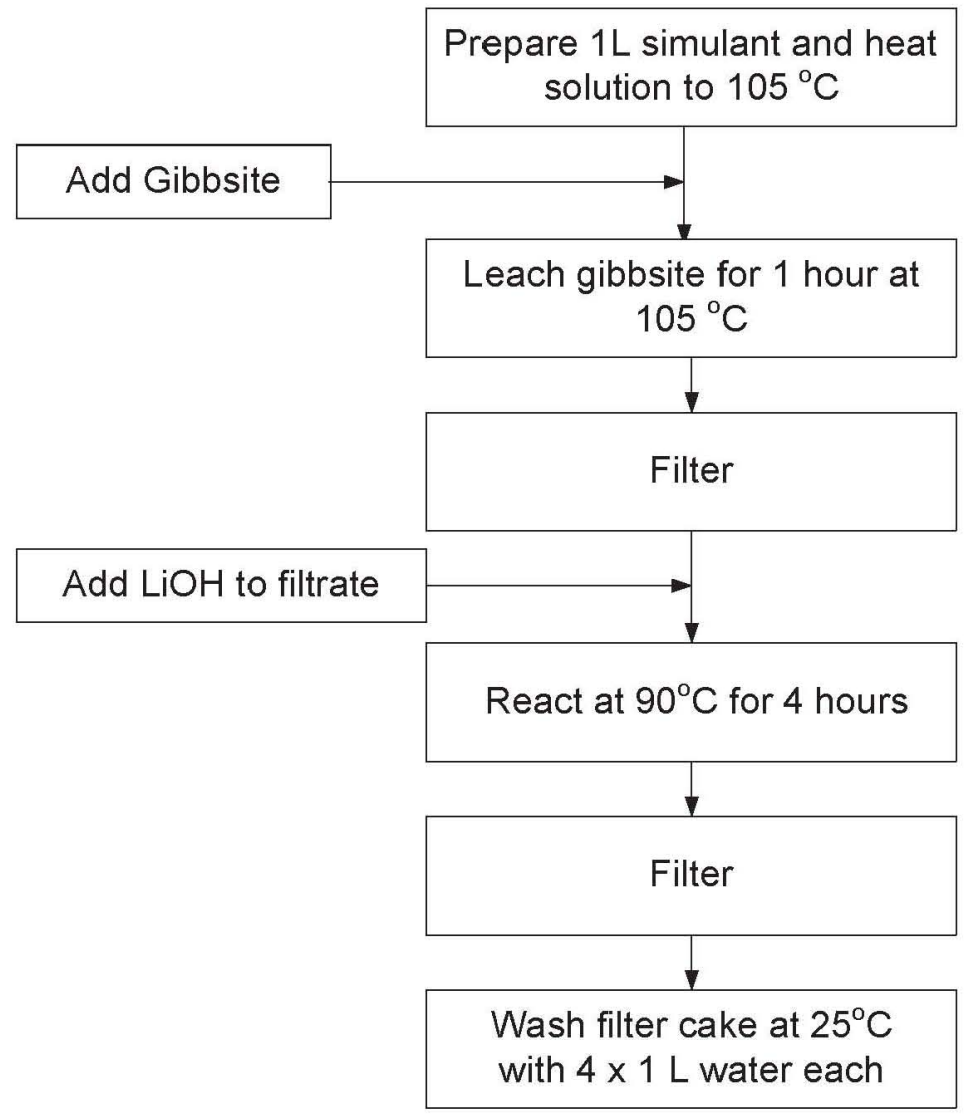

The SST and DST simulants were prepared according to the recipes in the test plan, with slight modifications. The original compositions were based on the descriptions of the SST early feed simulant and the DST simulant in CH2M-0403873, Preparation of Simulated Waste Samples for EM-21 Project. The DST simulant was prepared as a 5-M sodium version. The intent of the SST approach was to identify the boundaries of the process in terms of ionic strength and saturation of some anions. Therefore, the SST simulant was prepared with the original sodium molarity $(8.5 \mathrm{M})$. 
For each test, a glass beaker on a hot plate with a stir bar and thermocouple temperature controller was used. The glass reactor originally planned for these tests was not deliverable on short notice. Since the primary objective of these test runs was to qualitatively confirm the process, the approach using glass beakers was sufficient.

Samples for chemical analyses were taken from the wash water of each of the four washing steps, as well as from an aliquot of the filter cake. All samples were submitted to Advanced Technologies and Laboratories, Intl. (ATL) for analyses on $\mathrm{Li}, \mathrm{Al}, \mathrm{Cs}, \mathrm{P}, \mathrm{S}$, anions, total inorganic carbon/total organic carbon (TIC/TOC), free hydroxide, and percent water (using, e.g., inductively coupled plasma-atomic emission spectroscopy (ICP-AES), inductively coupled plasma-mass spectroscopy (ICP-MS), Ion Chromatography (IC), and thermal gravimetric analysis (TGA)). From the remaining filter cake, samples were taken for physical characterization using polarized light microscopy (PLM), scanning electron microscopy (SEM), and X-ray diffraction (XRD).

\subsection{DOUBLE-SHELL TANK SIMULANT}

The 1-L DST simulant was prepared at $60{ }^{\circ} \mathrm{C}$ in a 2-L glass beaker. Table 1 shows the composition of the simulant.

Table 1. Double-Shell Tank Simulant Chemical Makeup (1-L Batch).

\begin{tabular}{|l|c|c|c|}
\hline \multicolumn{1}{|c|}{ Reagent } & MW & Weight [g] & Amount [mol] \\
\hline $\mathrm{NaOH}$ & 40.0 & 103.63 & 2.59 \\
\hline $\mathrm{Na}_{2} \mathrm{CO}_{3}$ & 106.0 & 6.81 & 0.06 \\
\hline $\mathrm{Na}_{2} \mathrm{C}_{2} \mathrm{O}_{4}$ & 134.0 & 0.039 & 0.0003 \\
\hline $\mathrm{KNO}_{3}$ & 101.0 & 19.64 & 0.19 \\
\hline $\mathrm{NaNO}_{3}$ & 85.0 & 77.74 & 0.91 \\
\hline $\mathrm{NaNO}_{2}$ & 69.0 & 79.51 & 1.15 \\
\hline $\mathrm{Na}_{2} \mathrm{SO}_{4}$ & 142.0 & 1.02 & 0.007 \\
\hline $\mathrm{Na}_{3} \mathrm{PO}_{4} \cdot 12 \mathrm{H}_{2} \mathrm{O} \cdot 0.25 \mathrm{NaOH}$ & 390.1 & 2.81 & 0.007 \\
\hline $\mathrm{NaCl}^{\mathrm{NaF}}$ & 58.4 & 6.73 & 0.12 \\
\hline $\mathrm{Na}_{2} \mathrm{Cr}_{2} \mathrm{O}_{7} \cdot 2 \mathrm{H}_{2} \mathrm{O}$ & 42.0 & 0.45 & 0.01 \\
\hline $\mathrm{NaC}_{2} \mathrm{H}_{3} \mathrm{O}_{2} \cdot 3 \mathrm{H}_{2} \mathrm{O}$ & 298.0 & 0.43 & 0.001 \\
\hline $\mathrm{CsNO}_{3}{ }^{\mathrm{a}}$ & 136.1 & 5.44 & 0.04 \\
\hline $\mathrm{Al}(\mathrm{OH})_{3}{ }^{6}$ & 211 & 0.101 & 0.0005 \\
\hline
\end{tabular}

${ }^{a}$ Cs-nitrate was added as an aqueous solution of $210 \mathrm{mg}$ Cs-nitrate salt in $250 \mathrm{~mL}$ water.

${ }^{\mathrm{b}}$ Gibbsite was heat leached into the solution at $105^{\circ} \mathrm{C}$ for 1 hour.

The 1-L simulant was heated to $105^{\circ} \mathrm{C}$ for the gibbsite leaching for 1 hour and then the simulant was filtered using a Whatman ${ }^{\circledR 5} 1.0$ - $\mu \mathrm{m}$ glass fiber filter. A sample of the filtrate was taken for

\footnotetext{
${ }^{5}$ Whatman is a registered trademark of the Whatman Paper Limited Company, Kent, England.
} 
chemical analyses. The filtrate was kept at $90^{\circ} \mathrm{C}$, and $17.30 \mathrm{~g}$ of Li-hydroxide monohydrate was added as a $10 \mathrm{wt} \%$ solution ${ }^{6}$. After 4 hours, the solution was cooled to $65^{\circ} \mathrm{C}$ and filtered again using a Whatman ${ }^{\circledR} 1.0-\mu \mathrm{m}$ glass fiber filter. The $1 \mathrm{~L}$ of filtrate was a clear yellow solution and was sampled for chemical analyses. The filter cake was washed four times with $1 \mathrm{~L}$ of deionized (D.I.) water per wash (1:1 ratio filtrate to wash water), and then weighed.

\subsection{SINGLE-SHELL TANK SIMULANT - INITIAL TEST}

The second test run involved the SST simulant, which was prepared as shown in Table 2.

Table 2. Single-Shell Tank Simulant Chemical Makeup (1-L Batch).

\begin{tabular}{|l|r|r|c|}
\hline \multicolumn{1}{|c|}{ Reagent } & MW & \multicolumn{1}{c|}{$\begin{array}{c}\text { Weight } \\
\text { [g] }\end{array}$} & Amount [mol] \\
\hline $\mathrm{NaOH}$ & 40.0 & 85.27 & 2.13 \\
\hline $\mathrm{Na}_{2} \mathrm{CO}_{3}$ & 106.0 & 61.48 & 0.58 \\
\hline $\mathrm{Na}_{2} \mathrm{C}_{2} \mathrm{O}_{4}$ & 134.0 & 1.34 & 0.01 \\
\hline $\mathrm{KNO}_{3}$ & 101.0 & 3.03 & 0.03 \\
\hline $\mathrm{NaNO}_{3}$ & 85.0 & 328.95 & 3.87 \\
\hline $\mathrm{NaNO}_{2}$ & 69.0 & 56.58 & 0.82 \\
\hline $\mathrm{Na}_{2} \mathrm{SO}_{4}$ & 142.0 & 19.88 & 0.14 \\
\hline $\mathrm{Na}_{3} \mathrm{PO}_{4} \cdot 12 \mathrm{H}_{2} \mathrm{O} \cdot 0.25 \mathrm{NaOH}$ & 390.1 & 15.60 & 0.04 \\
\hline $\mathrm{NaCl}_{\mathrm{NaF}}$ & 58.4 & 4.67 & 0.08 \\
\hline $\mathrm{Na}_{2} \mathrm{Cr}_{2} \mathrm{O}_{7} \cdot 2 \mathrm{H}_{2} \mathrm{O}$ & 42.0 & 0.63 & 0.02 \\
\hline $\mathrm{CsNO}_{3}{ }^{2}$ & 298.0 & 11.92 & 0.04 \\
\hline $\mathrm{Al}_{(\mathrm{OH}}{ }_{3}{ }^{\mathrm{O}}$ & 211.0 & 0.021 & 0.0001 \\
\hline
\end{tabular}

${ }^{a} \mathrm{Cs}$-nitrate was added as an aqueous solution of $210 \mathrm{mg}$ Cs-nitrate salt in $250 \mathrm{~mL}$ water.

${ }^{\mathrm{b}}$ Gibbsite was heat leached into the solution at $105^{\circ} \mathrm{C}$ for 1 hour.

The SST simulant was prepared in the same way as the DST simulant, accounting for the formulation differences. The test was run according to the flow chart in Figure 2. After addition of $6.79 \mathrm{~g}$ of $\mathrm{Li}$-hydroxide $(0.16 \mathrm{~mol})$, the solution was kept at $90{ }^{\circ} \mathrm{C}$. Due to time constraints, filtration was performed after 2 hours of ripening (instead of 4 hours as in the DST test) and produced $850 \mathrm{~mL}$ of filtrate. For each water wash, $850 \mathrm{~mL}$ D.I. water (1:1 ratio of filtrate to wash water) was used.

\footnotetext{
${ }^{6} 172.01 \mathrm{~mL}$ of $\mathrm{LiOH}$ solution $\left\{25.15 \mathrm{~g} \mathrm{LiOH} \mathrm{H} \mathrm{H}_{2} \mathrm{O}\right.$ (mol. weight $41.96 \mathrm{~g} / \mathrm{mol}$ ) in $250 \mathrm{~mL}$ water $\}=0.41 \mathrm{~mol} \mathrm{Li}$.
} 


\subsection{SINGLE-SHELL TANK SIMULANT - RETEST}

Due to the unexpected results of the initial SST test (see section 4.2), the decision was made to run an additional test with the SST simulant. The SST retest was designed to address the Lithium demand for producing Li-hydrotalcite.

The test matrix for the retests was set for adding the equivalents of $0.2 \mathrm{M}, 0.3 \mathrm{M}$, and $0.4 \mathrm{M} \mathrm{Li}$ to $330 \mathrm{~mL}$ aliquots; this corresponds to a $\mathrm{Li}: \mathrm{Al}$ ratio of $1: 2,3: 4$, and $1: 1$ respectively. The three solutions will henceforth be referred to as $0.2-\mathrm{M} \mathrm{Li}, 0.3-\mathrm{M} \mathrm{Li}$, and $0.4-\mathrm{M} \mathrm{Li}$.

Another 1-L batch of the SST simulant was prepared as described in chapter 3.2 (see Table 2), and $31.21 \mathrm{~g}(0.40 \mathrm{~mol})$ of gibbsite heat was leached into the solution. Three aliquots of $300 \mathrm{~mL}$ of the supernate were staged in three $500-\mathrm{mL}$ beakers. Li-hydroxide was added ${ }^{7}$ and the solution was stirred at $90^{\circ} \mathrm{C}$ for 4 hours. After 30 minutes, the products were filtered and a sample of each filter cake was taken for SEM analysis. Since the amount of filterable material after 30 minutes was very low, the samples were insufficient for an XRD preparation. After 4 hours, the products were filtered again and the three filter cakes were washed four times each with $330 \mathrm{~mL}$ of D.I. water. The filtration and water washes were performed in a Millipore ${ }^{8}$ filter holder with clamp, using a $1.0-\mu \mathrm{m}$ Whatman ${ }^{\circledR}$ glass fiber filter, thus allowing much easier removal of the filter cake afterwards. The washed filter cakes were weighed.

Due to limited funding at the time of the retest experiments, no samples of the filter cake were submitted for chemical analyses for the SST rerun. Physical analyses of the solids were performed using XRD and SEM. Any variations in product quality (size, optical appearance, chemical composition) caused by ripening time could be traced with the SEM results.

\footnotetext{
7 '0.2 M Li': $2.63 \mathrm{~g} \mathrm{LiOH} . \mathrm{H}_{2} \mathrm{O}=>321 \mathrm{~mL}$ supernate + LiOH solution $(0.20 \mathrm{M} \mathrm{Li})$; '0.3 M Li': $3.94 \mathrm{~g} \mathrm{LiOH.H}$ O $=>$ $332 \mathrm{~mL}$ solution $(0.28 \mathrm{M} \mathrm{Li})$; ' $0.4 \mathrm{M} \mathrm{Li}^{\prime}: 5.26 \mathrm{~g} \mathrm{LiOH.H} \mathrm{H}_{2} \mathrm{O}=>342 \mathrm{~mL}$ solution $(0.37 \mathrm{M} \mathrm{Li})$.

${ }^{8}$ Millipore is a registered trademark of the Millipore Filter Corporation, Bedford, Massachusetts.
} 


\subsection{RESULTS AND DISCUSSION}

The results are presented in the order outlined in Section 3. Appendix B contains the compilation of final analytical results. In order to verify the amounts of $\mathrm{PO}_{4}$ and $\mathrm{SO}_{4}$ from the IC analyses, phosphorous and sulfur were added to the list of analytes in a rerun of ICP-AES analysis.

\subsection{DOUBLE-SHELL TANK SIMULANT}

Filtration of the gibbsite leach produced a clear yellow supernate. The comparison of the mixed supernate and the analysis of the actual supernate is shown in Table 3 . The increase in carbonate is most likely due to the one hour heat leaching of the gibbsite. The reduction in hydroxide can be attributed to the $\mathrm{OH}$ used by the dissolution of gibbsite to the $\mathrm{Al}(\mathrm{OH})_{4}$-ion.

Table 3. Comparison of Amounts Used in Supernate Preparation and Amounts Analyzed After Gibbsite Leaching and Filtration.

\begin{tabular}{|c|ccc|}
\hline DST & $\begin{array}{c}\text { Added } \\
{[\text { mol] }}\end{array}$ & $\begin{array}{c}\text { Analyzed } \\
{[\text { mol] }}\end{array}$ & $\begin{array}{c}\text { Difference } \\
{[\text { mol] }}\end{array}$ \\
\hline Al & 0.80 & 0.91 & -0.11 \\
Cs & 0.0005 & 0.0006 & -0.0001 \\
\hline NO3 & 1.11 & 1.03 & 0.07 \\
NO2 & 1.15 & 1.08 & 0.07 \\
Ox & 0.0003 & n.d. & - \\
CO3 & 0.06 & 1.79 & -1.73 \\
OH & 2.20 & 1.69 & 0.52 \\
F & 0.01 & 0.01 & 0.002 \\
Cl & 0.12 & 0.11 & 0.005 \\
\hline P & 0.01 & 0.01 & 0.00 \\
PO4 & 0.01 & 0.02 & -0.01 \\
\hline S & 0.01 & 0.01 & 0.00 \\
SO4 & 0.01 & 0.01 & 0.00 \\
\hline
\end{tabular}

Added = amounts from Table 1; Analyzed = amounts based on results in Appendix B. n.a. ... not analyzed; n.d. ... not determined (below detection limit)

Addition of Li-hydroxide caused a reaction in less than 2 minutes with white particulate flocculating in the beaker. During the 4 hours of crystal ripening at $90^{\circ} \mathrm{C}$, the solution turned milky white (see Figure 3 ). The solution filtered quickly $(\sim 1 \mathrm{~min}$ ) and produced an off-white filter cake. Four washing steps of the filter cake produced a bright white fluffy product of highly crystalline material (see Figure 4).

The filtrate was clear and showed no visible signs of unfiltered solids. A compilation of aliquots of the filtrate and four washes from the DST experiment is displayed in Figure 5. The most important observation in Figure 5 is the lack of coloration in the $2^{\text {nd }}$ to $4^{\text {th }}$ water washes. 
Figure 3. Double-Shell Tank Simulant Product after Four Hours of Ripening and Unwashed Filter Cake.
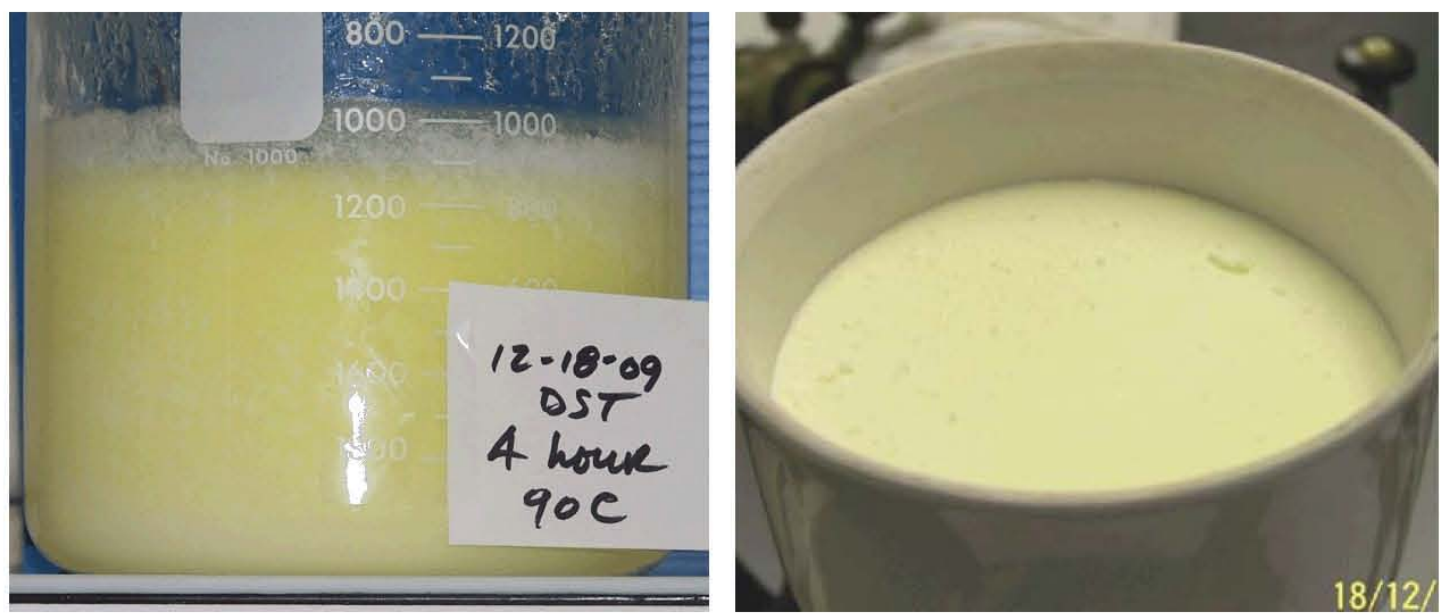

Figure 4. Final Water-Washed Filter Cake from Double-Shell Tank Simulant.

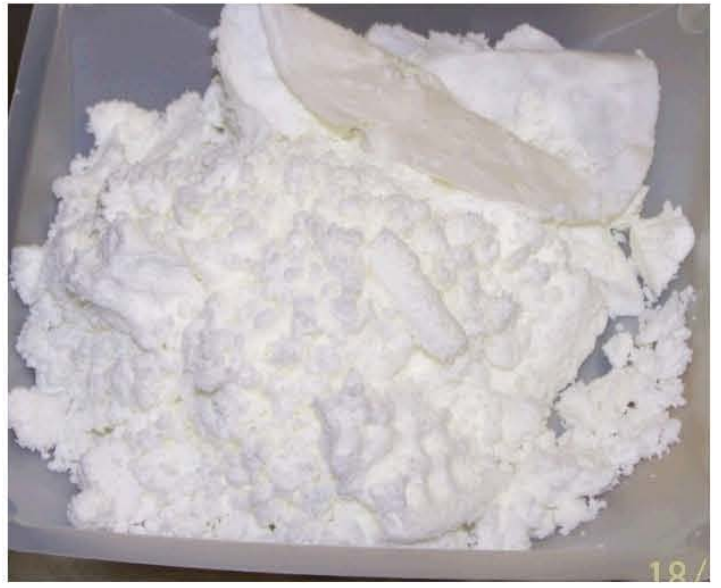

Figure 5. Comparison of Aliquots of the Filtrate and Wash Filtrates from Double-Shell Tank Simulant Filter Cake.

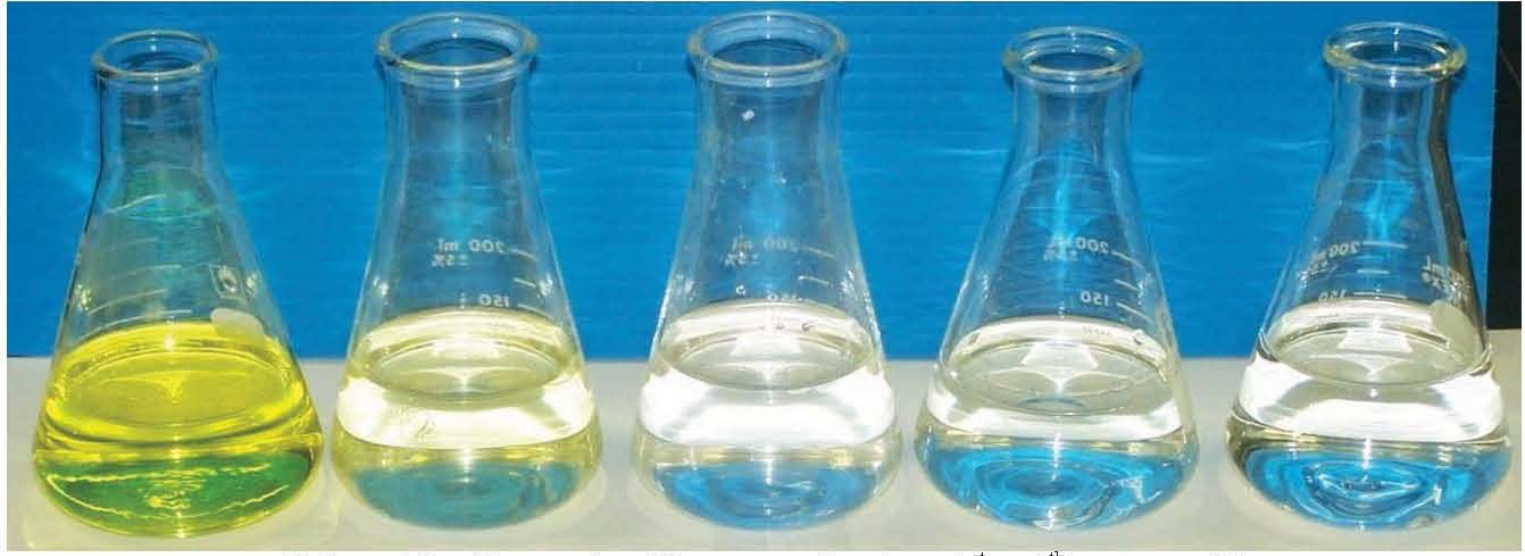

(left to right: filtrate after 4 hours reaction time, $1^{\text {st }}$ to $4^{\text {th }}$ water wash) 
The wet filtercake mass was $130.6 \mathrm{~g}$. Based on the TGA analysis of $66.2 \mathrm{wt} \%$ water in the filter cake, this is equivalent to a calculated dry weight of $44.1 \mathrm{~g}$. However, as described in the summary section, the actual dry weight is more likely to be $114.6 \mathrm{~g}$ (containing $102 \mathrm{of} \mathrm{Li}$ hydrotalcite), suggesting that the TGA analyses also included the release of intercalated carbonate.

Table 4. Comparison of Selected Analytes in Filtrates and Wash Filtrates of Double-Shell Tank Supernate.

\begin{tabular}{|l|cccccccc|c|}
\hline [mol\%] $^{\mathrm{a}}$ & $\mathbf{A l}$ & $\mathbf{L i}$ & $\mathbf{T I C}$ & $\mathbf{P}$ & $\mathbf{N O}_{3}$ & $\mathbf{N O}_{\mathbf{2}}$ & $\mathbf{O H}^{\mathbf{c}}$ & $\mathbf{S}$ & ${ }^{133} \mathbf{C s}$ \\
\hline Filtrate & 5.72 & 4.08 & 0.08 & 3.59 & 79.2 & 78.0 & 87.7 & 100 & 76.8 \\
Wash 1 & 2.07 & 2.05 & 0.03 & $<0.4$ & 6.38 & 6.56 & 8.14 & 5.93 & 6.40 \\
Wash 2 & 0.11 & 0.26 & 0.01 & 0.06 & 0.06 & 0.05 & 0.16 & $<0.01$ & 0.05 \\
Wash 3 & 0.04 & 0.15 & 0.01 & 0.06 & 0.04 & 0.04 & 0.08 & 0.39 & 0.02 \\
Wash 4 & 0.04 & 0.15 & $<0.01$ & 0.77 & 0.03 & 0.03 & 0.08 & 0.54 & 0.02 \\
\hline Filter Cake $^{b}$ & 92.0 & 93.3 & 99.9 & 95.5 & 14.3 & 15.3 & 3.86 & n.r. & 16.7 \\
\hline
\end{tabular}

${ }^{a} \mathrm{Mol} \%$ are normalized to supernate composition; calculations were based on analytical data in Appendix B; amount of filtrate was $650 \mathrm{~mL}$, washes 1 to 4 were $1000 \mathrm{~mL}$ each.

${ }^{\mathrm{b}}$ The quantities of filter cake were calculated from the difference between the supernate (= "Analyzed" in Table 3) and the sum of filtrate (after Li-addition) plus washes 1 to 4 ; in case the calculated amount was negative, 'n.r.'(= not retained) was used as classifier.

${ }^{\mathrm{c}}$ Takes the $\mathrm{OH}$-contribution from the $\mathrm{LiOH}$-addition into account.

Table 4 and Figures 6 and 7 compare the amounts of ions in the filtrate and in the water washes. All data are normalized to the supernate (i.e., simulant recipe plus gibbsite leaching). After the $1^{\text {st }}$ water wash, $<1 \mathrm{~mol} \%$ of the removable ions were left on the filter cake.

Figure 6. Comparison of Mol\% of Selected Analytes in Filtrates from Double-Shell Tank Simulant.

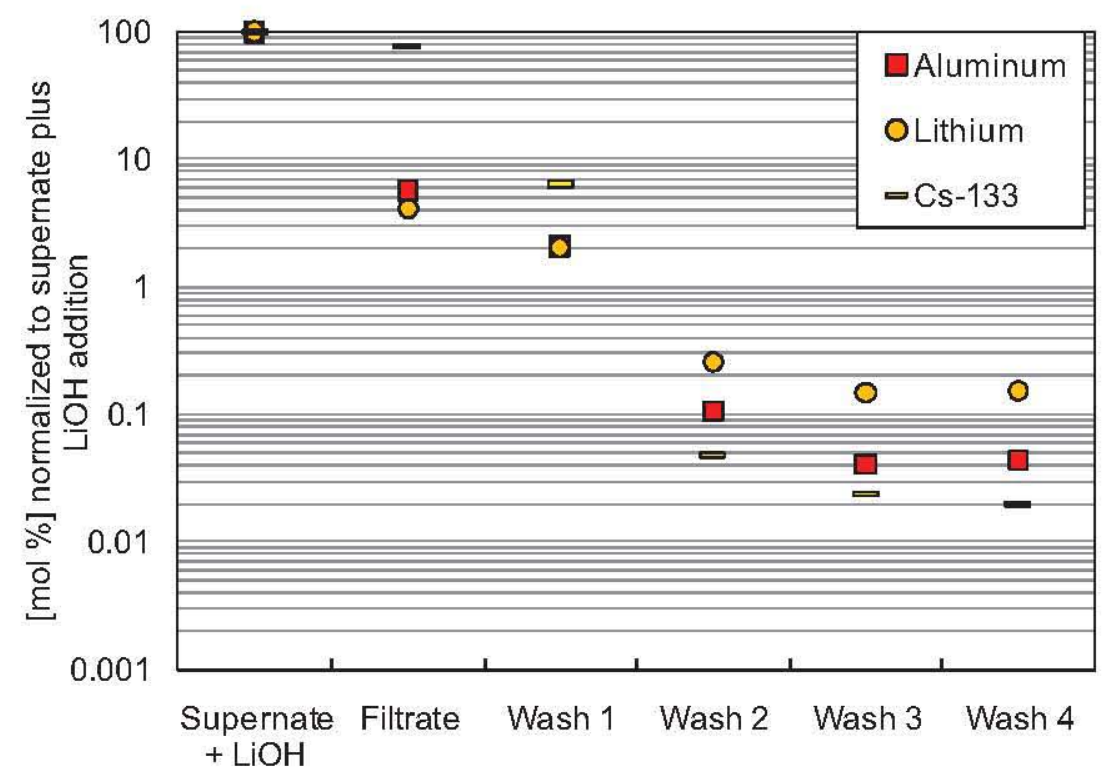


The phosphorus distribution showed an interesting increase for the $4^{\text {th }}$ wash. Before drawing any conclusions on the retention of phosphorus in the hydrotalcite, the results need to be closely examined. There is no trend established, since the results of the filtrate, wash 2, and wash 3 are estimated values indicating the data were within the 10 times (defined as the limit of quantification) of the detection limit. As previously mentioned, phosphate was additionally measured using the IC. In this case, the results for the filtrate, wash 1, and wash 2 were below the detection limit, and wash 4 was about 5 times larger than wash 3 . In summary, the reason for the increase of the phosphorus concentration in the final wash cannot be derived from these analyses.

\section{Figure 7. Comparison of Mol\% of Selected Analytes in Filtrates from Double-Shell Tank Simulant.}

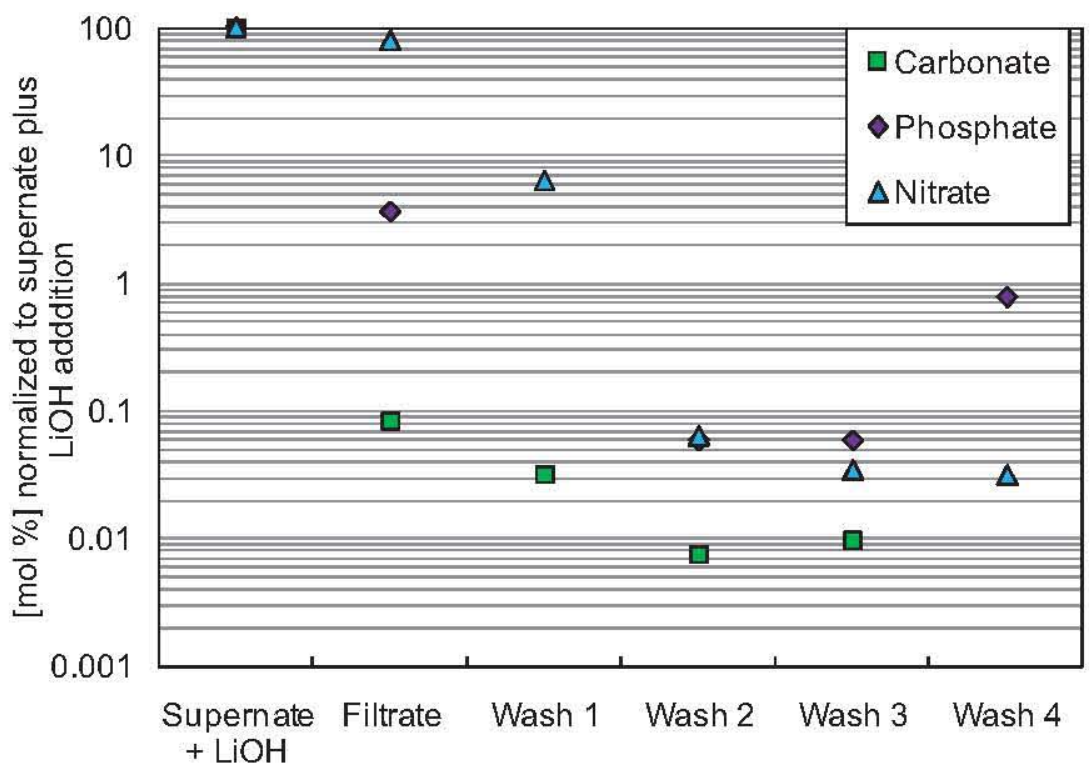

One of the concerns about the precipitation of the hydrotalcite is whether or not radionuclides within Hanford waste would co-precipitate and could be removed by washing the filter cake. The test runs included ${ }^{133} \mathrm{Cs}$ in the simulant composition. In order to avoid issues with the detection limit of cesium, the amount was approximately 100 -fold the concentration of ${ }^{137} \mathrm{Cs}$ found in the tanks.

From the ease with which the cesium was able to be washed from the product, the cesium appears not to be incorporated into the structure of the hydrotalcite; however, $\sim 17 \mathrm{~mol} \%$ of $\mathrm{Cs}$ is retained in the filter cake. At the calculated retained molarity (see Table 4), and two orders of magnitude increased concentration versus actual DST supernate, the mass of ${ }^{133} \mathrm{Cs}$ retained in the filter cake would be $0.124 \mathrm{mg}$. Assuming that the ${ }^{133} \mathrm{Cs}$ would behave as ${ }^{137} \mathrm{Cs}$ and the specific activity of ${ }^{137} \mathrm{Cs}$ is $87 \mathrm{Ci} / \mathrm{g}$, then $10.8 \mathrm{mCi} \mathrm{Cs}$ is retained in the filter cake. With a mass of $102 \mathrm{~g}$ for the Li-hydrotalcite ${ }^{9}$, the input of ${ }^{137} \mathrm{Cs}$ would yield $106 \mu \mathrm{Ci} / \mathrm{g}$ in the dry Li-hydrotalcite.

\footnotetext{
${ }^{9}$ See calculation in chapter "Summary and Recommendations."
} 
Subsamples of the filtercake were used for the physical analyses, by PLM, SEM, and XRD to identify the mineralogy and chemistry of the cake product. The PLM image in Figure 8 shows clusters of material. Due to the preparation of the slide with a cover slip, any spherical agglomerates are flattened. However, the individual crystallites are clearly visible. This indicates that the product is stable, but soft and easily compactable.

Figure 8. Polarized Light Microscopy Image of Double-Shell Tank Simulated Filter Cake.

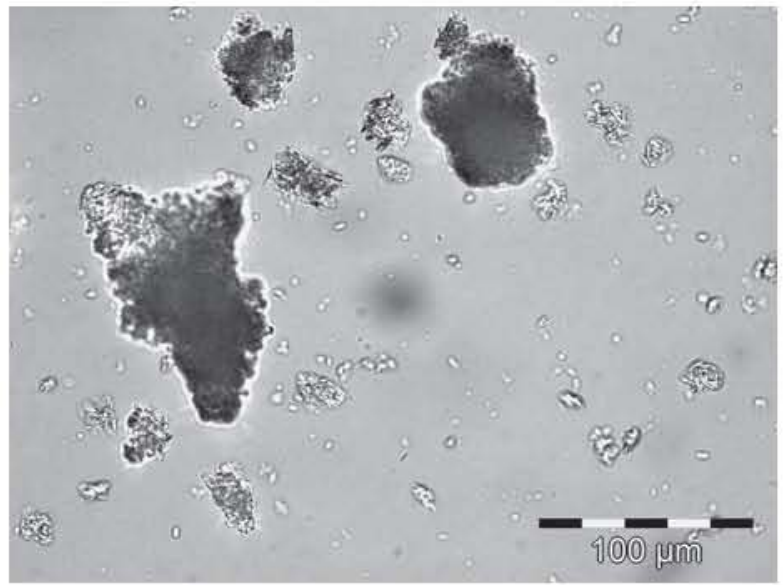

Typical agglomerates found in the DST LiHT product are displayed in the Back Scattered Electron (BSE) images of Figures 9 and 10. The agglomerates reach about $50 \mu \mathrm{m}$ in diameter and are made of very thin platelets $(\sim 1 \mu \mathrm{m})$ of about $5-10 \mu \mathrm{m}$ diameter. This structure is in agreement with the theoretical structure shown in Figure 1. The overview in Figure 10 (top left image) shows the size distribution of particles on the SEM preparation slide. The particle in close-up is one of the larger specimens. The Energy Dispersive Spectrometry (EDS) spectra of the platelets in Figures 9 and 10 identify an Al-rich phase with a minor P-peak, which is consistent with Li-hydrotalcite ${ }^{10}$.

\footnotetext{
${ }^{10}$ The atomic number of lithium is too low to be detected in an EDS. The C peak is not indicative for carbonate since it is primarily due to the carbon coating applied during the SEM specimen preparation. Whether the phosphorus is intercalated in the Li-hydrotalcite or surficially attached could not be determined.
} 
Figure 9. Back Scattered Electron Image and Energy Dispersive Spectrometry Spectrum of Double-Shell Tank Filter Cake Product.
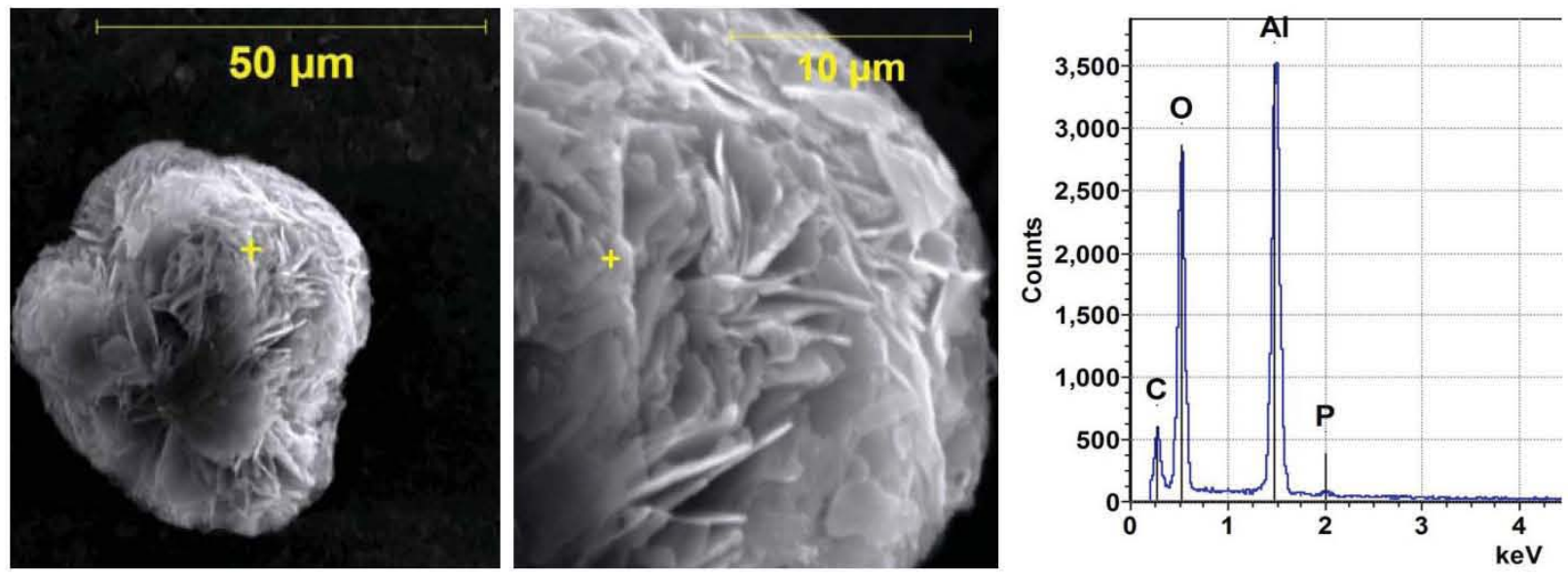

Figure 10. Back Scattered Electron Image and Energy Dispersive Spectrometry Spectrum of Double-Shell Tank Simulant Filter Cake.
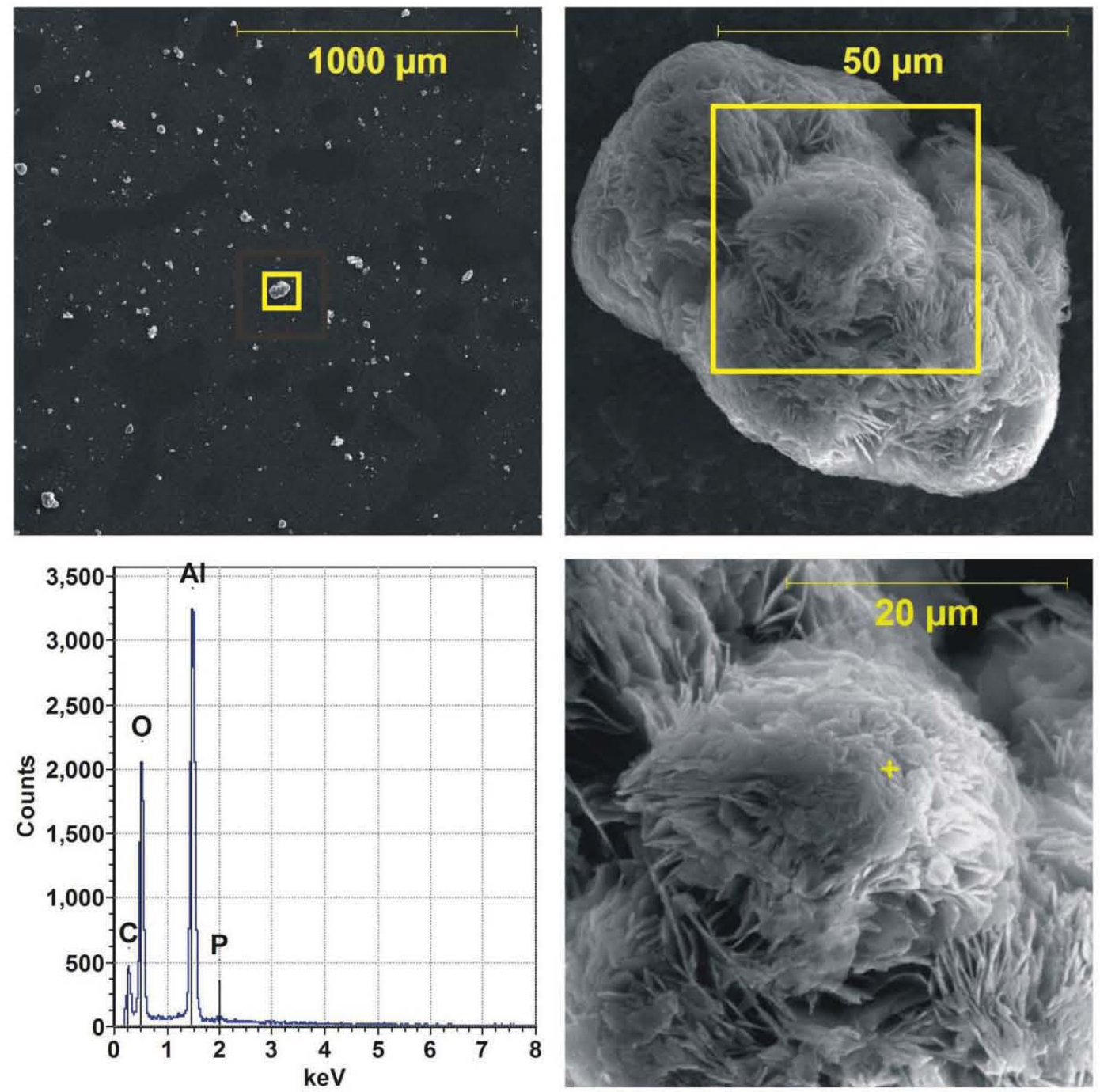
Based on the appearance in Figures 9 and 10, a three-step formation seems to be likely. First the platelets form, then the primary spherical objects, and finally the particulates as found in the filter cake. Whether these stages are distinctly separate from each other or a continuous formation takes place is not known to date. However, for future investigations this aspect might be a crucial step, since all that is necessary for the process to work is a filterable product (i.e., the formation of the platelets).

The XRD spectrum in Figure 11 reveals the structural nature and composition of the particulates. Comparison to the reference spectra shows the filter cake is entirely made of Li-hydrotalcite in the carbonate form. Only traces of sodium nitrate $\left(\mathrm{NaNO}_{3}\right)$ were found as an additional phase.

Thermo-gravimetric analysis was used to determine the percentage water of the filter cake (Figure 12). The inflection point in the spectrum at $110^{\circ} \mathrm{C}$ (in a duplicate analysis at $120^{\circ} \mathrm{C}$ ) is indicative of the release of the intercalated water. 
Figure 11. X-Ray Diffractogram of Double-Shell Tank Simulant Filter Cake.

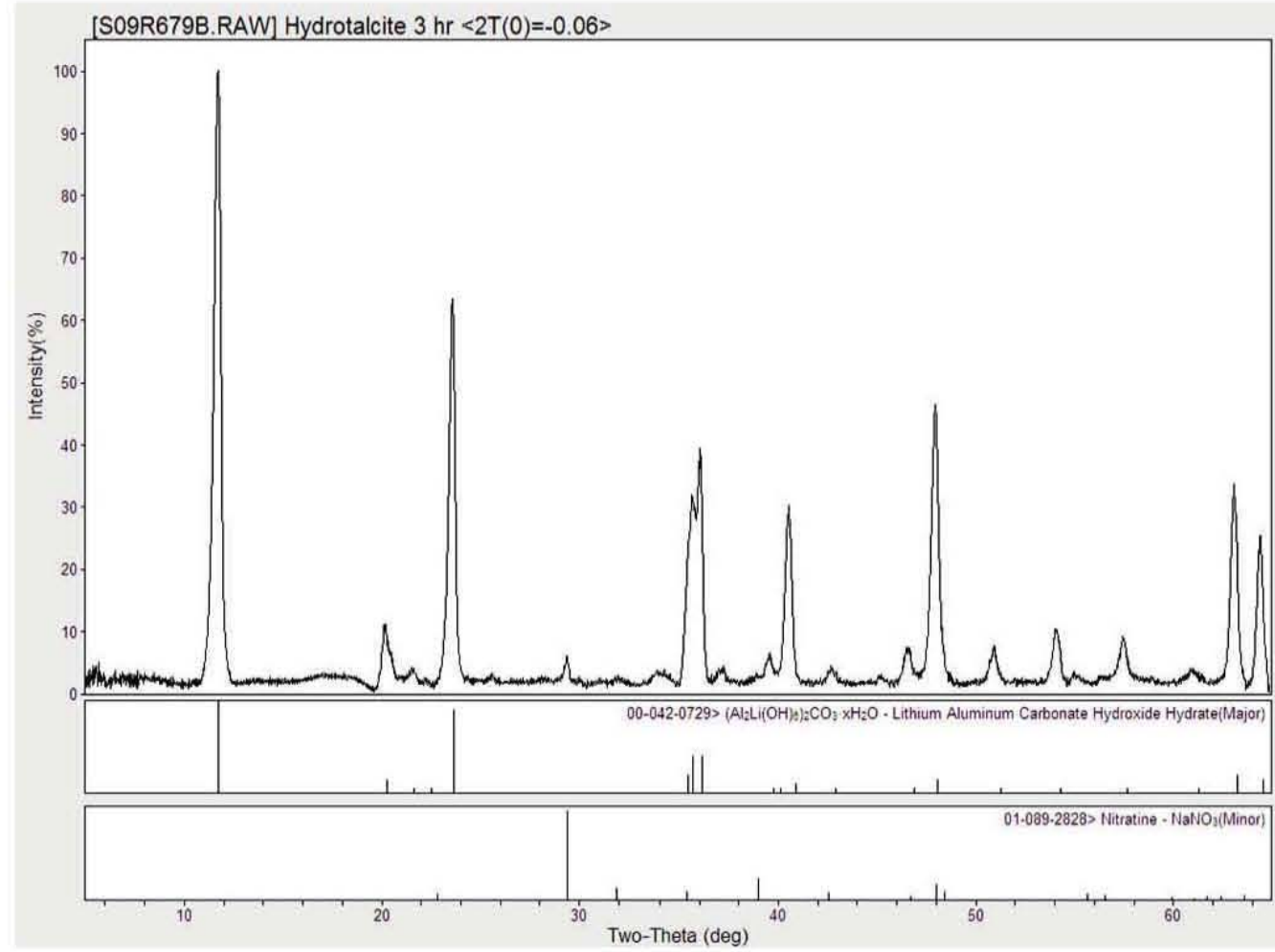

Figure 12. Thermal Gravimetric Analysis Spectrum of Double-Shell Tank Simulant Filter Cake.

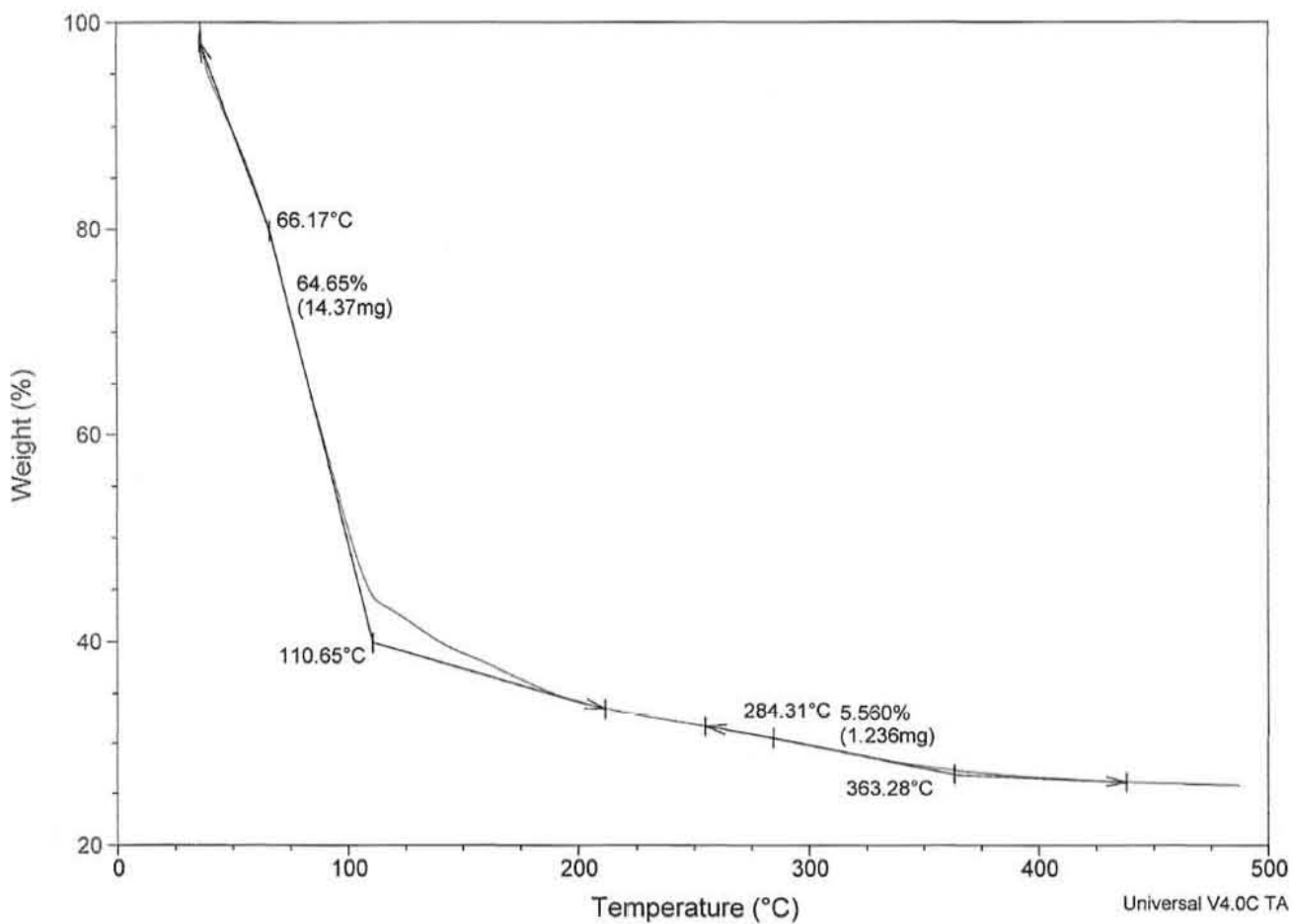




\subsection{SINGLE-SHELL TANK SIMULANT - INITIAL TEST}

The comparison between the simulant composition (before gibbsite leaching) and the supernate composition ("analyzed" = after gibbsite leaching) is shown in Table 5. After Li-hydroxide addition, an instantaneous reaction was observed with a white product flocculating in the beaker. Within 1 minute, the beaker was entirely opaque. Over the next 2 hours of crystal ripening, the general appearance did not change much. The product after 2 hours of crystal ripening is shown in Figure 13.

Table 5. Comparison of Amounts Used in Supernate Preparation and Amounts Analyzed After Gibbsite Leaching and Filtration.

\begin{tabular}{|c|lll|}
\hline SST & $\begin{array}{c}\text { Added } \\
{[\mathbf{m o l}]}\end{array}$ & $\begin{array}{c}\text { Analyzed } \\
{[\mathbf{m o l}]}\end{array}$ & $\begin{array}{c}\text { Difference } \\
{[\mathrm{mol}]}\end{array}$ \\
\hline Al & 0.40 & 0.36 & 0.04 \\
Cs & 0.0001 & 0.0001 & 0.0000 \\
\hline NO3 & 3.90 & 3.08 & 0.82 \\
NO2 & 0.82 & 0.63 & 0.19 \\
Ox & 0.010 & 0.009 & 0.001 \\
CO3 & 0.58 & 0.10 & 0.48 \\
OH & 1.89 & 1.29 & 0.60 \\
F & 0.02 & 0.02 & -0.0008 \\
Cl & 0.08 & 0.06 & 0.02 \\
\hline P & 0.04 & 0.05 & -0.01 \\
PO4 & 0.04 & 0.05 & -0.01 \\
\hline S & 0.14 & 0.11 & 0.03 \\
SO4 & 0.14 & 0.14 & 0.00 \\
\hline
\end{tabular}

Added = amounts from Table 1; analyzed = amounts based on results in Appendix B. n.a. ... not analyzed; n.d. ... not determined (below detection limit)

Figure 13. Single-Shell Tank Simulant Product after Two Hours of Ripening and Washed Filter Cake.
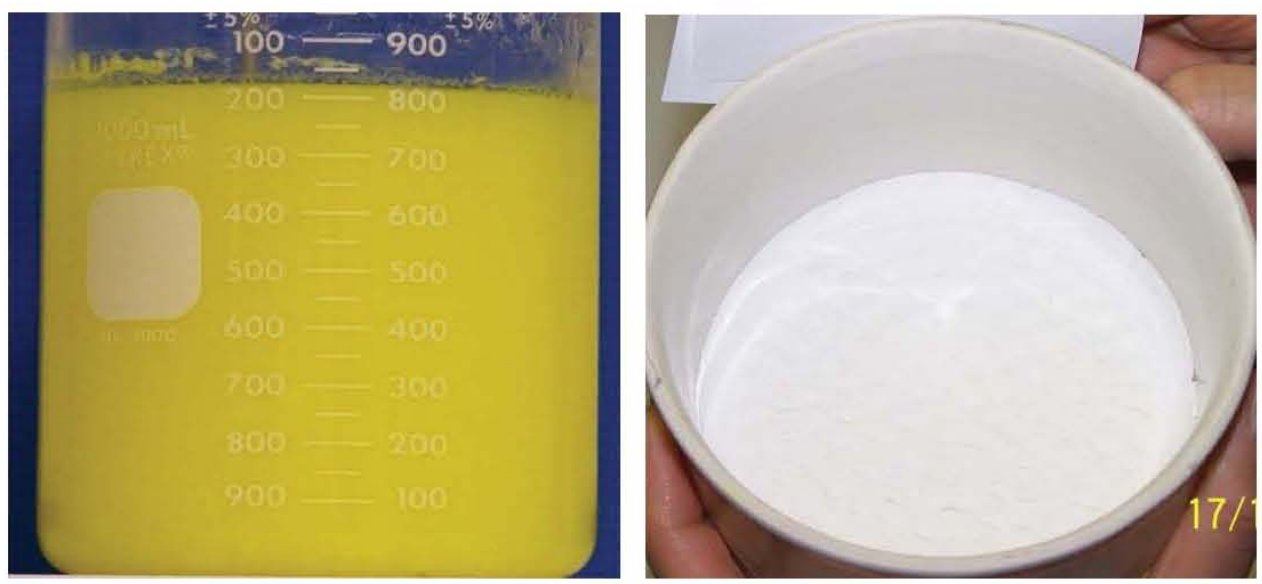
The washed filter cake consisted of white crystals. The wet mass was $7.84 \mathrm{~g}$ (dry mass $3.87 \mathrm{~g}$, based on TGA analysis). The product filtered quickly and produced an optically very clear filtrate. Turbidity measurements were not performed on this run, but were performed on the subsequent SST retests (see section 4.3). The setup in Figure 14 shows Erlenmeyer flasks with an aliquot of the filtrate and the four water washes. The extreme color change between filtrate, wash water 1 , and wash water 2 indicates that most of the $\mathrm{Cr}$ is washed out in the first step. As with the DST product, the wash processes released most of the water soluble ions in the first water wash.

Figure 14. Comparison of Aliquots of the Filtrate and Wash Filtrates from Single-Shell Tank Simulant Filter Cake.

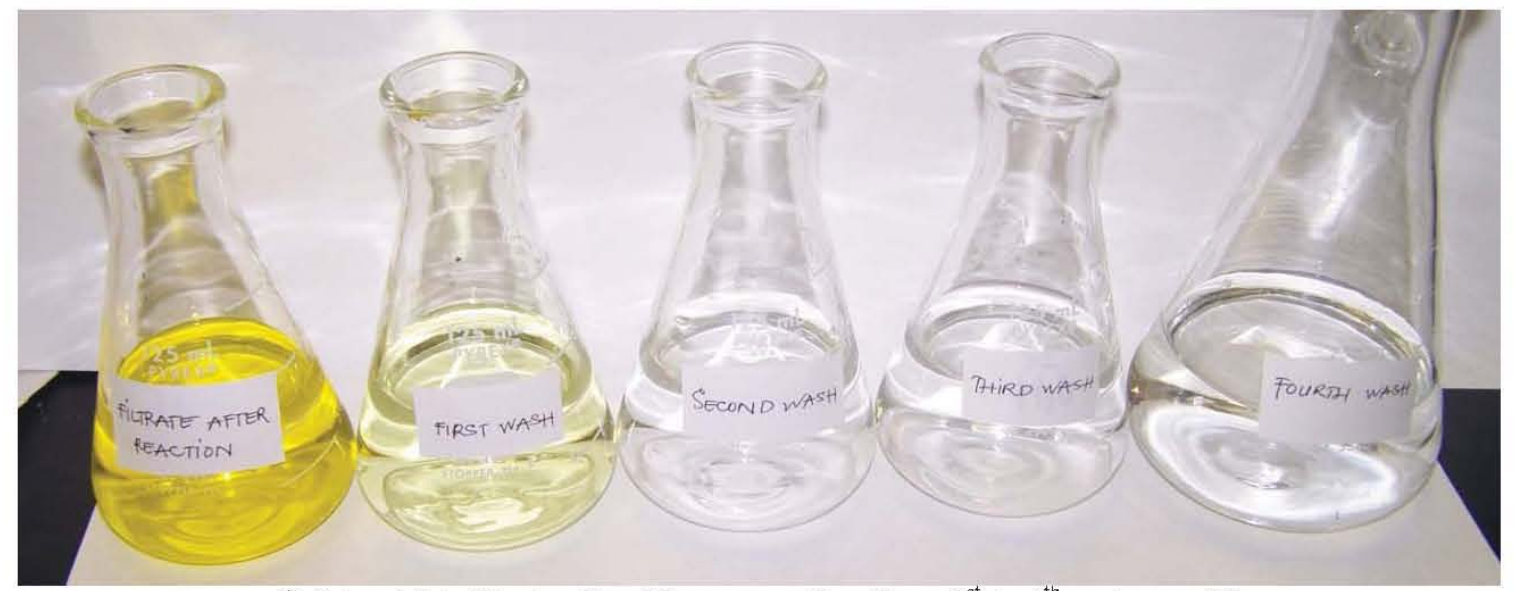

(left to right: filtrate after 4 hours reaction time, $1^{\text {st }}$ to $4^{\text {th }}$ water wash)

Table 6 and Figures 15 and 16 show the retention of analytes in the filtercake during the filtration and subsequent wash cycles for the SST supernate. In this case, all of the nitrate, nitrite, hydroxide sulfur, cesium, and most of the carbonate were found in the filtrate. Lithium formed $\mathrm{Li}_{3} \mathrm{PO}_{4}$ but not entirely; only $~ 87 \mathrm{~mol} \%$ of the available $\mathrm{Li}$ precipitated, of which 10 $\mathrm{mol} \%$ were water soluble during the washes.

Table 6. Comparison of Selected Analytes in Filtrates and Wash Filtrates of Single-Shell Tank Supernate.

\begin{tabular}{|l|cccccccc|c|}
\hline [mol\% $^{\text {a }}$ & $\mathbf{A l}$ & $\mathbf{L i}$ & $\mathbf{T I C}$ & $\mathbf{P}$ & $\mathbf{N O}_{\mathbf{3}}$ & $\mathbf{N O}_{\mathbf{2}}$ & $\mathbf{O H}^{\mathbf{c}}$ & $\mathbf{S}$ & ${ }^{{ }^{133}} \mathbf{C s}$ \\
\hline Filtrate & 91.7 & 14.2 & 96.3 & 8.98 & 104 & 102 & 103 & 101 & 101 \\
Wash 1 & 0.34 & 4.37 & 1.5 & 6.76 & 0.32 & 0.32 & 0.93 & 3.32 & 0.32 \\
Wash 2 & 0.008 & 1.98 & 0.2 & 2.92 & 0.002 & $<0.01$ & 0.31 & 0.02 & 0.002 \\
Wash 3 & 0.004 & 1.18 & 0.1 & 1.73 & 0.001 & $<0.01$ & $<0.01$ & 0.01 & 0.001 \\
Wash 4 & 0.003 & 1.01 & 0.2 & 1.28 & 0.001 & $<0.01$ & $<0.01$ & 0.44 & 0.001 \\
\hline Filtercake $^{\text {b }}$ & 7.91 & 77.3 & 1.7 & 78.3 & n.r. & n.r. & n.r. & n.r. & n.r. \\
\hline
\end{tabular}

${ }^{\mathrm{a}} \mathrm{Mol} \%$ are normalized to supernate composition; calculations were based on analytical data in Appendix B; amounts of filtrate and wash 1 to wash 4 were $850 \mathrm{~mL}$.

b Filter cake was calculated as the difference between supernate (= "Analyzed" in Table 5) and the sum of filtrate (after Li-addition) plus washes 1 to 4 ; in case the calculated amount was negative, 'n.r.' (= not retained) was used as classifier.

${ }^{\mathfrak{c}}$ Takes the $\mathrm{OH}-\mathrm{contribution}$ from the LiOH-addition into account. 
Figure 15. Comparison of Mol\% of Selected Analytes in Filtrates from Single-Shell Tank Supernate.

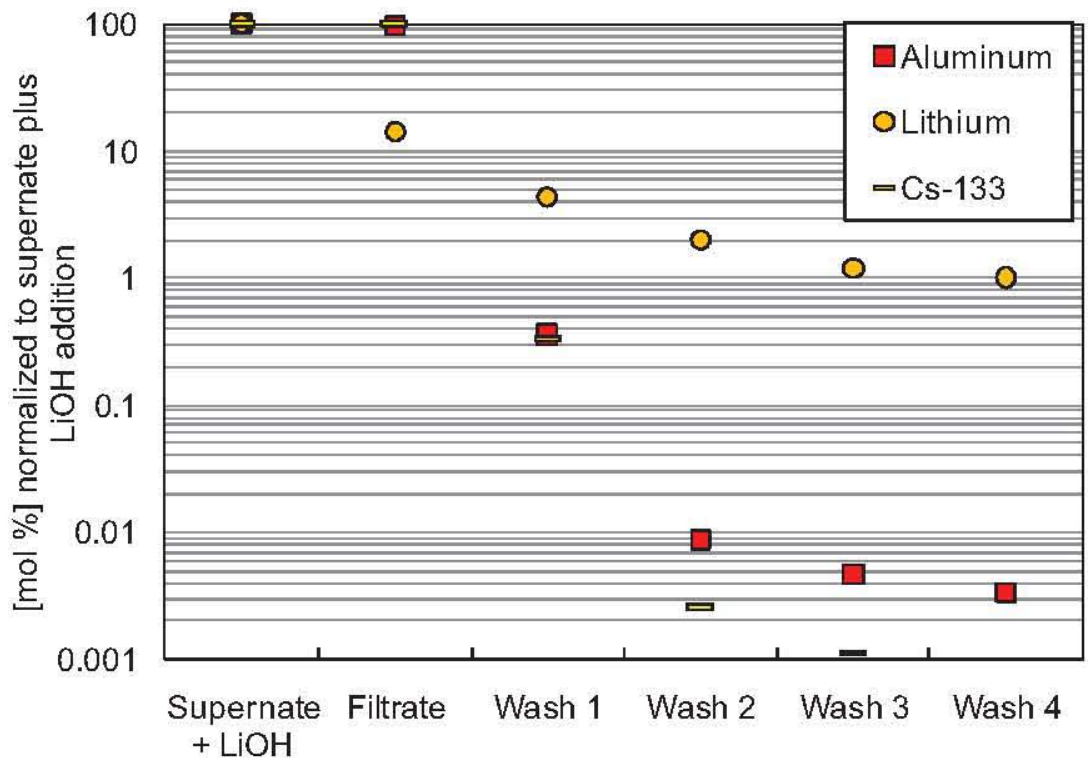

Figure 16. Comparison of Mol\% of Selected Analytes in Filtrates from Single-Shell Tank Supernate.

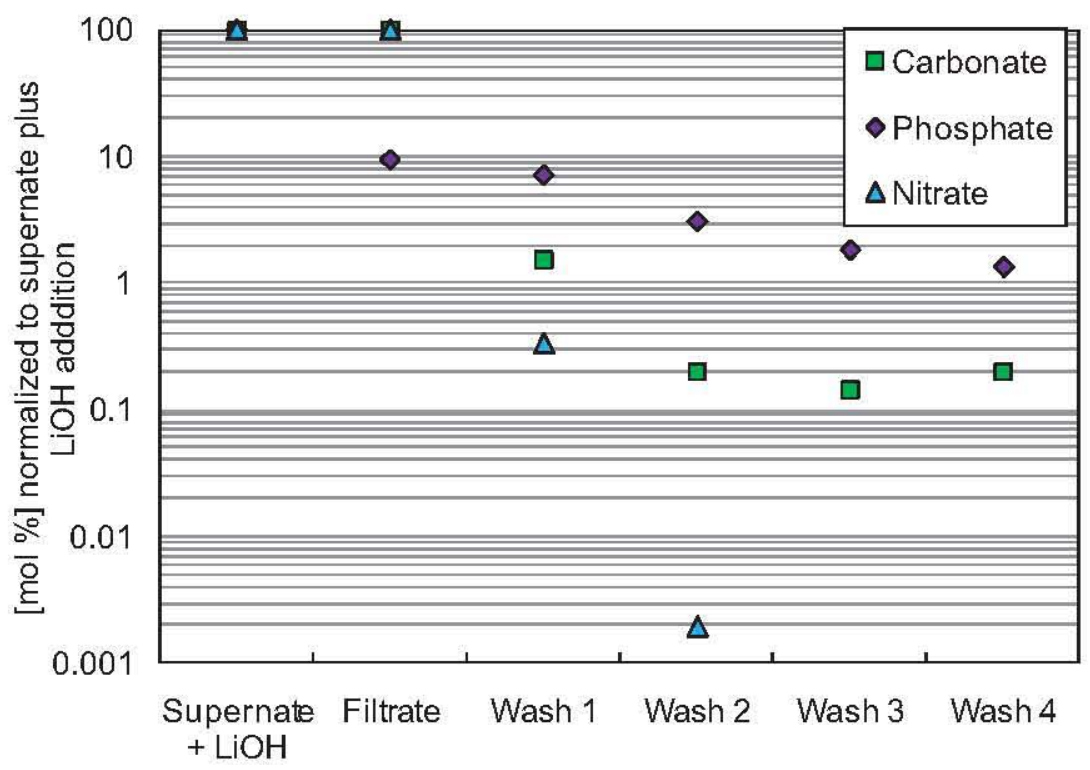

The white crystallites of the filter cake were analyzed with SEM, XRD and PLM to identify the phases involved. Special emphasis was placed on whether there was any evidence that Lihydrotalcite formed.

PLM analysis of the filter cake shows 1-2 $\mu \mathrm{m}$-sized crystals, round- to hexagon-shaped, but no large agglomerates are visible (Figure 17). 
Figure 17. Polarized Light Microscopy Image of the Single-Shell Tank Simulant Filter Cake.

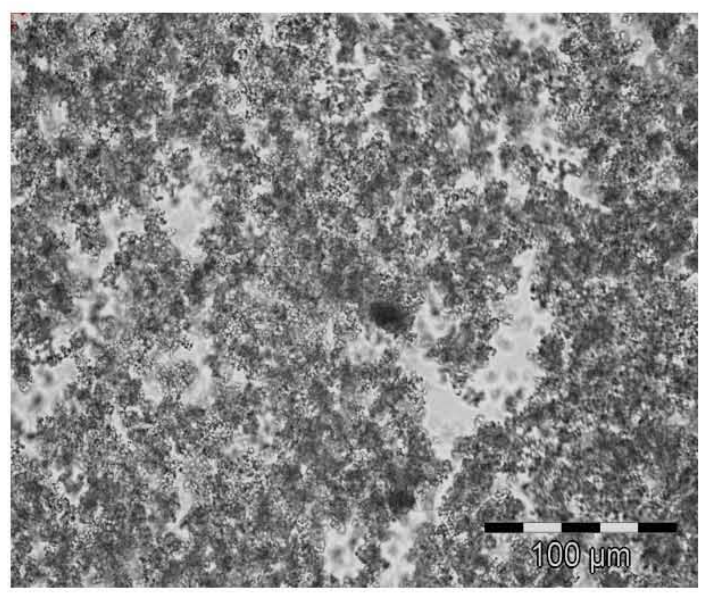

The BSE image and EDS spectrum in Figure 18 reveal the nature of the filter cake product. The crystals have a mixed composition of a $\mathrm{P}$-rich phase and some Na-Al-silicate. However, no sign of hydrotalcite could be observed, i.e., an aluminum-rich phase.

Figure 18. Back Scattered Electron Image and Energy Dispersive Spectrometry Spectrum of the Single-Shell Tank Simulant Filter Cake.
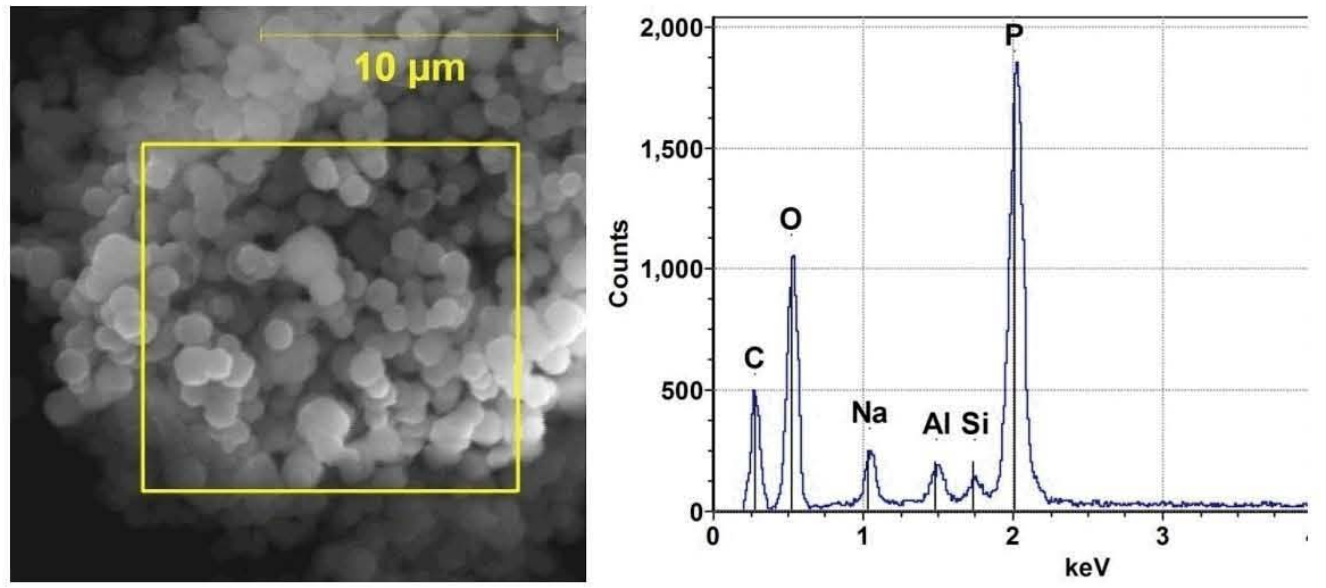

This result is further clarified by the XRD pattern shown in Figure 19. The two phases identified were Li-phosphate and the minor phase hydroxy cancrinite (Na-Al-silicate); the latter is most likely an artifact from the dissolution of Si out of the glass beaker. No traces of hydrotalcite could be determined. 
Figure 19. X-Ray Diffractogram of the Single-Shell Tank Filter Cake Product.

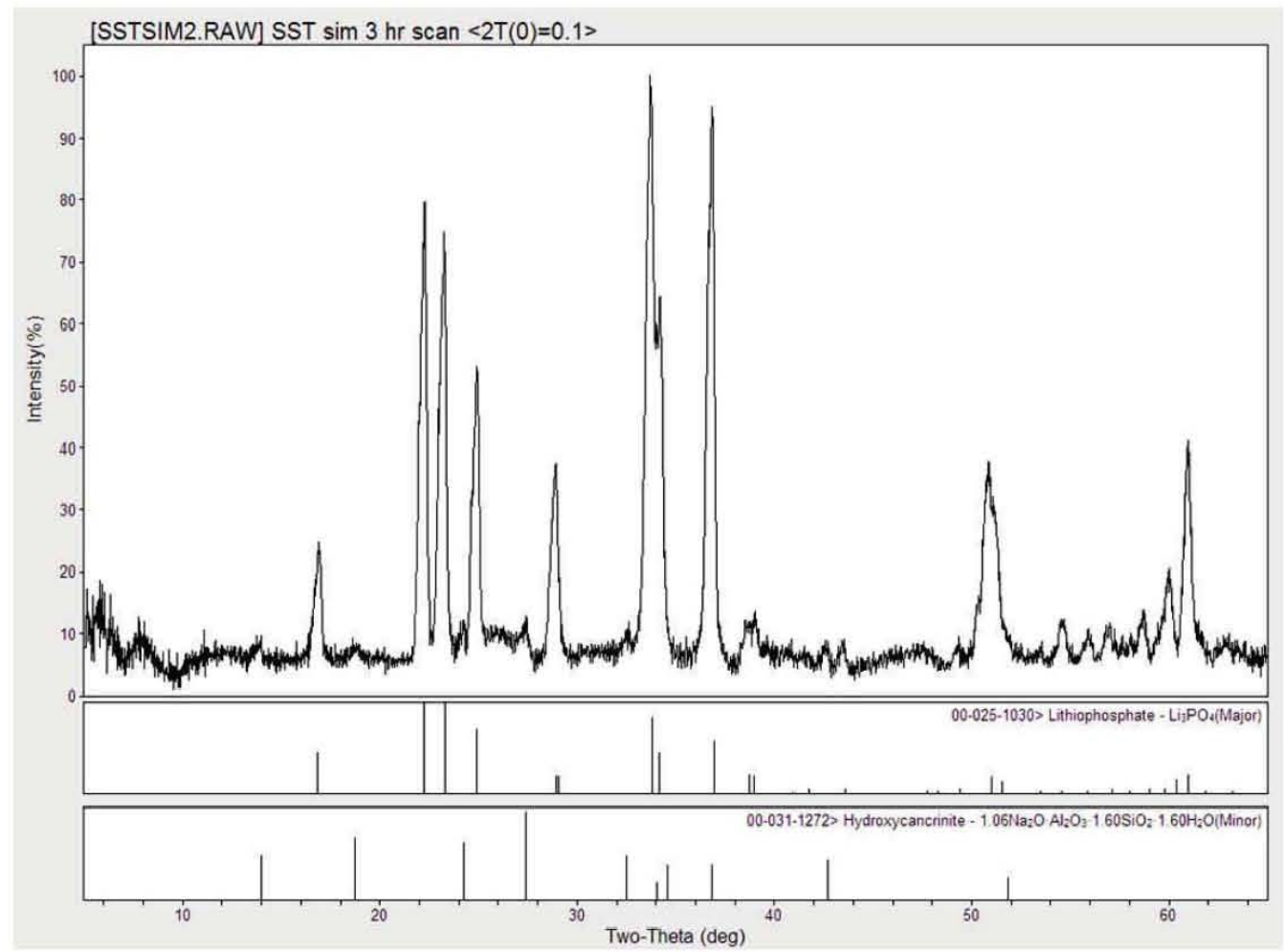

\subsection{SINGLE-SHELL TANK SIMULANT - RETEST}

Addition of the different amounts of Li showed slight visual differences in reaction kinetics. The 0.2-M Li-containing beaker immediately formed white crystallites as in the previous SST run. However, the reaction in the other two beakers was delayed by about 15 to 20 seconds. After 4 hours of crystal ripening, the three beakers had the same appearance (see Figure 20).

Figure 20. Single-Shell Tank Simulant Retest Product after Four Hours of Ripening.

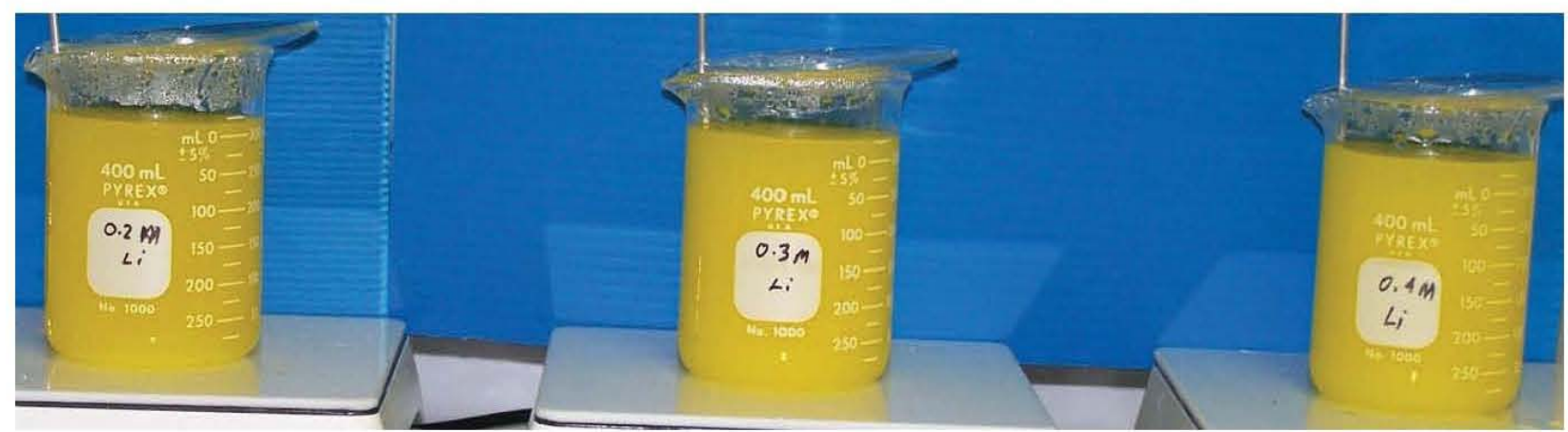

The three different products behaved differently during filtration: the $0.2-\mathrm{M}$ Li-product stuck to the sidewalls of the beaker but filtered rapidly. The $0.3-\mathrm{M} \mathrm{Li}$ product had no material sticking to the sides, the filter cake had a smoother look, and the filtrate started foaming during the 
filtration. The 0.4-M Li-product behaved like the 0.3-M Li; however, the filtrate was much clearer.

In Table 7, the significantly different amounts of filter cake and associated filtrate turbidities are compared to the actual amounts of $\mathrm{Li}, \mathrm{Al}$, and $\mathrm{P}$ added to each beaker. It can be seen that the excess $\mathrm{Li}$ reaction $(0.4 \mathrm{M} \mathrm{Li})$ produced the largest amount of filter cake and the clearest filtrate (Table 7 NTU values). In contrast, the $0.2-\mathrm{M} \mathrm{Li}$ filter cake had the lowest mass, even lower than the SST original experiment ${ }^{11}$. No explanation has been found to date, although one possibility may be that the extended reaction time in the SST retest ( 4 hours versus 2 hours) caused the product breakdown. Figure 21 shows the filter cakes after the four wash cycles for each case.

Table 7. Comparison of Yield and Turbidity with Lithium, Aluminum and Phosphorus Concentrations for the Single-Shell Tank Simulant Retests.

\begin{tabular}{|c|ccc|}
\hline Sample & $\mathbf{0 . 2} \mathbf{~ M ~ L i}$ & $\mathbf{0 . 3} \mathbf{~ M ~ L i}$ & $\mathbf{0 . 4} \mathbf{~ M ~ L i}$ \\
\hline $\mathrm{Li}[\mathrm{mol}]^{\mathrm{a}}$ & 0.063 & 0.094 & 0.125 \\
$\mathrm{Al}[\mathrm{mol}]^{\mathrm{a}}$ & 0.12 & 0.12 & 0.12 \\
$\mathrm{P}[\mathrm{mol}]^{\mathrm{a}}$ & 0.012 & 0.012 & 0.012 \\
\hline${\text { Filtrate turbidity }[\mathrm{NTU}]^{\mathrm{b}}}^{\mathrm{b}}$ & 6.0 & 3.1 & 0.6 \\
\hline Filter cake weight $[\mathrm{g}]$ & 0.24 & 3.33 & 3.47 \\
\hline
\end{tabular}

${ }^{\text {a }}$ Actual moles added to each of the $300 \mathrm{~mL}$ aliquots.

${ }^{\mathrm{b}}$ Compared to distilled water with a turbidity measurement of 0.8 NTU.

Figure 21. Images of the Single-Shell Tank Simulant Retest Filter Cake for the Three Different Li-Loadings after Four Hours.

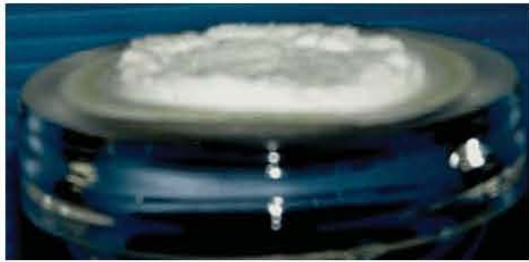

$0.2 \mathrm{MLi}$

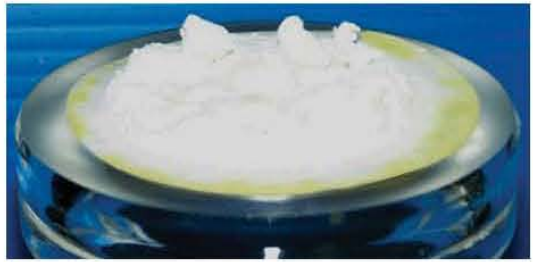

$0.3 \mathrm{MLi}$

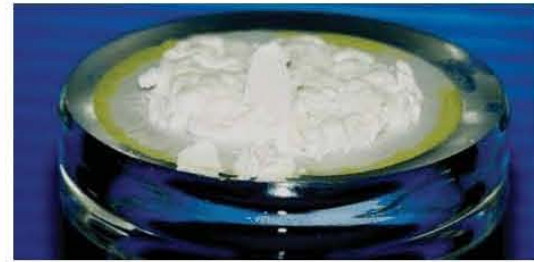

$0.4 \mathrm{M} \mathrm{Li}$

In Figures 22 and 23 the SEM results for the filter cakes after 30 minutes and after 4 hours are compared. Figure 22 shows the 30 -minute filter cake samples analyzed with the SEM. The needle-shaped phase in the BSE image on the right of Figure 22 is most likely a piece of the glass fiber filter - hence the huge $\mathrm{Si}, \mathrm{Ca}$, and $\mathrm{Al}$ peaks. The precipitated particles have the same composition as in case of $0.3-\mathrm{M} \mathrm{Li}$.

\footnotetext{
${ }^{11} 0.2 \mathrm{M}$ Li SST retest: $0.24 \mathrm{~g}$ (wet weight) $*(1000 / 300)=0.19 \mathrm{~g}$ (recalculated to $\left.1-\mathrm{L}\right) \Rightarrow 5 \mathrm{wt} \%$ of SST original $(7.84 \mathrm{~g})$.
} 
Figure 22. Back Scattered Electron Images and Energy Dispersive Spectrometry Spectra of Single-Shell Tank Simulant Retest Filter Cake after 30 Minutes.

$0.2 \mathrm{M} \mathrm{Li}$
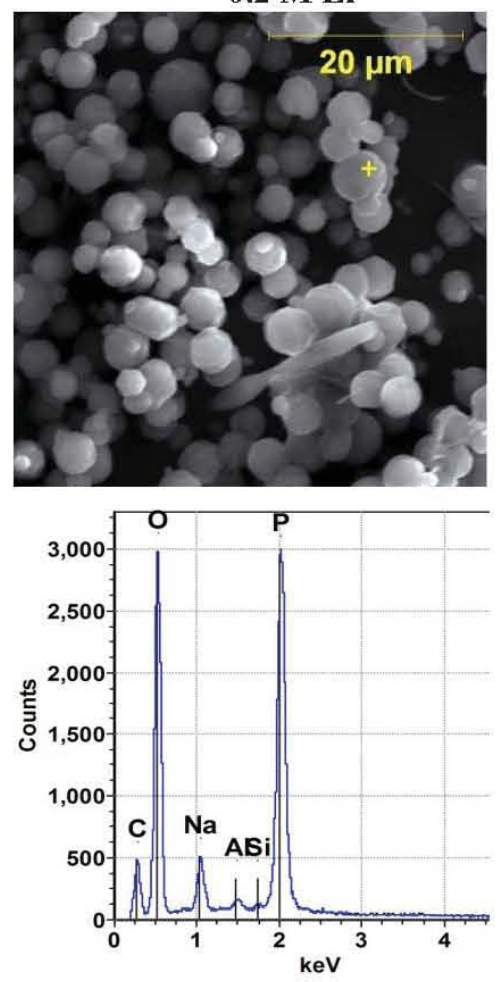

$0.3 \mathrm{M} \mathrm{Li}$
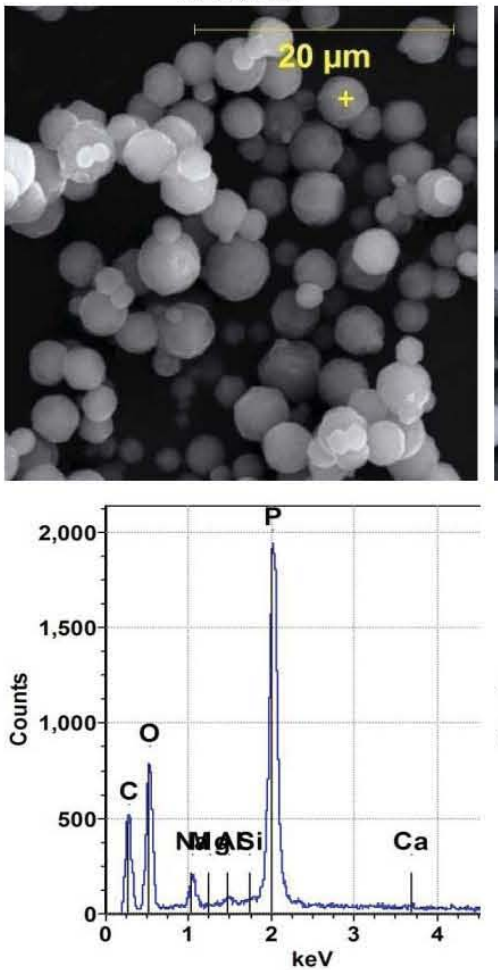

$0.4 \mathrm{M} \mathrm{Li}$
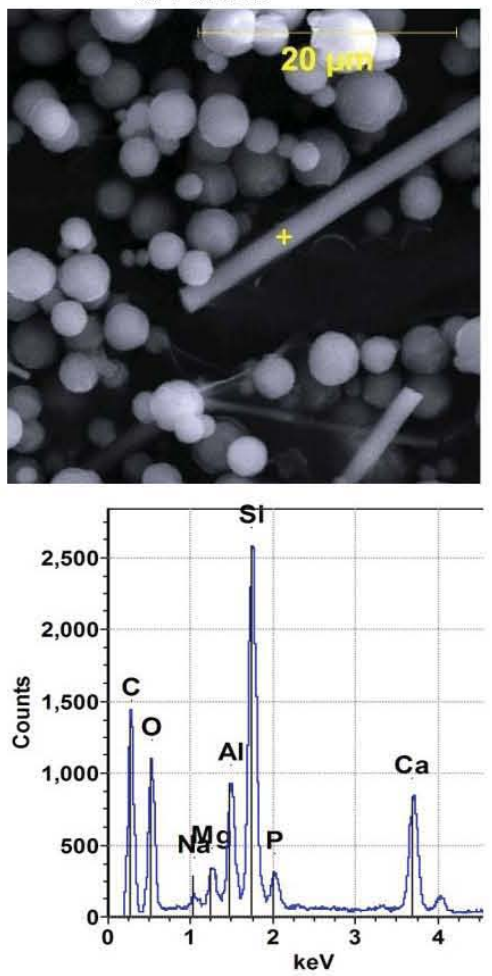

In Figure 23, the analytical results of samples of the filter cakes from the three different Liloadings after 4 hours are shown. No substantial changes between the products were identifiable by SEM and EDS. Some of the spheres show a loss of the central portion. This could be due to leaching in the water wash steps or to loss during the 4 hours of ripening. Despite the reduced integrity of the spheres, the filter cake samples after 4 hours have a more complex look to them (more overgrowth) than the 30 -minute samples.

Figure 24 shows the XRD spectrum for the 0.4-M Li ( $\mathrm{Li}: \mathrm{Al}=1)$ - for comparison, check the 0.2-M Li product XRD spectrum in Figure 19. The 0.4-M Li XRD spectrum shows Liphosphate still as the major component, with minor amounts of cancrinite.

However, a trace of the Li-hydrotalcite could be identified. Even at the small angle of $11.5^{\circ} 2-\theta$ \{representing the (100) plane\}, a clear peak is visible. This shows that adding twice the assumed Li-demand may be the threshold of the concentration needed to start the precipitation of Lihydrotalcite for the SST simulant. 
Figure 23. Back Scattered Electron Images and Energy Dispersive Spectrometry Spectra of Single-Shell Tank Simulant Retest Filter Cake after Four Hours.
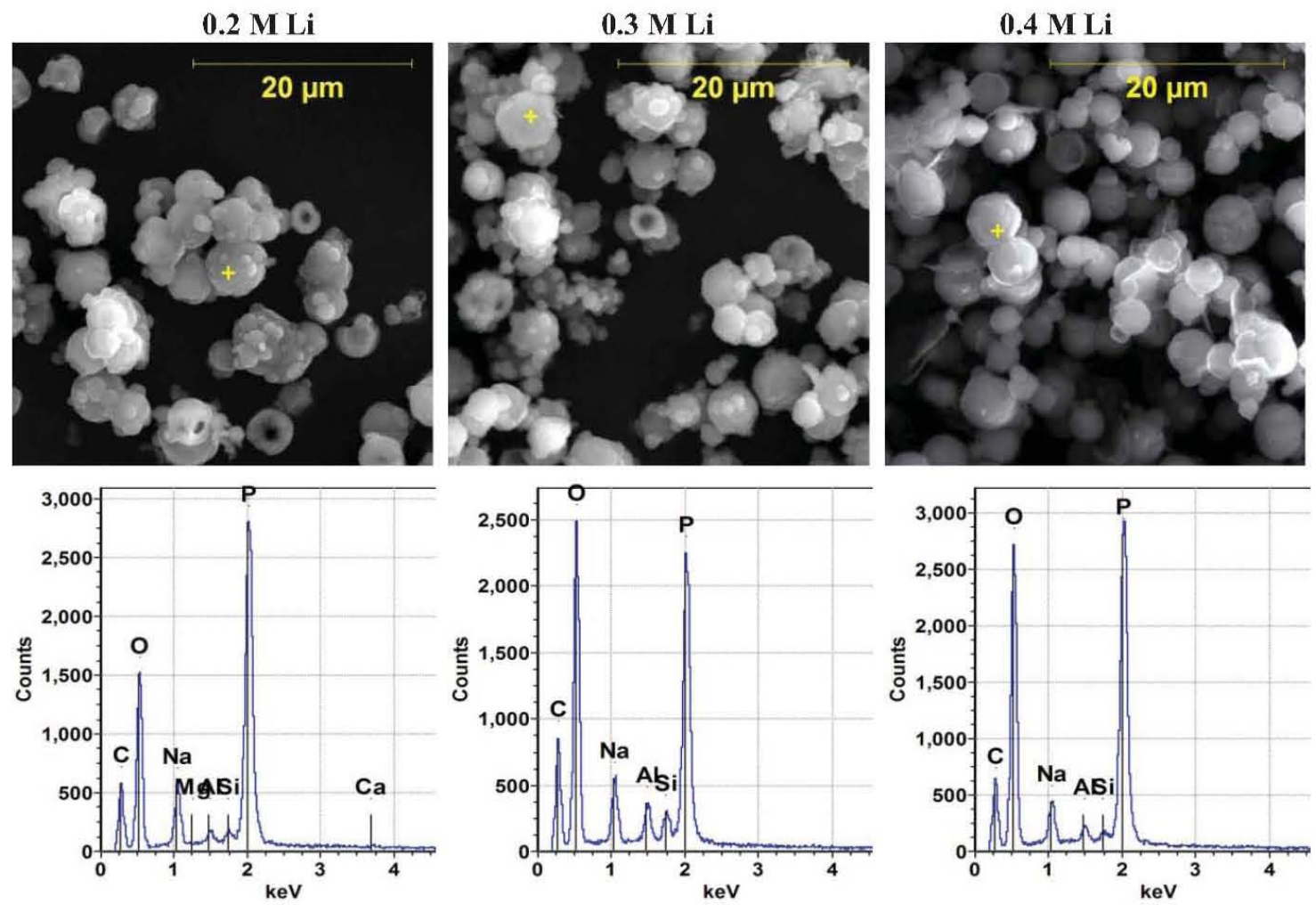

Figure 24. X-Ray Diffraction Spectrum of 0.4 M-Li Single-Shell Tank Simulant Retest Filter Cake after Four Hours.

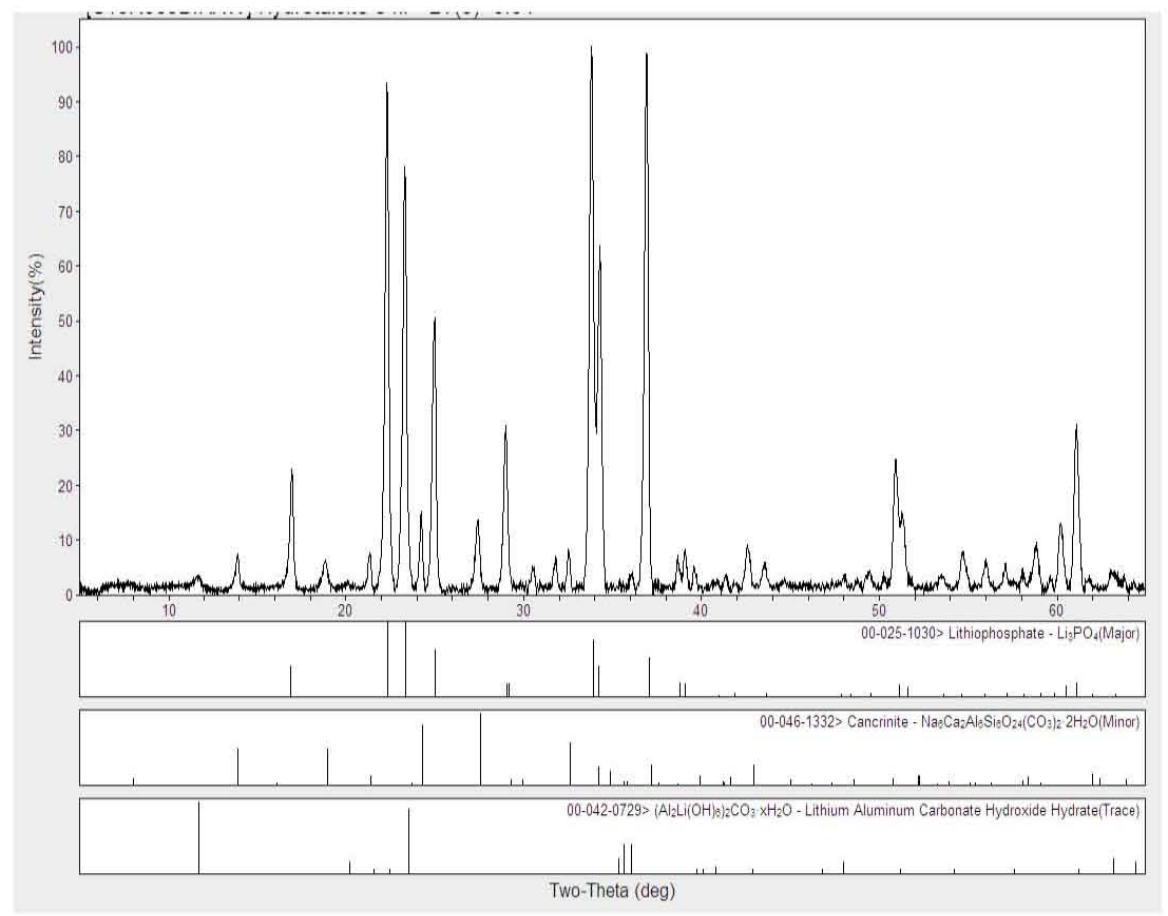




\subsection{SUMMARY AND RECOMMENDATIONS}

A summary of the test results is presented in Table 8. For the DST simulant, the amount of aluminum and lithium retained in the filter cake is in the $90+$ mol $\%$ range. This product is composed primarily of lithium-aluminum-carbonate-hydroxide hydrate (i.e., Li-hydrotalcite). The Li-hydrotalcite that formed contains primarily carbonate (TIC) as the intercalated anion. It is unlikely that the nitrate and nitrite retained in the filter cake could be intercalated; however, the XRD results indicated sodium nitrate, $\mathrm{NaNO}_{3}$, as the minor phase.

Table 8. Amounts of Assorted Analytes Retained in the Washed Filter Cakes.

\begin{tabular}{|c|c|c|c|c|}
\hline \multirow{2}{*}{ Analyte } & \multicolumn{2}{|c|}{ DST Filtercake } & \multicolumn{2}{|c|}{ SST Filtercake (Initial Test) } \\
\hline & {$[\mathrm{mol}]$} & {$[\mathrm{mol} \%]$} & [mol] & {$[\mathrm{mol} \%]$} \\
\hline Aluminum & 0.84 & 92 & 0.030 & 7.9 \\
\hline Lithium & 0.508 & 93 & 0.165 & 77.3 \\
\hline $\mathrm{TIC}$ & 1.8 & 99.9 & 0.002 & 1.8 \\
\hline Phosphorus & 0.0069 & 95.5 & 0.038 & 78.3 \\
\hline Nitrate & 0.148 & 14 & n.r. & n.r. \\
\hline Nitrite & 0.165 & 15 & n.r. & n.r. \\
\hline Hydroxide & 0.122 & 3.86 & n.r. & n.r. \\
\hline Fluoride & 0.003 & 32.5 & n.r. & n.r. \\
\hline Sulfur & n.r. & n.r. & n.r. & n.r. \\
\hline Cs-133 & 0.0001 & 16.7 & n.r. & n.r. \\
\hline
\end{tabular}

Amount retained is calculated as the difference between the filtrate after gibbsite leaching (supernate) and the sum of the post-Li-addition filtrate plus all of the water washes (for analytical results see Appendix B). n.r. not retained.

Based on the values shown in Table 8, the following calculations can be made for the DST test: the filter cake contained $\sim 0.23 \mathrm{~mol}$ carbonate Li-hydrotalcite ${ }^{12}\left(\left[\mathrm{LiAl}_{2}(\mathrm{OH})_{6}\right]_{2} \mathrm{CO}_{3} \cdot 3 \mathrm{H}_{2} \mathrm{O}\right)$ with a molecular weight of $439.9 \mathrm{~g} / \mathrm{mol}$. This would refer to $102 \mathrm{~g}$ of Li-hydrotalcite in the filter cake. The calculated amount of sodium nitrate based on Table 6 would be $13 \mathrm{~g}$. The wet filter cake weighed $130.6 \mathrm{~g}$; thus, the wet filter cake only contained $16 \mathrm{~g}(12 \mathrm{wt} \%)$ moisture. The dry weight based on this result is $114.6 \mathrm{~g}$. The question of which phase contained the rest of the carbonate $(1.8 \mathrm{~mol} \mathrm{TIC}-0.23 \mathrm{~mol}$ in $\mathrm{LiHT}=1.6 \mathrm{~mol})$ remains unanswered.

In the case of the SST simulant, very little aluminum is retained $(\sim 8 \mathrm{~mol} \%)$, but $\sim 75 \mathrm{~mol} \%$ of the lithium and phosphorus precipitated as lithium phosphate. The reason why $25 \mathrm{~mol} \%$ of the lithium did not precipitate could not be identified. The aluminum in the SST supernate generally did not react at all. Some formed cancrinite (NaAl-silicate) with silicon leached from the glass beaker.

The SST retest with variable amounts of lithium $(\mathrm{Li}: \mathrm{Al}=0.5-1)$ showed that a certain lithium concentration does produce Li-hydrotalcite beside the omnipresent Li-phosphate. However,

\footnotetext{
${ }^{12}$ Each mol LiHT is made of $4 \mathrm{~mol} \mathrm{Al}$ and $2 \mathrm{~mol} \mathrm{Li}=>1 / 4$ of the mole $\mathrm{Al}(0.84 / 4=0.21)$ and $1 / 2$ of the mole $\mathrm{Li}$ $(0.508 / 2=0.254)$, on average $0.23 \mathrm{~mol} \mathrm{LiHT}$.
} 
even in the case of $\mathrm{Li}: \mathrm{Al}=1$, only trace amounts of $\mathrm{Li}$-hydrotalcite were observed. In order to remove the misleading contribution of Si from the glass beakers, the SST test should be rerun using Teflon ${ }^{13}$ reaction vessels and increasing $\mathrm{Li}$ :Al ratios to determine when the maximum production of hydrotalcite occurs.

Besides the formation of Li-phosphate, no other competing reactions were evident within this effort. Theoretically, the formation of Li-fluoride and $\mathrm{Li}$-carbonate are potential reactions to interfere with the precipitation of the Li-hydrotalcite. As shown in Table 9, the solubility of the individual lithium salts is highly variable $\left(\mathrm{CRC}^{14}\right.$ Handbook of Chemistry and Physics, 90th Edition). One of the unknowns to date is the solubility of the LiHT within the conditions of the SST stimulant.

\section{Table 9. Solubility Products and Solubilities for Different Lithium Compounds.}

\begin{tabular}{|c|c|c|}
\hline Compound & $\mathrm{K}_{\mathrm{sp}}\left(\text { at } 25^{\circ} \mathrm{C}\right)^{\mathrm{a}}$ & $\begin{array}{l}\text { Solubility in } \\
\text { Water }^{\mathrm{b}}(\mathrm{g} / \mathrm{L})\end{array}$ \\
\hline $\mathrm{LiNO}_{3}$ & Not Reported & $1020\left(25^{\circ} \mathrm{C}\right)$ \\
\hline $\mathrm{Li}_{2} \mathrm{SO}_{4}$ & Not Reported & $342\left(25^{\circ} \mathrm{C}\right)$ \\
\hline$\overline{\mathrm{Li}_{2} \mathrm{CO}_{3}}$ & $8.15 \mathrm{E}-04$ & $13.0\left(25^{\circ} \mathrm{C}\right)$ \\
\hline $\mathrm{LiF}$ & $1.84 \mathrm{E}-03$ & $1.34\left(25^{\circ} \mathrm{C}\right)$ \\
\hline $\mathrm{Li}_{3} \mathrm{PO}_{4}$ & $2.37 \mathrm{E}-11$ & $0.27\left(25^{\circ} \mathrm{C}\right)$ \\
\hline $\mathrm{LiOH}$ & Not Reported & $125(25 \mathrm{C})$ \\
\hline
\end{tabular}

From the observations during the SST retest, the following can be derived: The first precipitate was $\mathrm{Li}$-phosphate. Even in the slightly elevated $\mathrm{Li}: \mathrm{Al}=3: 4$ case $(0.3-\mathrm{M} \mathrm{Li})$, no clear sign of $\mathrm{Li}-$ hydrotalcite was observed. In the case of the $\mathrm{Li}: \mathrm{Al}=1$, the carbonate Li-hydrotalcite could be identified with XRD; thus, at least $5 \%$ of the crystals were Li-hydrotalcite. This implies that the solubility of the Li-hydrotalcite is higher than $\mathrm{Li}$-phosphate, but lower than $\mathrm{Li}$-carbonate and Lifluoride. Although the amount of fluoride in the simulant is insufficient to be detected by XRD even if all of it precipitated as Li-fluoride, Table 8 shows that none of the fluoride was retained in the filter cake.

In summary the authors make the following recommendations (not to be construed as an allinclusive list):

\footnotetext{
${ }^{13}$ Teflon is a trademark of the E. I. DuPont De Nemours and Company, Wilmington, Delaware.

${ }^{14} \mathrm{CRC}$ is a registered trademark of the CR Press, Inc., Corporation, Boca Raton, Florida
} 
- Optimize reaction and crystal ripening time. Identify the particle-size phases.

- Optimize the heating and cooling cycles of the filtrate.

- Monitor anions to identify the limiting factors for precipitation. Determine whether or not an increase in release of certain anions and cations during the later stages of washes are real or an analytical artifact.

- Investigate the effect of filter cake washes (chemistries, $\mathrm{pH}$, types, and number) on the product. Place special focus on up-flow bed expansion versus down-flow.

- Select reactors with appropriate materials of construction (Teflon, stainless steel) for the SST tests.

- Determine the threshold lithium concentrations for various waste types based upon the lithium demand in the waste. Identify the boundaries of the effects of different ionic strength solutions.

- Obtain XRD and Raman spectra of each potential species of LiHT under the WTP conditions with the anions present in most of the tanks at Hanford site. 


\subsection{REFERENCES}

ORP-11242, 2009, River Protection Project System Plan, Rev. 4, Washington River Protection Solutions, LLC, Richland, WA.

CH2M-0403873, 2004, Preparation of Simulated Waste Samples for EM-21 Project, CH2M HILL Hanford Group, Richland, WA.

LAB-PLAN-09-00003, 2009, Validation of Initial Laboratory Experiments Using Lithium Aluminum Layered Double Hydroxides for the Reduction of Alumina from the Waste Treatment Plant Feedstock, Washington River Protection Solutions, LLC, Richland, WA.

CRC Press, 2000, Handbook of Chemistry and Physics, D. R. Lide, Editor in Chief, New York, $90^{\text {th }}$ Edition.

E.F. Allen and H.F. Rodgers, 1900, The Action of Caustic Hydroxides on Aluminum, American Chemical Journal 24, pp. 304-318. 
LAB-RPT-10-00003

Revision 0

\section{APPENDIX A}

Sample Breakdown Diagrams 
LAB-RPT-10-00003

Revision 0

\section{Sample Breakdown Diagrams}

Customer: RESEARCH

Project: Hydrotalcite Test

Group: 20090884

Due: January 15, 2010

\section{Hydrotalcite Test - DST}

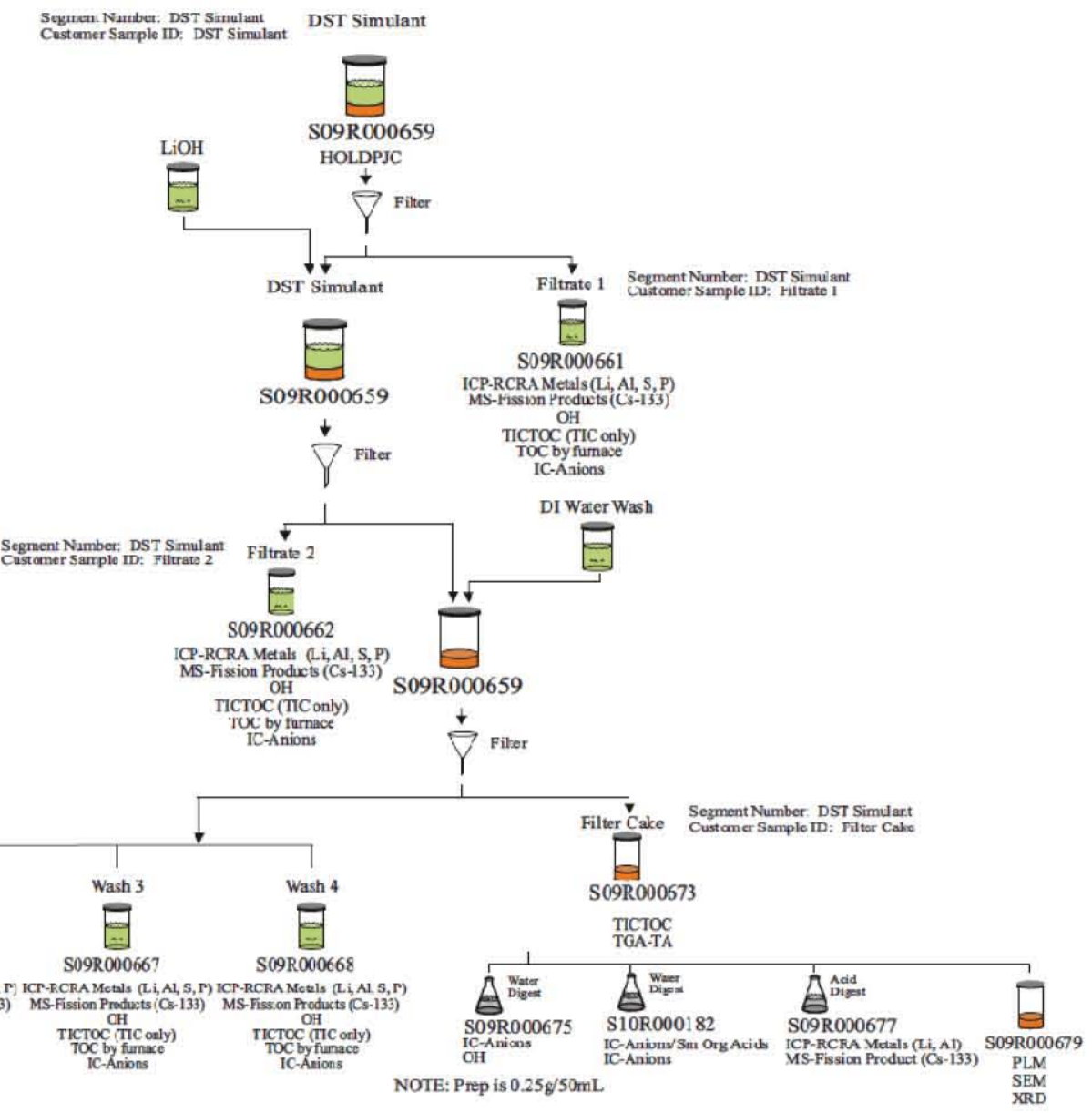


LAB-RPT-10-00003

Revision 0

Customer: RESEARCH

Project: Hydrotalcite Test

Group: 20090884

Due: January 15,2010

\section{Hydrotalcite Test - SST}

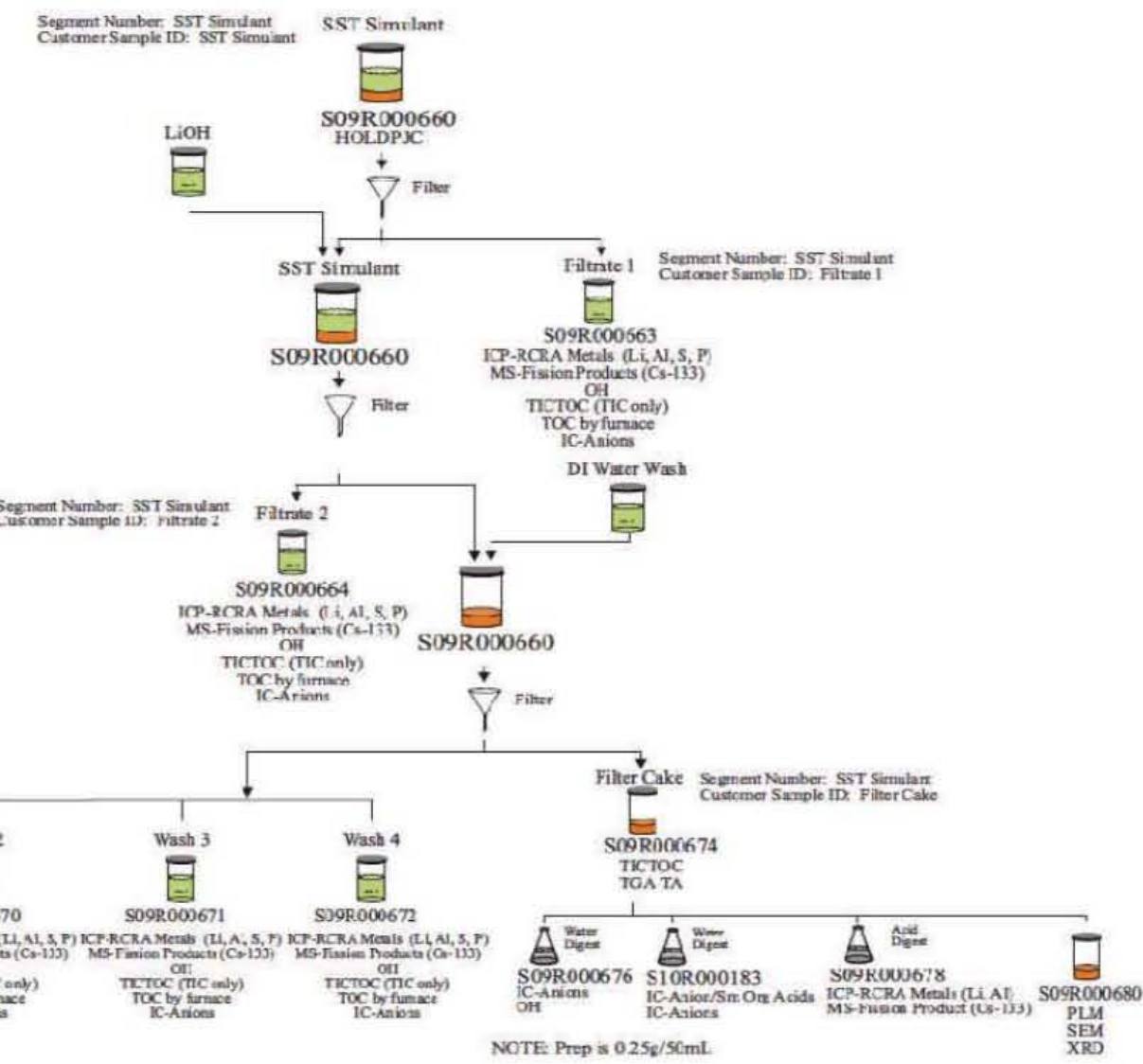

Customer: RESEARCH

Project: Hydrotalcite Test

Group: 20090884

Due: January 15, 2010

\section{Hydrotalcite Test - SST, Run 2}

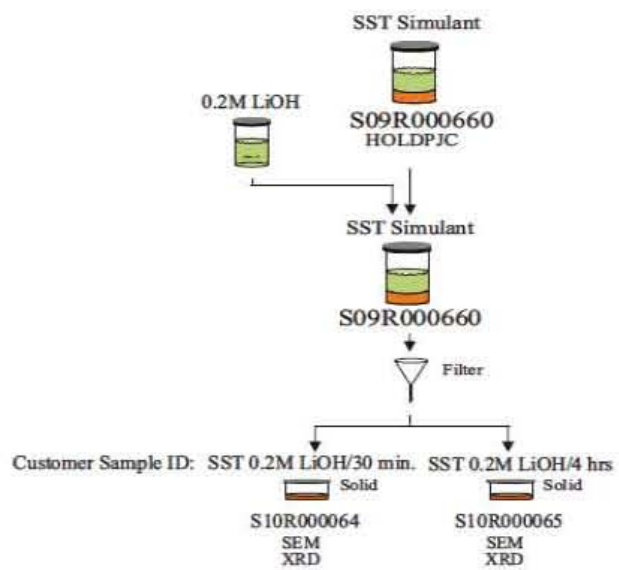

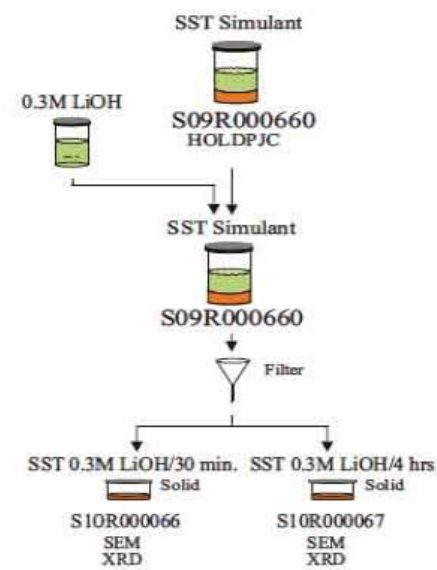

SEM

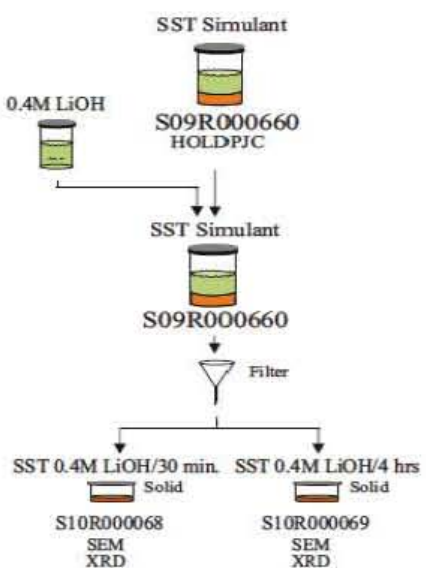




\section{APPENDIX B}

Data Summary of Chemical Analyses as Provided by Advanced Technologies and Laboratories International, Inc. (ATL) 


\section{Data Summary of Chemical Analyses as Provided by Advanced Technologies and Laboratories International, Inc. (ATL)}

Note: "Filtrate 1" is referred to as "Supernate" in the text; "Filtrate 2" as "Filtrate."

10-feb-2010 11:51:03

Hydrotalcite Test

Data Summary of All Results

\begin{tabular}{|c|c|c|c|c|c|c|c|c|c|}
\hline ID & & SAMPLE & ANALYTE & UNIT & RESULT & DUP. & AVE. & RPD & QA \\
\hline DST Simulant & Filter Cake & S09R000673 & Percent water & $\%$ & 67.8 & 64.6 & 66.2 & 4.77 & \\
\hline DST Simulant & Filter Cake & S09R000673 & Total organic carbon & $\mathrm{ug} / \mathrm{g}$ & $<169$ & 207 & $\mathrm{n} / \mathrm{a}$ & $\mathrm{n} / \mathrm{a}$ & $\mathrm{U}$ \\
\hline DST Simulant & Filter Cake & S09R000673 & Total inorganic carbon & $\mathrm{ug} / \mathrm{g}$ & $5.81 \mathrm{E}+03$ & $5.98 \mathrm{E}+03$ & $5.90 \mathrm{E}+03$ & 2.88 & \\
\hline DST Simulant & Filter Cake & S09R000675 & Hydroxide & $\mathrm{ug} / \mathrm{g}$ & $<1.66 \mathrm{E}+03$ & $\mathrm{n} / \mathrm{a}$ & $\mathrm{n} / \mathrm{a}$ & $\mathrm{n} / \mathrm{a}$ & $\mathrm{U}$ \\
\hline DST Simulant & Filter Cake & S09R000677 & Aluminum & $\mathrm{ug} / \mathrm{g}$ & $8.57 \mathrm{E}+04$ & $8.72 \mathrm{E}+04$ & $8.64 \mathrm{E}+04$ & 1.74 & \\
\hline DST Simulant & Filter Cake & S09R000677 & Lithium & $\mathrm{ug} / \mathrm{g}$ & $1.11 \mathrm{E}+04$ & $1.19 \mathrm{E}+04$ & $1.15 \mathrm{E}+04$ & 7.29 & \\
\hline DST Simulant & Filter Cake & S09R000677 & Phosphorus & $\mathrm{ug} / \mathrm{g}$ & $1.56 \mathrm{E}+03$ & $1.55 \mathrm{E}+03$ & $1.56 \mathrm{E}+03$ & 0.921 & \\
\hline DST Simulant & Filter Cake & S09R000677 & Sulfur & $\mathrm{ug} / \mathrm{g}$ & $<77.0$ & $<76.8$ & $\mathrm{n} / \mathrm{a}$ & $\mathrm{n} / \mathrm{a}$ & $\mathrm{U}$ \\
\hline DST Simulant & Filter Cake & S09R000677 & Silicon & $\mathrm{ug} / \mathrm{g}$ & 233 & 229 & 231 & 1.36 & \\
\hline DST Simulant & Filter Cake & S09R000677 & Cesium-133 & $\mathrm{ug} / \mathrm{g}$ & 2.70 & 2.73 & 2.72 & 0.89 & \\
\hline DST Simulant & Filtrate 1 & S09R000661 & Fluoride & $\mathrm{ug} / \mathrm{mL}$ & 191 & $\mathrm{n} / \mathrm{a}$ & $\mathrm{n} / \mathrm{a}$ & $\mathrm{n} / \mathrm{a}$ & \\
\hline DST Simulant & Filtrate 1 & S09R000661 & Chloride & $\mathrm{ug} / \mathrm{mL}$ & $4.43 \mathrm{E}+03$ & $\mathrm{n} / \mathrm{a}$ & $\mathrm{n} / \mathrm{a}$ & $n / a$ & \\
\hline DST Simulant & Filtrate 1 & S09R000661 & Nitrite & $\mathrm{ug} / \mathrm{mL}$ & $5.65 \mathrm{E}+04$ & $\mathrm{n} / \mathrm{a}$ & $n / a$ & $n / a$ & \\
\hline DST Simulant & Filtrate 1 & S09R000661 & Bromide & $\mathrm{ug} / \mathrm{mL}$ & $<26.3$ & $\mathrm{n} / \mathrm{a}$ & $\mathrm{n} / \mathrm{a}$ & $n / a$ & $\mathrm{U}$ \\
\hline DST Simulant & Filtrate 1 & S09R000661 & Nitrate & $\mathrm{ug} / \mathrm{mL}$ & $7.29 \mathrm{E}+04$ & $\mathrm{n} / \mathrm{a}$ & $\mathrm{n} / \mathrm{a}$ & $n / a$ & \\
\hline DST Simulant & Filtrate 1 & S09R000661 & Phosphate & $\mathrm{ug} / \mathrm{mL}$ & $1.48 \mathrm{E}+03$ & $\mathrm{n} / \mathrm{a}$ & $\mathrm{n} / \mathrm{a}$ & $n / a$ & \\
\hline DST Simulant & Filtrate 1 & S09R000661 & Sulfate & $\mathrm{ug} / \mathrm{mL}$ & $1.01 \mathrm{E}+03$ & $\mathrm{n} / \mathrm{a}$ & $\mathrm{n} / \mathrm{a}$ & $n / a$ & \\
\hline DST Simulant & Filtrate 1 & S09R000661 & Oxalate & $\mathrm{ug} / \mathrm{mL}$ & $<117$ & $\mathrm{n} / \mathrm{a}$ & $\mathrm{n} / \mathrm{a}$ & $\mathrm{n} / \mathrm{a}$ & $\mathrm{U}$ \\
\hline DST Simulant & Filtrate 1 & S09R000661 & Aluminum & $\mathrm{ug} / \mathrm{mL}$ & $2.80 \mathrm{E}+04$ & $\mathrm{n} / \mathrm{a}$ & $\mathrm{n} / \mathrm{a}$ & $n / a$ & \\
\hline DST Simulant & Filtrate 1 & S09R000661 & Lithium & $\mathrm{ug} / \mathrm{mL}$ & $<0.600$ & $\mathrm{n} / \mathrm{a}$ & $\mathrm{n} / \mathrm{a}$ & $\mathrm{n} / \mathrm{a}$ & $\mathrm{U}$ \\
\hline DST Simulant & Filtrate 1 & S09R000661 & Phosphorus & $\mathrm{ug} / \mathrm{mL}$ & 253 & $\mathrm{n} / \mathrm{a}$ & $\mathrm{n} / \mathrm{a}$ & $\mathrm{n} / \mathrm{a}$ & \\
\hline DST Simulant & Filtrate 1 & S09R000661 & Sulfur & $\mathrm{ug} / \mathrm{mL}$ & 207 & $\mathrm{n} / \mathrm{a}$ & $\mathrm{n} / \mathrm{a}$ & n/a & \\
\hline DST Simulant & Filtrate 1 & S09R000661 & Silicon & $\mathrm{ug} / \mathrm{mL}$ & 54.6 & $\mathrm{n} / \mathrm{a}$ & $\mathrm{n} / \mathrm{a}$ & $\mathrm{n} / \mathrm{a}$ & $\mathrm{J}$ \\
\hline DST Simulant & Filtrate 1 & S09R000661 & Cesium-133 & $\mathrm{ug} / \mathrm{mL}$ & 84.0 & 84.6 & 84.3 & 0.71 & \\
\hline DST Simulant & Filtrate 1 & S09R000661 & Hydroxide & $\mathrm{ug} / \mathrm{mL}$ & $3.25 \mathrm{E}+04$ & $3.27 \mathrm{E}+04$ & $3.26 \mathrm{E}+04$ & 0.72 & \\
\hline DST Simulant & Filtrate 1 & S09R000661 & Total inorganic carbon & $\mathrm{ug} / \mathrm{mL}$ & $1.22 \mathrm{E}+05$ & $\mathrm{n} / \mathrm{a}$ & $\mathrm{n} / \mathrm{a}$ & $n / a$ & \\
\hline DST Simulant & Filtrate 1 & S09R000661 & Total organic carbon & $\mathrm{ug} / \mathrm{mL}$ & $1.42 \mathrm{E}+03$ & $\mathrm{n} / \mathrm{a}$ & $\mathrm{n} / \mathrm{a}$ & $n / a$ & c \\
\hline DST Simulant & Filtrate 2 & S09R000662 & Fluoride & $\mathrm{ug} / \mathrm{mL}$ & 167 & 166 & 166 & 0.19 & \\
\hline DST Simulant & Filtrate 2 & S09R000662 & Chloride & $\mathrm{ug} / \mathrm{mL}$ & $4.53 \mathrm{E}+03$ & $4.51 \mathrm{E}+03$ & $4.52 \mathrm{E}+03$ & 0.44 & \\
\hline DST Simulant & Filtrate 2 & S09R000662 & Nitrite & $\mathrm{ug} / \mathrm{mL}$ & $5.97 \mathrm{E}+04$ & $6.00 \mathrm{E}+04$ & $5.99 \mathrm{E}+04$ & 0.64 & \\
\hline DST Simulant & Filtrate 2 & S09R000662 & Bromide & $\mathrm{ug} / \mathrm{mL}$ & $<26.3$ & $<26.3$ & $\mathrm{n} / \mathrm{a}$ & $\mathrm{n} / \mathrm{a}$ & $\mathrm{U}$ \\
\hline DST Simulant & Filtrate 2 & S09R000662 & Nitrate & $\mathrm{ug} / \mathrm{mL}$ & $7.82 \mathrm{E}+04$ & $7.79 \mathrm{E}+04$ & $7.81 \mathrm{E}+04$ & 0.45 & \\
\hline DST Simulant & Filtrate 2 & S09R000662 & Phosphate & $\mathrm{ug} / \mathrm{mL}$ & $<42.3$ & $<42.3$ & $\mathrm{n} / \mathrm{a}$ & $\mathrm{n} / \mathrm{a}$ & $\mathrm{U}$ \\
\hline DST Simulant & Filtrate 2 & S09R000662 & Sulfate & $\mathrm{ug} / \mathrm{mL}$ & 768 & 787 & 777 & 2.45 & \\
\hline DST Simulant & Filtrate 2 & S09R000662 & Oxalate & $\mathrm{ug} / \mathrm{mL}$ & $<117$ & $<117$ & $\mathrm{n} / \mathrm{a}$ & $\mathrm{n} / \mathrm{a}$ & $\mathrm{U}$ \\
\hline DST Simulant & Filtrate 2 & S09R000662 & Aluminum & $\mathrm{ug} / \mathrm{mL}$ & $2.17 \mathrm{E}+03$ & $\mathrm{n} / \mathrm{a}$ & $\mathrm{n} / \mathrm{a}$ & $n / a$ & \\
\hline DST Simulant & Filtrate 2 & S09R000662 & Lithium & $\mathrm{ug} / \mathrm{mL}$ & 238 & $\mathrm{n} / \mathrm{a}$ & $\mathrm{n} / \mathrm{a}$ & $n / a$ & \\
\hline DST Simulant & Filtrate 2 & S09R000662 & Phosphorus & $\mathrm{ug} / \mathrm{mL}$ & 12.3 & $\mathrm{n} / \mathrm{a}$ & $\mathrm{n} / \mathrm{a}$ & $n / a$ & $\mathrm{~J}$ \\
\hline DST Simulant & Filtrate 2 & S09R000662 & Sulfur & $\mathrm{ug} / \mathrm{mL}$ & 281 & $\mathrm{n} / \mathrm{a}$ & $\mathrm{n} / \mathrm{a}$ & $\mathrm{n} / \mathrm{a}$ & \\
\hline DST Simulant & Filtrate 2 & S09R000662 & Silicon & $\mathrm{ug} / \mathrm{mL}$ & 72.3 & $\mathrm{n} / \mathrm{a}$ & $\mathrm{n} / \mathrm{a}$ & $\mathrm{n} / \mathrm{a}$ & \\
\hline
\end{tabular}


LAB-RPT-10-00003

Revision 0

\begin{tabular}{|c|c|c|c|c|c|c|c|c|c|}
\hline ID & & SAMPLE & ANALYTE & UNIT & RESULT & DUP. & AVE. & RPD & QA \\
\hline DST Simulant & Filtrate 2 & S09R000662 & Cesium-133 & $\mathrm{ug} / \mathrm{mL}$ & 87.6 & $\mathrm{n} / \mathrm{a}$ & $\mathrm{n} / \mathrm{a}$ & $\mathrm{n} / \mathrm{a}$ & \\
\hline DST Simulant & Filtrate 2 & S09R000662 & Hydroxide & $\mathrm{ug} / \mathrm{mL}$ & $5.05 \mathrm{E}+04$ & $\mathrm{n} / \mathrm{a}$ & $\mathrm{n} / \mathrm{a}$ & $\mathrm{n} / \mathrm{a}$ & \\
\hline DST Simulant & Filtrate 2 & S09R000662 & Total inorganic carbon & $\mathrm{ug} / \mathrm{mL}$ & 138 & $n / a$ & $\mathrm{n} / \mathrm{a}$ & $\mathrm{n} / \mathrm{a}$ & \\
\hline DST Simulant & Filtrate 2 & S09R000662 & Total organic carbon & $\mathrm{ug} / \mathrm{mL}$ & $1.34 \mathrm{E}+03$ & $\mathrm{n} / \mathrm{a}$ & $\mathrm{n} / \mathrm{a}$ & $\mathrm{n} / \mathrm{a}$ & $\mathrm{c}$ \\
\hline DST Simulant & Wash 1 & S09R000665 & Fluoride & $\mathrm{ug} / \mathrm{mL}$ & 4.37 & $\mathrm{n} / \mathrm{a}$ & $\mathrm{n} / \mathrm{a}$ & $\mathrm{n} / \mathrm{a}$ & \\
\hline DST Simulant & Wash 1 & S09R000665 & Chloride & $\mathrm{ug} / \mathrm{mL}$ & 245 & $\mathrm{n} / \mathrm{a}$ & $\mathrm{n} / \mathrm{a}$ & $\mathrm{n} / \mathrm{a}$ & \\
\hline DST Simulant & Wash 1 & S09R000665 & Nitrite & $\mathrm{ug} / \mathrm{mL}$ & $3.26 \mathrm{E}+03$ & $n / a$ & $n / a$ & $\mathrm{n} / \mathrm{a}$ & \\
\hline DST Simulant & Wash 1 & S09R000665 & Bromide & $\mathrm{ug} / \mathrm{mL}$ & $<0.261$ & $\mathrm{n} / \mathrm{a}$ & $\mathrm{n} / \mathrm{a}$ & $\mathrm{n} / \mathrm{a}$ & $\mathrm{U}$ \\
\hline DST Simulant & Wash 1 & S09R000665 & Nitrate & $\mathrm{ug} / \mathrm{mL}$ & $4.09 \mathrm{E}+03$ & $\mathrm{n} / \mathrm{a}$ & $\mathrm{n} / \mathrm{a}$ & $\mathrm{n} / \mathrm{a}$ & \\
\hline DST Simulant & Wash 1 & S09R000665 & Phosphate & $\mathrm{ug} / \mathrm{mL}$ & $<0.419$ & $\mathrm{n} / \mathrm{a}$ & $\mathrm{n} / \mathrm{a}$ & $\mathrm{n} / \mathrm{a}$ & $\mathrm{U}$ \\
\hline DST Simulant & Wash 1 & S09R000665 & Sulfate & $\mathrm{ug} / \mathrm{mL}$ & 31.7 & $\mathrm{n} / \mathrm{a}$ & $\mathrm{n} / \mathrm{a}$ & $\mathrm{n} / \mathrm{a}$ & \\
\hline DST Simulant & Wash 1 & S09R000665 & Oxalate & $\mathrm{ug} / \mathrm{mL}$ & $<1.16$ & $\mathrm{n} / \mathrm{a}$ & $\mathrm{n} / \mathrm{a}$ & $\mathrm{n} / \mathrm{a}$ & $\mathrm{U}$ \\
\hline DST Simulant & Wash 1 & S09R000665 & Aluminum & $\mathrm{ug} / \mathrm{mL}$ & 509 & $\mathrm{n} / \mathrm{a}$ & $\mathrm{n} / \mathrm{a}$ & $n / a$ & \\
\hline DST Simulant & Wash 1 & S09R000665 & Lithium & $\mathrm{ug} / \mathrm{mL}$ & 77.8 & $\mathrm{n} / \mathrm{a}$ & $\mathrm{n} / \mathrm{a}$ & $\mathrm{n} / \mathrm{a}$ & \\
\hline DST Simulant & Wash 1 & S09R000665 & Phosphorus & $\mathrm{ug} / \mathrm{mL}$ & $<1.00$ & $\mathrm{n} / \mathrm{a}$ & $\mathrm{n} / \mathrm{a}$ & $\mathrm{n} / \mathrm{a}$ & $\mathrm{U}$ \\
\hline DST Simulant & Wash 1 & S09R000665 & Sulfur & $\mathrm{ug} / \mathrm{mL}$ & 10.8 & $\mathrm{n} / \mathrm{a}$ & $\mathrm{n} / \mathrm{a}$ & $\mathrm{n} / \mathrm{a}$ & $\mathrm{J}$ \\
\hline DST Simulant & Wash 1 & S09R000665 & Silicon & $\mathrm{ug} / \mathrm{mL}$ & 3.06 & $\mathrm{n} / \mathrm{a}$ & $\mathrm{n} / \mathrm{a}$ & $\mathrm{n} / \mathrm{a}$ & $\mathrm{J}$ \\
\hline DST Simulant & Wash 1 & S09R000665 & Cesium-133 & $\mathrm{ug} / \mathrm{mL}$ & 4.75 & $\mathrm{n} / \mathrm{a}$ & $\mathrm{n} / \mathrm{a}$ & $\mathrm{n} / \mathrm{a}$ & \\
\hline DST Simulant & Wash 1 & S09R000665 & Hydroxide & $\mathrm{ug} / \mathrm{mL}$ & $2.89 \mathrm{E}+03$ & $\mathrm{n} / \mathrm{a}$ & $\mathrm{n} / \mathrm{a}$ & $\mathrm{n} / \mathrm{a}$ & \\
\hline DST Simulant & Wash 1 & S09R000665 & Total inorganic carbon & $\mathrm{ug} / \mathrm{mL}$ & 33.6 & $\mathrm{n} / \mathrm{a}$ & $\mathrm{n} / \mathrm{a}$ & $n / a$ & $\mathrm{~J}$ \\
\hline DST Simulant & Wash 1 & S09R000665 & Total organic carbon & $\mathrm{ug} / \mathrm{mL}$ & 143 & $\mathrm{n} / \mathrm{a}$ & $\mathrm{n} / \mathrm{a}$ & $\mathrm{n} / \mathrm{a}$ & $\mathrm{J}$ \\
\hline DST Simulant & Wash 2 & S09R000666 & Fluoride & $\mathrm{ug} / \mathrm{mL}$ & $<0.622$ & $\mathrm{n} / \mathrm{a}$ & $\mathrm{n} / \mathrm{a}$ & $\mathrm{n} / \mathrm{a}$ & $\mathrm{U}$ \\
\hline DST Simulant & Wash 2 & S09R000666 & Chloride & $\mathrm{ug} / \mathrm{mL}$ & $<0.313$ & $\mathrm{n} / \mathrm{a}$ & $\mathrm{n} / \mathrm{a}$ & $\mathrm{n} / \mathrm{a}$ & $\mathrm{U}$ \\
\hline DST Simulant & Wash 2 & S09R000666 & Nitrite & $\mathrm{ug} / \mathrm{mL}$ & 25.8 & $\mathrm{n} / \mathrm{a}$ & $\mathrm{n} / \mathrm{a}$ & $n / a$ & \\
\hline DST Simulant & Wash 2 & S09R000666 & Bromide & $\mathrm{ug} / \mathrm{mL}$ & $<2.39$ & $n / a$ & $\mathrm{n} / \mathrm{a}$ & $\mathrm{n} / \mathrm{a}$ & $\mathrm{U}$ \\
\hline DST Simulant & Wash 2 & S09R000666 & Nitrate & $\mathrm{ug} / \mathrm{mL}$ & 41.4 & $\mathrm{n} / \mathrm{a}$ & $\mathrm{n} / \mathrm{a}$ & $\mathrm{n} / \mathrm{a}$ & \\
\hline DST Simulant & Wash 2 & S09R000666 & Phosphate & $\mathrm{ug} / \mathrm{mL}$ & $<3.85$ & $\mathrm{n} / \mathrm{a}$ & $\mathrm{n} / \mathrm{a}$ & $n / a$ & $\mathrm{U}$ \\
\hline DST Simulant & Wash 2 & S09R000666 & Sulfate & $\mathrm{ug} / \mathrm{mL}$ & $<2.21$ & $\mathrm{n} / \mathrm{a}$ & $\mathrm{n} / \mathrm{a}$ & $\mathrm{n} / \mathrm{a}$ & $\mathrm{U}$ \\
\hline DST Simulant & Wash 2 & S09R000666 & Oxalate & $\mathrm{ug} / \mathrm{mL}$ & $<10.6$ & $\mathrm{n} / \mathrm{a}$ & $\mathrm{n} / \mathrm{a}$ & $\mathrm{n} / \mathrm{a}$ & $\mathrm{U}$ \\
\hline DST Simulant & Wash 2 & S09R000666 & Aluminum & $\mathrm{ug} / \mathrm{mL}$ & 25.9 & $\mathrm{n} / \mathrm{a}$ & $\mathrm{n} / \mathrm{a}$ & $\mathrm{n} / \mathrm{a}$ & \\
\hline DST Simulant & Wash 2 & S09R000666 & Lithium & $\mathrm{ug} / \mathrm{mL}$ & 9.67 & $\mathrm{n} / \mathrm{a}$ & $\mathrm{n} / \mathrm{a}$ & $\mathrm{n} / \mathrm{a}$ & \\
\hline DST Simulant & Wash 2 & S09R000666 & Phosphorus & $\mathrm{ug} / \mathrm{mL}$ & 0.129 & $\mathrm{n} / \mathrm{a}$ & $\mathrm{n} / \mathrm{a}$ & $\mathrm{n} / \mathrm{a}$ & J \\
\hline DST Simulant & Wash 2 & S09R000666 & Sulfur & $\mathrm{ug} / \mathrm{mL}$ & $<0.100$ & $\mathrm{n} / \mathrm{a}$ & $\mathrm{n} / \mathrm{a}$ & $\mathrm{n} / \mathrm{a}$ & $\mathrm{U}$ \\
\hline DST Simulant & Wash 2 & S09R000666 & Silicon & $\mathrm{ug} / \mathrm{mL}$ & 0.0793 & $n / a$ & $\mathrm{n} / \mathrm{a}$ & $n / a$ & JY \\
\hline DST Simulant & Wash 2 & S09R000666 & Cesium-133 & $\mathrm{ug} / \mathrm{mL}$ & 0.0354 & $\mathrm{n} / \mathrm{a}$ & $\mathrm{n} / \mathrm{a}$ & $\mathrm{n} / \mathrm{a}$ & \\
\hline DST Simulant & Wash 2 & S09R000666 & Hydroxide & $\mathrm{ug} / \mathrm{mL}$ & 35.2 & $\mathrm{n} / \mathrm{a}$ & $\mathrm{n} / \mathrm{a}$ & $\mathrm{n} / \mathrm{a}$ & \\
\hline DST Simulant & Wash 2 & S09R000666 & Total inorganic carbon & $\mathrm{ug} / \mathrm{mL}$ & 8.00 & $\mathrm{n} / \mathrm{a}$ & $\mathrm{n} / \mathrm{a}$ & $\mathrm{n} / \mathrm{a}$ & $\mathrm{J}$ \\
\hline DST Simulant & Wash 2 & S09R000666 & Total organic carbon & $\mathrm{ug} / \mathrm{mL}$ & 24.0 & $\mathrm{n} / \mathrm{a}$ & $\mathrm{n} / \mathrm{a}$ & $\mathrm{n} / \mathrm{a}$ & $\mathrm{J}$ \\
\hline DST Simulant & Wash 3 & S09R000667 & Fluoride & $\mathrm{ug} / \mathrm{mL}$ & 0.271 & $\mathrm{n} / \mathrm{a}$ & $\mathrm{n} / \mathrm{a}$ & $\mathrm{n} / \mathrm{a}$ & \\
\hline DST Simulant & Wash 3 & S09R000667 & Chloride & $\mathrm{ug} / \mathrm{mL}$ & 1.47 & $\mathrm{n} / \mathrm{a}$ & $\mathrm{n} / \mathrm{a}$ & $\mathrm{n} / \mathrm{a}$ & \\
\hline DST Simulant & Wash 3 & S09R000667 & Nitrite & $\mathrm{ug} / \mathrm{mL}$ & 18.5 & $\mathrm{n} / \mathrm{a}$ & $\mathrm{n} / \mathrm{a}$ & $\mathrm{n} / \mathrm{a}$ & \\
\hline DST Simulant & Wash 3 & S09R000667 & Bromide & $\mathrm{ug} / \mathrm{mL}$ & $<0.0237$ & $\mathrm{n} / \mathrm{a}$ & $\mathrm{n} / \mathrm{a}$ & $\mathrm{n} / \mathrm{a}$ & $\mathrm{U}$ \\
\hline DST Simulant & Wash 3 & S09R000667 & Nitrate & $\mathrm{ug} / \mathrm{mL}$ & 22.5 & $\mathrm{n} / \mathrm{a}$ & $\mathrm{n} / \mathrm{a}$ & $\mathrm{n} / \mathrm{a}$ & \\
\hline DST Simulant & Wash 3 & S09R000667 & Phosphate & $\mathrm{ug} / \mathrm{mL}$ & 1.06 & $n / a$ & $\mathrm{n} / \mathrm{a}$ & $\mathrm{n} / \mathrm{a}$ & \\
\hline DST Simulant & Wash 3 & S09R000667 & Sulfate & $\mathrm{ug} / \mathrm{mL}$ & 2.13 & $\mathrm{n} / \mathrm{a}$ & $\mathrm{n} / \mathrm{a}$ & $\mathrm{n} / \mathrm{a}$ & \\
\hline DST Simulant & Wash 3 & S09R000667 & Oxalate & $\mathrm{ug} / \mathrm{mL}$ & $<0.105$ & $\mathrm{n} / \mathrm{a}$ & $\mathrm{n} / \mathrm{a}$ & $\mathrm{n} / \mathrm{a}$ & $\mathrm{U}$ \\
\hline DST Simulant & Wash 3 & S09R000667 & Aluminum & $\mathrm{ug} / \mathrm{mL}$ & 10.1 & $\mathrm{n} / \mathrm{a}$ & $\mathrm{n} / \mathrm{a}$ & $\mathrm{n} / \mathrm{a}$ & \\
\hline DST Simulant & Wash 3 & S09R000667 & Lithium & $\mathrm{ug} / \mathrm{mL}$ & 5.58 & $\mathrm{n} / \mathrm{a}$ & $\mathrm{n} / \mathrm{a}$ & $\mathrm{n} / \mathrm{a}$ & \\
\hline
\end{tabular}


LAB-RPT-10-00003

Revision 0

\begin{tabular}{|c|c|c|c|c|c|c|c|c|c|}
\hline ID & & SAMPLE & ANALYTE & UNIT & RESULT & DUP. & AVE. & RPD & QA \\
\hline DST Simulant & Wash 3 & S09R000667 & Phosphorus & $\mathrm{ug} / \mathrm{mL}$ & 0.129 & $\mathrm{n} / \mathrm{a}$ & $\mathrm{n} / \mathrm{a}$ & $\mathrm{n} / \mathrm{a}$ & $\mathrm{J}$ \\
\hline DST Simulant & Wash 3 & S09R000667 & Sulfur & $\mathrm{ug} / \mathrm{mL}$ & 0.715 & $n / a$ & $\mathrm{n} / \mathrm{a}$ & $\mathrm{n} / \mathrm{a}$ & $\mathrm{J}$ \\
\hline DST Simulant & Wash 3 & S09R000667 & Silicon & $\mathrm{ug} / \mathrm{mL}$ & 0.461 & $\mathrm{n} / \mathrm{a}$ & $\mathrm{n} / \mathrm{a}$ & $\mathrm{n} / \mathrm{a}$ & \\
\hline DST Simulant & Wash 3 & S09R000667 & Cesium-133 & $\mathrm{ug} / \mathrm{mL}$ & 0.0175 & $\mathrm{n} / \mathrm{a}$ & $n / a$ & $\mathrm{n} / \mathrm{a}$ & \\
\hline DST Simulant & Wash 3 & S09R000667 & Hydroxide & $\mathrm{ug} / \mathrm{mL}$ & 15.3 & $\mathrm{n} / \mathrm{a}$ & $\mathrm{n} / \mathrm{a}$ & $\mathrm{n} / \mathrm{a}$ & \\
\hline DST Simulant & Wash 3 & S09R000667 & Total inorganic carbon & $\mathrm{ug} / \mathrm{mL}$ & 10.5 & $n / a$ & $n / a$ & $\mathrm{n} / \mathrm{a}$ & $\mathrm{J}$ \\
\hline DST Simulant & Wash 3 & S09R000667 & Total organic carbon & $\mathrm{ug} / \mathrm{mL}$ & 18.0 & $n / a$ & $n / a$ & $\mathrm{n} / \mathrm{a}$ & $\mathrm{J}$ \\
\hline DST Simulant & Wash 4 & S09R000668 & Fluoride & $\mathrm{ug} / \mathrm{mL}$ & 0.325 & $\mathrm{n} / \mathrm{a}$ & $\mathrm{n} / \mathrm{a}$ & $\mathrm{n} / \mathrm{a}$ & \\
\hline DST Simulant & Wash 4 & S09R000668 & Chloride & $\mathrm{ug} / \mathrm{mL}$ & 1.14 & $\mathrm{n} / \mathrm{a}$ & $n / a$ & $\mathrm{n} / \mathrm{a}$ & \\
\hline DST Simulant & Wash 4 & S09R000668 & Nitrite & $\mathrm{ug} / \mathrm{mL}$ & 16.9 & $\mathrm{n} / \mathrm{a}$ & $\mathrm{n} / \mathrm{a}$ & $\mathrm{n} / \mathrm{a}$ & \\
\hline DST Simulant & Wash 4 & S09R000668 & Bromide & $\mathrm{ug} / \mathrm{mL}$ & $<0.0237$ & $\mathrm{n} / \mathrm{a}$ & $\mathrm{n} / \mathrm{a}$ & $\mathrm{n} / \mathrm{a}$ & $\mathrm{U}$ \\
\hline DST Simulant & Wash 4 & S09R000668 & Nitrate & $\mathrm{ug} / \mathrm{mL}$ & 20.4 & $\mathrm{n} / \mathrm{a}$ & $\mathrm{n} / \mathrm{a}$ & $\mathrm{n} / \mathrm{a}$ & \\
\hline DST Simulant & Wash 4 & S09R000668 & Phosphate & $\mathrm{ug} / \mathrm{mL}$ & 5.42 & $\mathrm{n} / \mathrm{a}$ & $\mathrm{n} / \mathrm{a}$ & $n / a$ & \\
\hline DST Simulant & Wash 4 & S09R000668 & Sulfate & $\mathrm{ug} / \mathrm{mL}$ & 2.98 & $\mathrm{n} / \mathrm{a}$ & $\mathrm{n} / \mathrm{a}$ & $\mathrm{n} / \mathrm{a}$ & \\
\hline DST Simulant & Wash 4 & S09R000668 & Oxalate & $\mathrm{ug} / \mathrm{mL}$ & $<0.105$ & $\mathrm{n} / \mathrm{a}$ & $\mathrm{n} / \mathrm{a}$ & $\mathrm{n} / \mathrm{a}$ & $\mathrm{U}$ \\
\hline DST Simulant & Wash 4 & S09R000668 & Aluminum & $\mathrm{ug} / \mathrm{mL}$ & 10.7 & $\mathrm{n} / \mathrm{a}$ & $\mathrm{n} / \mathrm{a}$ & $\mathrm{n} / \mathrm{a}$ & \\
\hline DST Simulant & Wash 4 & S09R000668 & Lithium & $\mathrm{ug} / \mathrm{mL}$ & 5.87 & $\mathrm{n} / \mathrm{a}$ & $\mathrm{n} / \mathrm{a}$ & $\mathrm{n} / \mathrm{a}$ & \\
\hline DST Simulant & Wash 4 & S09R000668 & Phosphorus & $\mathrm{ug} / \mathrm{mL}$ & 1.72 & $\mathrm{n} / \mathrm{a}$ & $\mathrm{n} / \mathrm{a}$ & $\mathrm{n} / \mathrm{a}$ & \\
\hline DST Simulant & Wash 4 & S09R000668 & Sulfur & $\mathrm{ug} / \mathrm{mL}$ & 0.992 & $\mathrm{n} / \mathrm{a}$ & $\mathrm{n} / \mathrm{a}$ & $\mathrm{n} / \mathrm{a}$ & $\mathrm{J}$ \\
\hline DST Simulant & Wash 4 & S09R000668 & Silicon & $\mathrm{ug} / \mathrm{mL}$ & 0.853 & $\mathrm{n} / \mathrm{a}$ & $\mathrm{n} / \mathrm{a}$ & $n / a$ & \\
\hline DST Simulant & Wash 4 & S09R000668 & Cesium-133 & $\mathrm{ug} / \mathrm{mL}$ & 0.0147 & $\mathrm{n} / \mathrm{a}$ & $\mathrm{n} / \mathrm{a}$ & $\mathrm{n} / \mathrm{a}$ & \\
\hline DST Simulant & Wash 4 & S09R000668 & Hydroxide & $\mathrm{ug} / \mathrm{mL}$ & 15.9 & $\mathrm{n} / \mathrm{a}$ & $\mathrm{n} / \mathrm{a}$ & $\mathrm{n} / \mathrm{a}$ & $\mathrm{J}$ \\
\hline DST Simulant & Wash 4 & S09R000668 & Total inorganic carbon & $\mathrm{ug} / \mathrm{mL}$ & $<7.00$ & $\mathrm{n} / \mathrm{a}$ & $\mathrm{n} / \mathrm{a}$ & $\mathrm{n} / \mathrm{a}$ & $\mathrm{U}$ \\
\hline DST Simulant & Wash 4 & S09R000668 & Total organic carbon & $\mathrm{ug} / \mathrm{mL}$ & $<15.0$ & $\mathrm{n} / \mathrm{a}$ & $\mathrm{n} / \mathrm{a}$ & $\mathrm{n} / \mathrm{a}$ & $\mathrm{U}$ \\
\hline SST Simulant & Filter Cake & S09R000674 & Percent water & $\%$ & 2.76 & $\mathrm{n} / \mathrm{a}$ & $\mathrm{n} / \mathrm{a}$ & $\mathrm{n} / \mathrm{a}$ & \\
\hline SST Simulant & Filter Cake & S09R000674 & Total organic carbon & $\mathrm{ug} / \mathrm{g}$ & $<301$ & $\mathrm{n} / \mathrm{a}$ & $\mathrm{n} / \mathrm{a}$ & $n / a$ & $\mathrm{U}$ \\
\hline SST Simulant & Filter Cake & S09R000674 & Total inorganic carbon & $\mathrm{ug} / \mathrm{g}$ & $2.31 \mathrm{E}+04$ & $\mathrm{n} / \mathrm{a}$ & $\mathrm{n} / \mathrm{a}$ & $n / a$ & \\
\hline SST Simulant & Filter Cake & S09R000676 & Hydroxide & $\mathrm{ug} / \mathrm{g}$ & $2.19 \mathrm{E}+04$ & $\mathrm{n} / \mathrm{a}$ & $\mathrm{n} / \mathrm{a}$ & $\mathrm{n} / \mathrm{a}$ & \\
\hline SST Simulant & Filter Cake & S09R000678 & Aluminum & $\mathrm{ug} / \mathrm{g}$ & $1.29 \mathrm{E}+04$ & $\mathrm{n} / \mathrm{a}$ & $\mathrm{n} / \mathrm{a}$ & $\mathrm{n} / \mathrm{a}$ & \\
\hline SST Simulant & Filter Cake & S09R000678 & Lithium & $\mathrm{ug} / \mathrm{g}$ & $1.15 \mathrm{E}+05$ & $n / a$ & $\mathrm{n} / \mathrm{a}$ & $n / a$ & \\
\hline SST Simulant & Filter Cake & S09R000678 & Phosphorus & $u g / g$ & $1.73 \mathrm{E}+05$ & $\mathrm{n} / \mathrm{a}$ & $\mathrm{n} / \mathrm{a}$ & $n / a$ & \\
\hline SST Simulant & Filter Cake & S09R000678 & Sulfur & $\mathrm{ug} / \mathrm{g}$ & $1.03 \mathrm{E}+03$ & $\mathrm{n} / \mathrm{a}$ & $\mathrm{n} / \mathrm{a}$ & $\mathrm{n} / \mathrm{a}$ & \\
\hline SST Simulant & Filter Cake & S09R000678 & Silicon & $\mathrm{ug} / \mathrm{g}$ & $1.11 \mathrm{E}+03$ & $\mathrm{n} / \mathrm{a}$ & $\mathrm{n} / \mathrm{a}$ & $n / a$ & \\
\hline SST Simulant & Filter Cake & S09R000678 & Cesium-133 & $\mathrm{ug} / \mathrm{g}$ & 0.901 & $\mathrm{n} / \mathrm{a}$ & $\mathrm{n} / \mathrm{a}$ & $n / a$ & $\mathrm{~J}$ \\
\hline SST Simulant & Filtrate 1 & S09R000663 & Fluoride & $\mathrm{ug} / \mathrm{mL}$ & 372 & $n / a$ & $\mathrm{n} / \mathrm{a}$ & $\mathrm{n} / \mathrm{a}$ & \\
\hline SST Simulant & Filtrate 1 & S09R000663 & Chloride & $\mathrm{ug} / \mathrm{mL}$ & $2.79 \mathrm{E}+03$ & $\mathrm{n} / \mathrm{a}$ & $\mathrm{n} / \mathrm{a}$ & $\mathrm{n} / \mathrm{a}$ & \\
\hline SST Simulant & Filtrate 1 & S09R000663 & Nitrite & $\mathrm{ug} / \mathrm{mL}$ & $3.55 \mathrm{E}+04$ & $\mathrm{n} / \mathrm{a}$ & $\mathrm{n} / \mathrm{a}$ & $\mathrm{n} / \mathrm{a}$ & \\
\hline SST Simulant & Filtrate 1 & S09R000663 & Bromide & $\mathrm{ug} / \mathrm{mL}$ & $<26.3$ & $\mathrm{n} / \mathrm{a}$ & $\mathrm{n} / \mathrm{a}$ & $\mathrm{n} / \mathrm{a}$ & $\mathrm{U}$ \\
\hline SST Simulant & Filtrate 1 & S09R000663 & Nitrate & $\mathrm{ug} / \mathrm{mL}$ & $2.36 \mathrm{E}+05$ & $\mathrm{n} / \mathrm{a}$ & $\mathrm{n} / \mathrm{a}$ & $\mathrm{n} / \mathrm{a}$ & \\
\hline SST Simulant & Filtrate 1 & S09R000663 & Phosphate & $\mathrm{ug} / \mathrm{mL}$ & $5.03 \mathrm{E}+03$ & $\mathrm{n} / \mathrm{a}$ & $\mathrm{n} / \mathrm{a}$ & $\mathrm{n} / \mathrm{a}$ & \\
\hline SST Simulant & Filtrate 1 & S09R000663 & Sulfate & $\mathrm{ug} / \mathrm{mL}$ & $1.37 \mathrm{E}+04$ & $\mathrm{n} / \mathrm{a}$ & $\mathrm{n} / \mathrm{a}$ & $\mathrm{n} / \mathrm{a}$ & \\
\hline SST Simulant & Filtrate 1 & S09R000663 & Oxalate & $\mathrm{ug} / \mathrm{mL}$ & 995 & $\mathrm{n} / \mathrm{a}$ & $\mathrm{n} / \mathrm{a}$ & $\mathrm{n} / \mathrm{a}$ & \\
\hline SST Simulant & Filtrate 1 & S09R000663 & Aluminum & $\mathrm{ug} / \mathrm{mL}$ & $1.21 \mathrm{E}+04$ & $\mathrm{n} / \mathrm{a}$ & $\mathrm{n} / \mathrm{a}$ & $\mathrm{n} / \mathrm{a}$ & \\
\hline SST Simulant & Filtrate 1 & S09R000663 & Lithium & $\mathrm{ug} / \mathrm{mL}$ & $<0.600$ & $\mathrm{n} / \mathrm{a}$ & $\mathrm{n} / \mathrm{a}$ & $\mathrm{n} / \mathrm{a}$ & $\mathrm{U}$ \\
\hline SST Simulant & Filtrate 1 & S09R000663 & Phosphorus & $\mathrm{ug} / \mathrm{mL}$ & $1.76 \mathrm{E}+03$ & $\mathrm{n} / \mathrm{a}$ & $\mathrm{n} / \mathrm{a}$ & $\mathrm{n} / \mathrm{a}$ & \\
\hline SST Simulant & Filtrate 1 & S09R000663 & Sulfur & $\mathrm{ug} / \mathrm{mL}$ & $4.46 \mathrm{E}+03$ & $\mathrm{n} / \mathrm{a}$ & $\mathrm{n} / \mathrm{a}$ & $\mathrm{n} / \mathrm{a}$ & \\
\hline SST Simulant & Filtrate 1 & S09R000663 & Silicon & $\mathrm{ug} / \mathrm{mL}$ & 105 & $\mathrm{n} / \mathrm{a}$ & $\mathrm{n} / \mathrm{a}$ & $\mathrm{n} / \mathrm{a}$ & \\
\hline SST Simulant & Filtrate 1 & S09R000663 & Cesium-133 & $\mathrm{ug} / \mathrm{mL}$ & 15.5 & $\mathrm{n} / \mathrm{a}$ & $\mathrm{n} / \mathrm{a}$ & $\mathrm{n} / \mathrm{a}$ & \\
\hline
\end{tabular}


LAB-RPT-10-00003

Revision 0

\begin{tabular}{|c|c|c|c|c|c|c|c|c|c|}
\hline ID & & SAMPLE & ANALYTE & UNIT & RESULT & DUP. & AVE. & RPD & QA \\
\hline SST Simulant & Filtrate 1 & S09R000663 & Hydroxide & $\mathrm{ug} / \mathrm{mL}$ & $2.71 \mathrm{E}+04$ & $\mathrm{n} / \mathrm{a}$ & $\mathrm{n} / \mathrm{a}$ & $\mathrm{n} / \mathrm{a}$ & \\
\hline SST Simulant & Filtrate 1 & S09R000663 & Total inorganic carbon & $\mathrm{ug} / \mathrm{mL}$ & $7.50 \mathrm{E}+03$ & $6.63 \mathrm{E}+03$ & $7.06 \mathrm{E}+03$ & 12.3 & \\
\hline SST Simulant & Filtrate 1 & S09R000663 & Total organic carbon & $\mathrm{ug} / \mathrm{mL}$ & 378 & 474 & 426 & 22.5 & c \\
\hline SST Simulant & Filtrate 2 & S09R000664 & Fluoride & $\mathrm{ug} / \mathrm{mL}$ & $1.44 \mathrm{E}+03$ & $\mathrm{n} / \mathrm{a}$ & $\mathrm{n} / \mathrm{a}$ & $\mathrm{n} / \mathrm{a}$ & \\
\hline SST Simulant & Filtrate 2 & S09R000664 & Chloride & $\mathrm{ug} / \mathrm{mL}$ & $2.77 \mathrm{E}+03$ & $\mathrm{n} / \mathrm{a}$ & $\mathrm{n} / \mathrm{a}$ & $n / a$ & \\
\hline SST Simulant & Filtrate 2 & S09R000664 & Nitrite & $\mathrm{ug} / \mathrm{mL}$ & $3.62 \mathrm{E}+04$ & $\mathrm{n} / \mathrm{a}$ & $\mathrm{n} / \mathrm{a}$ & $\mathrm{n} / \mathrm{a}$ & \\
\hline SST Simulant & Filtrate 2 & S09R000664 & Bromide & $\mathrm{ug} / \mathrm{mL}$ & $<26.3$ & $n / a$ & $\mathrm{n} / \mathrm{a}$ & $n / a$ & $\mathrm{U}$ \\
\hline SST Simulant & Filtrate 2 & S09R000664 & Nitrate & $\mathrm{ug} / \mathrm{mL}$ & $2.45 \mathrm{E}+05$ & $\mathrm{n} / \mathrm{a}$ & $\mathrm{n} / \mathrm{a}$ & $\mathrm{n} / \mathrm{a}$ & \\
\hline SST Simulant & Filtrate 2 & S09R000664 & Phosphate & $\mathrm{ug} / \mathrm{mL}$ & 767 & $\mathrm{n} / \mathrm{a}$ & $\mathrm{n} / \mathrm{a}$ & $\mathrm{n} / \mathrm{a}$ & \\
\hline SST Simulant & Filtrate 2 & S09R000664 & Sulfate & $\mathrm{ug} / \mathrm{mL}$ & $1.32 \mathrm{E}+04$ & $\mathrm{n} / \mathrm{a}$ & $\mathrm{n} / \mathrm{a}$ & $\mathrm{n} / \mathrm{a}$ & \\
\hline SST Simulant & Filtrate 2 & S09R000664 & Oxalate & $\mathrm{ug} / \mathrm{mL}$ & $1.07 \mathrm{E}+03$ & $\mathrm{n} / \mathrm{a}$ & $\mathrm{n} / \mathrm{a}$ & $\mathrm{n} / \mathrm{a}$ & \\
\hline SST Simulant & Filtrate 2 & S09R000664 & Aluminum & $\mathrm{ug} / \mathrm{mL}$ & $1.11 \mathrm{E}+04$ & $\mathrm{n} / \mathrm{a}$ & $\mathrm{n} / \mathrm{a}$ & $\mathrm{n} / \mathrm{a}$ & \\
\hline SST Simulant & Filtrate 2 & S09R000664 & Lithium & $\mathrm{ug} / \mathrm{mL}$ & 248 & $\mathrm{n} / \mathrm{a}$ & $\mathrm{n} / \mathrm{a}$ & $n / a$ & \\
\hline SST Simulant & Filtrate 2 & S09R000664 & Phosphorus & $\mathrm{ug} / \mathrm{mL}$ & 158 & $\mathrm{n} / \mathrm{a}$ & $\mathrm{n} / \mathrm{a}$ & $\mathrm{n} / \mathrm{a}$ & \\
\hline SST Simulant & Filtrate 2 & S09R000664 & Sulfur & $\mathrm{ug} / \mathrm{mL}$ & $4.49 \mathrm{E}+03$ & $\mathrm{n} / \mathrm{a}$ & $\mathrm{n} / \mathrm{a}$ & $\mathrm{n} / \mathrm{a}$ & \\
\hline SST Simulant & Filtrate 2 & S09R000664 & Silicon & $\mathrm{ug} / \mathrm{mL}$ & 84.2 & $\mathrm{n} / \mathrm{a}$ & $\mathrm{n} / \mathrm{a}$ & $\mathrm{n} / \mathrm{a}$ & \\
\hline SST Simulant & Filtrate 2 & S09R000664 & Cesium-133 & $\mathrm{ug} / \mathrm{mL}$ & 15.7 & $\mathrm{n} / \mathrm{a}$ & $\mathrm{n} / \mathrm{a}$ & $\mathrm{n} / \mathrm{a}$ & \\
\hline SST Simulant & Filtrate 2 & S09R000664 & Hydroxide & $\mathrm{ug} / \mathrm{mL}$ & $3.17 \mathrm{E}+04$ & $\mathrm{n} / \mathrm{a}$ & $\mathrm{n} / \mathrm{a}$ & $\mathrm{n} / \mathrm{a}$ & \\
\hline SST Simulant & Filtrate 2 & S09R000664 & Total inorganic carbon & $\mathrm{ug} / \mathrm{mL}$ & $7.22 \mathrm{E}+03$ & $\mathrm{n} / \mathrm{a}$ & $\mathrm{n} / \mathrm{a}$ & $\mathrm{n} / \mathrm{a}$ & \\
\hline SST Simulant & Filtrate 2 & S09R000664 & Total organic carbon & $\mathrm{ug} / \mathrm{mL}$ & 390 & $\mathrm{n} / \mathrm{a}$ & $\mathrm{n} / \mathrm{a}$ & $n / a$ & $\mathrm{c}$ \\
\hline SST Simulant & Wash 1 & S09R000669 & Fluoride & $\mathrm{ug} / \mathrm{mL}$ & 5.70 & $\mathrm{n} / \mathrm{a}$ & $\mathrm{n} / \mathrm{a}$ & $\mathrm{n} / \mathrm{a}$ & \\
\hline SST Simulant & Wash 1 & S09R000669 & Chloride & $\mathrm{ug} / \mathrm{mL}$ & 10.5 & $\mathrm{n} / \mathrm{a}$ & $\mathrm{n} / \mathrm{a}$ & $\mathrm{n} / \mathrm{a}$ & \\
\hline SST Simulant & Wash 1 & S09R000669 & Nitrite & $\mathrm{ug} / \mathrm{mL}$ & 112 & $\mathrm{n} / \mathrm{a}$ & $\mathrm{n} / \mathrm{a}$ & $\mathrm{n} / \mathrm{a}$ & \\
\hline SST Simulant & Wash 1 & S09R000669 & Bromide & $\mathrm{ug} / \mathrm{mL}$ & $<2.39$ & $n / a$ & $\mathrm{n} / \mathrm{a}$ & $\mathrm{n} / \mathrm{a}$ & $\mathrm{U}$ \\
\hline SST Simulant & Wash 1 & S09R000669 & Nitrate & $\mathrm{ug} / \mathrm{mL}$ & 758 & $\mathrm{n} / \mathrm{a}$ & $\mathrm{n} / \mathrm{a}$ & $\mathrm{n} / \mathrm{a}$ & \\
\hline SST Simulant & Wash 1 & S09R000669 & Phosphate & $\mathrm{ug} / \mathrm{mL}$ & 334 & $\mathrm{n} / \mathrm{a}$ & $\mathrm{n} / \mathrm{a}$ & $\mathrm{n} / \mathrm{a}$ & \\
\hline SST Simulant & Wash 1 & S09R000669 & Sulfate & $\mathrm{ug} / \mathrm{mL}$ & 431 & $\mathrm{n} / \mathrm{a}$ & $\mathrm{n} / \mathrm{a}$ & $n / a$ & \\
\hline SST Simulant & Wash 1 & S09R000669 & Oxalate & $\mathrm{ug} / \mathrm{mL}$ & $<10.6$ & $\mathrm{n} / \mathrm{a}$ & $\mathrm{n} / \mathrm{a}$ & $\mathrm{n} / \mathrm{a}$ & $\mathrm{U}$ \\
\hline SST Simulant & Wash 1 & S09R000669 & Aluminum & $\mathrm{ug} / \mathrm{mL}$ & 41.5 & 41.0 & 41.3 & 1.12 & \\
\hline SST Simulant & Wash 1 & S09R000669 & Lithium & $\mathrm{ug} / \mathrm{mL}$ & 76.4 & 75.7 & 76.1 & 0.89 & \\
\hline SST Simulant & Wash 1 & S09R000669 & Phosphorus & $\mathrm{ug} / \mathrm{mL}$ & 119 & 117 & 118 & 1.77 & \\
\hline SST Simulant & Wash 1 & S09R000669 & Sulfur & $\mathrm{ug} / \mathrm{mL}$ & 148 & 146 & 147 & 1.43 & \\
\hline SST Simulant & Wash 1 & S09R000669 & Silicon & $\mathrm{ug} / \mathrm{mL}$ & 1.59 & 1.59 & 1.59 & 0.25 & \\
\hline SST Simulant & Wash 1 & S09R000669 & Cesium-133 & $\mathrm{ug} / \mathrm{mL}$ & 0.0492 & $\mathrm{n} / \mathrm{a}$ & $\mathrm{n} / \mathrm{a}$ & $\mathrm{n} / \mathrm{a}$ & $\mathrm{J}$ \\
\hline SST Simulant & Wash 1 & S09R000669 & Hydroxide & $\mathrm{ug} / \mathrm{mL}$ & 106 & $\mathrm{n} / \mathrm{a}$ & $\mathrm{n} / \mathrm{a}$ & $\mathrm{n} / \mathrm{a}$ & \\
\hline SST Simulant & Wash 1 & S09R000669 & Total inorganic carbon & $\mathrm{ug} / \mathrm{mL}$ & 110 & $\mathrm{n} / \mathrm{a}$ & $\mathrm{n} / \mathrm{a}$ & $\mathrm{n} / \mathrm{a}$ & \\
\hline SST Simulant & Wash 1 & S09R000669 & Total organic carbon & $\mathrm{ug} / \mathrm{mL}$ & 129 & $\mathrm{n} / \mathrm{a}$ & $\mathrm{n} / \mathrm{a}$ & $\mathrm{n} / \mathrm{a}$ & $\mathrm{J}$ \\
\hline SST Simulant & Wash 2 & S09R000670 & Fluoride & $\mathrm{ug} / \mathrm{mL}$ & 4.23 & $\mathrm{n} / \mathrm{a}$ & $\mathrm{n} / \mathrm{a}$ & $\mathrm{n} / \mathrm{a}$ & \\
\hline SST Simulant & Wash 2 & S09R000670 & Chloride & $\mathrm{ug} / \mathrm{mL}$ & $<0.0341$ & $\mathrm{n} / \mathrm{a}$ & $\mathrm{n} / \mathrm{a}$ & $\mathrm{n} / \mathrm{a}$ & $\mathrm{U}$ \\
\hline SST Simulant & Wash 2 & S09R000670 & Nitrite & $\mathrm{ug} / \mathrm{mL}$ & 0.510 & $\mathrm{n} / \mathrm{a}$ & $\mathrm{n} / \mathrm{a}$ & $\mathrm{n} / \mathrm{a}$ & $\mathrm{J}$ \\
\hline SST Simulant & Wash 2 & S09R000670 & Bromide & $\mathrm{ug} / \mathrm{mL}$ & $<0.261$ & $\mathrm{n} / \mathrm{a}$ & $\mathrm{n} / \mathrm{a}$ & $\mathrm{n} / \mathrm{a}$ & $\mathrm{U}$ \\
\hline SST Simulant & Wash 2 & S09R000670 & Nitrate & $\mathrm{ug} / \mathrm{mL}$ & 4.42 & $\mathrm{n} / \mathrm{a}$ & $\mathrm{n} / \mathrm{a}$ & $\mathrm{n} / \mathrm{a}$ & \\
\hline SST Simulant & Wash 2 & S09R000670 & Phosphate & $\mathrm{ug} / \mathrm{mL}$ & 142 & $\mathrm{n} / \mathrm{a}$ & $\mathrm{n} / \mathrm{a}$ & $\mathrm{n} / \mathrm{a}$ & \\
\hline SST Simulant & Wash 2 & S09R000670 & Sulfate & $\mathrm{ug} / \mathrm{mL}$ & 2.10 & $n / a$ & $\mathrm{n} / \mathrm{a}$ & $\mathrm{n} / \mathrm{a}$ & $\mathrm{J}$ \\
\hline SST Simulant & Wash 2 & S09R000670 & Oxalate & $\mathrm{ug} / \mathrm{mL}$ & $<1.16$ & $\mathrm{n} / \mathrm{a}$ & $\mathrm{n} / \mathrm{a}$ & $\mathrm{n} / \mathrm{a}$ & $\mathrm{U}$ \\
\hline SST Simulant & Wash 2 & S09R000670 & Aluminum & $\mathrm{ug} / \mathrm{mL}$ & 1.01 & $\mathrm{n} / \mathrm{a}$ & $\mathrm{n} / \mathrm{a}$ & $\mathrm{n} / \mathrm{a}$ & \\
\hline SST Simulant & Wash 2 & S09R000670 & Lithium & $\mathrm{ug} / \mathrm{mL}$ & 34.7 & $\mathrm{n} / \mathrm{a}$ & $\mathrm{n} / \mathrm{a}$ & $\mathrm{n} / \mathrm{a}$ & \\
\hline SST Simulant & Wash 2 & S09R000670 & Phosphorus & $\mathrm{ug} / \mathrm{mL}$ & 51.4 & $\mathrm{n} / \mathrm{a}$ & $\mathrm{n} / \mathrm{a}$ & $\mathrm{n} / \mathrm{a}$ & \\
\hline
\end{tabular}


LAB-RPT-10-00003

Revision 0

\begin{tabular}{|c|c|c|c|c|c|c|c|c|c|}
\hline ID & & SAMPLE & ANALYTE & UNIT & RESULT & DUP. & AVE. & RPD & QA \\
\hline SST Simulant & Wash 2 & S09R000670 & Sulfur & $\mathrm{ug} / \mathrm{mL}$ & 0.742 & $\mathrm{n} / \mathrm{a}$ & $\mathrm{n} / \mathrm{a}$ & $\mathrm{n} / \mathrm{a}$ & $\mathrm{J}$ \\
\hline SST Simulant & Wash 2 & S09R000670 & Silicon & $\mathrm{ug} / \mathrm{mL}$ & 0.523 & $n / a$ & $\mathrm{n} / \mathrm{a}$ & $\mathrm{n} / \mathrm{a}$ & $\mathrm{Y}$ \\
\hline SST Simulant & Wash 2 & S09R000670 & Cesium- 133 & $\mathrm{ug} / \mathrm{mL}$ & $3.83 \mathrm{E}-04$ & $\mathrm{n} / \mathrm{a}$ & $\mathrm{n} / \mathrm{a}$ & $\mathrm{n} / \mathrm{a}$ & \\
\hline SST Simulant & Wash 2 & S09R000670 & Hydroxide & $\mathrm{ug} / \mathrm{mL}$ & 11.5 & $\mathrm{n} / \mathrm{a}$ & $n / a$ & $\mathrm{n} / \mathrm{a}$ & $\mathrm{J}$ \\
\hline SST Simulant & Wash 2 & S09R000670 & Total inorganic carbon & $\mathrm{ug} / \mathrm{mL}$ & 14.0 & $\mathrm{n} / \mathrm{a}$ & $\mathrm{n} / \mathrm{a}$ & $\mathrm{n} / \mathrm{a}$ & $\mathrm{J}$ \\
\hline SST Simulant & Wash 2 & S09R000670 & Total organic carbon & $\mathrm{ug} / \mathrm{mL}$ & 31.5 & $n / a$ & $n / a$ & $\mathrm{n} / \mathrm{a}$ & $\mathrm{J}$ \\
\hline SST Simulant & Wash 3 & S09R000671 & Fluoride & $\mathrm{ug} / \mathrm{mL}$ & 1.03 & $n / a$ & $n / a$ & $\mathrm{n} / \mathrm{a}$ & \\
\hline SST Simulant & Wash 3 & S09R000671 & Chloride & $\mathrm{ug} / \mathrm{mL}$ & $<0.0341$ & $\mathrm{n} / \mathrm{a}$ & $\mathrm{n} / \mathrm{a}$ & $\mathrm{n} / \mathrm{a}$ & $\mathrm{U}$ \\
\hline SST Simulant & Wash 3 & S09R000671 & Nitrite & $\mathrm{ug} / \mathrm{mL}$ & $<0.440$ & $\mathrm{n} / \mathrm{a}$ & $n / a$ & $\mathrm{n} / \mathrm{a}$ & $\mathrm{U}$ \\
\hline SST Simulant & Wash 3 & S09R000671 & Bromide & $\mathrm{ug} / \mathrm{mL}$ & $<0.261$ & $\mathrm{n} / \mathrm{a}$ & $n / a$ & $\mathrm{n} / \mathrm{a}$ & $\mathrm{U}$ \\
\hline SST Simulant & Wash 3 & S09R000671 & Nitrate & $\mathrm{ug} / \mathrm{mL}$ & 1.93 & $\mathrm{n} / \mathrm{a}$ & $\mathrm{n} / \mathrm{a}$ & $\mathrm{n} / \mathrm{a}$ & $\mathrm{J}$ \\
\hline SST Simulant & Wash 3 & S09R000671 & Phosphate & $\mathrm{ug} / \mathrm{mL}$ & 83.4 & $n / a$ & $\mathrm{n} / \mathrm{a}$ & $\mathrm{n} / \mathrm{a}$ & \\
\hline SST Simulant & Wash 3 & S09R000671 & Sulfate & $\mathrm{ug} / \mathrm{mL}$ & 0.915 & $\mathrm{n} / \mathrm{a}$ & $\mathrm{n} / \mathrm{a}$ & $n / a$ & $J$ \\
\hline SST Simulant & Wash 3 & S09R000671 & Oxalate & $\mathrm{ug} / \mathrm{mL}$ & $<1.16$ & $\mathrm{n} / \mathrm{a}$ & $\mathrm{n} / \mathrm{a}$ & $\mathrm{n} / \mathrm{a}$ & $\mathrm{U}$ \\
\hline SST Simulant & Wash 3 & S09R000671 & Aluminum & $\mathrm{ug} / \mathrm{mL}$ & 0.534 & $\mathrm{n} / \mathrm{a}$ & $\mathrm{n} / \mathrm{a}$ & $\mathrm{n} / \mathrm{a}$ & \\
\hline SST Simulant & Wash 3 & S09R000671 & Lithium & $\mathrm{ug} / \mathrm{mL}$ & 20.7 & $\mathrm{n} / \mathrm{a}$ & $\mathrm{n} / \mathrm{a}$ & $\mathrm{n} / \mathrm{a}$ & \\
\hline SST Simulant & Wash 3 & S09R000671 & Phosphorus & $\mathrm{ug} / \mathrm{mL}$ & 30.5 & $n / a$ & $n / a$ & $n / a$ & \\
\hline SST Simulant & Wash 3 & S09R000671 & Sulfur & $\mathrm{ug} / \mathrm{mL}$ & 0.382 & $\mathrm{n} / \mathrm{a}$ & $\mathrm{n} / \mathrm{a}$ & $\mathrm{n} / \mathrm{a}$ & $\mathrm{J}$ \\
\hline SST Simulant & Wash 3 & S09R000671 & Silicon & $\mathrm{ug} / \mathrm{mL}$ & 0.323 & $\mathrm{n} / \mathrm{a}$ & $\mathrm{n} / \mathrm{a}$ & $\mathrm{n} / \mathrm{a}$ & $\mathrm{Y}$ \\
\hline SST Simulant & Wash 3 & S09R000671 & Cesium-133 & $\mathrm{ug} / \mathrm{mL}$ & $1.68 \mathrm{E}-04$ & $\mathrm{n} / \mathrm{a}$ & $\mathrm{n} / \mathrm{a}$ & $n / a$ & \\
\hline SST Simulant & Wash 3 & S09R000671 & Hydroxide & $\mathrm{ug} / \mathrm{mL}$ & $<9.22$ & $\mathrm{n} / \mathrm{a}$ & $\mathrm{n} / \mathrm{a}$ & $\mathrm{n} / \mathrm{a}$ & $\mathrm{U}$ \\
\hline SST Simulant & Wash 3 & S09R000671 & Total inorganic carbon & $\mathrm{ug} / \mathrm{mL}$ & 10.1 & $\mathrm{n} / \mathrm{a}$ & $\mathrm{n} / \mathrm{a}$ & $\mathrm{n} / \mathrm{a}$ & $\mathrm{J}$ \\
\hline SST Simulant & Wash 3 & S09R000671 & Total organic carbon & $\mathrm{ug} / \mathrm{mL}$ & 21.0 & $\mathrm{n} / \mathrm{a}$ & $\mathrm{n} / \mathrm{a}$ & $\mathrm{n} / \mathrm{a}$ & $\mathrm{J}$ \\
\hline SST Simulant & Wash 4 & S09R000672 & Fluoride & $\mathrm{ug} / \mathrm{mL}$ & 0.683 & $\mathrm{n} / \mathrm{a}$ & $\mathrm{n} / \mathrm{a}$ & $\mathrm{n} / \mathrm{a}$ & \\
\hline SST Simulant & Wash 4 & S09R000672 & Chloride & $\mathrm{ug} / \mathrm{mL}$ & $<0.0341$ & $\mathrm{n} / \mathrm{a}$ & $\mathrm{n} / \mathrm{a}$ & $\mathrm{n} / \mathrm{a}$ & $\mathrm{U}$ \\
\hline SST Simulant & Wash 4 & S09R000672 & Nitrite & $\mathrm{ug} / \mathrm{mL}$ & $<0.440$ & $\mathrm{n} / \mathrm{a}$ & $\mathrm{n} / \mathrm{a}$ & $\mathrm{n} / \mathrm{a}$ & $\mathrm{U}$ \\
\hline SST Simulant & Wash 4 & S09R000672 & Bromide & $\mathrm{ug} / \mathrm{mL}$ & $<0.261$ & $n / a$ & $\mathrm{n} / \mathrm{a}$ & $n / a$ & $\mathrm{U}$ \\
\hline SST Simulant & Wash 4 & S09R000672 & Nitrate & $\mathrm{ug} / \mathrm{mL}$ & 1.54 & $\mathrm{n} / \mathrm{a}$ & $\mathrm{n} / \mathrm{a}$ & $\mathrm{n} / \mathrm{a}$ & $\mathrm{J}$ \\
\hline SST Simulant & Wash 4 & S09R000672 & Phosphate & $\mathrm{ug} / \mathrm{mL}$ & 60.4 & $\mathrm{n} / \mathrm{a}$ & $\mathrm{n} / \mathrm{a}$ & $\mathrm{n} / \mathrm{a}$ & \\
\hline SST Simulant & Wash 4 & S09R000672 & Sulfate & $\mathrm{ug} / \mathrm{mL}$ & 54.5 & $\mathrm{n} / \mathrm{a}$ & $\mathrm{n} / \mathrm{a}$ & $n / a$ & \\
\hline SST Simulant & Wash 4 & S09R000672 & Oxalate & $\mathrm{ug} / \mathrm{mL}$ & $<1.16$ & $\mathrm{n} / \mathrm{a}$ & $\mathrm{n} / \mathrm{a}$ & $\mathrm{n} / \mathrm{a}$ & $\mathrm{U}$ \\
\hline SST Simulant & Wash 4 & S09R000672 & Aluminum & $\mathrm{ug} / \mathrm{mL}$ & 0.388 & $\mathrm{n} / \mathrm{a}$ & $\mathrm{n} / \mathrm{a}$ & $\mathrm{n} / \mathrm{a}$ & \\
\hline SST Simulant & Wash 4 & S09R000672 & Lithium & $\mathrm{ug} / \mathrm{mL}$ & 17.6 & $\mathrm{n} / \mathrm{a}$ & $\mathrm{n} / \mathrm{a}$ & $\mathrm{n} / \mathrm{a}$ & \\
\hline SST Simulant & Wash 4 & S09R000672 & Phosphorus & $\mathrm{ug} / \mathrm{mL}$ & 22.5 & $\mathrm{n} / \mathrm{a}$ & $\mathrm{n} / \mathrm{a}$ & $n / a$ & \\
\hline SST Simulant & Wash 4 & S09R000672 & Sulfur & $\mathrm{ug} / \mathrm{mL}$ & 19.7 & $\mathrm{n} / \mathrm{a}$ & $\mathrm{n} / \mathrm{a}$ & $\mathrm{n} / \mathrm{a}$ & \\
\hline SST Simulant & Wash 4 & S09R000672 & Silicon & $\mathrm{ug} / \mathrm{mL}$ & 0.264 & $\mathrm{n} / \mathrm{a}$ & $\mathrm{n} / \mathrm{a}$ & $\mathrm{n} / \mathrm{a}$ & JY \\
\hline SST Simulant & Wash 4 & S09R000672 & Cesium-133 & $\mathrm{ug} / \mathrm{mL}$ & $9.64 \mathrm{E}-05$ & $\mathrm{n} / \mathrm{a}$ & $\mathrm{n} / \mathrm{a}$ & $n / a$ & $\mathrm{~J}$ \\
\hline SST Simulant & Wash 4 & S09R000672 & Hydroxide & $\mathrm{ug} / \mathrm{mL}$ & $<9.22$ & $\mathrm{n} / \mathrm{a}$ & $\mathrm{n} / \mathrm{a}$ & $\mathrm{n} / \mathrm{a}$ & $\mathrm{U}$ \\
\hline SST Simulant & Wash 4 & S09R000672 & Total inorganic carbon & $\mathrm{ug} / \mathrm{mL}$ & 14.0 & $\mathrm{n} / \mathrm{a}$ & $\mathrm{n} / \mathrm{a}$ & $\mathrm{n} / \mathrm{a}$ & $\mathrm{J}$ \\
\hline SST Simulant & Wash 4 & S09R000672 & Total organic carbon & $\mathrm{ug} / \mathrm{mL}$ & 18.0 & $\mathrm{n} / \mathrm{a}$ & $\mathrm{n} / \mathrm{a}$ & $\mathrm{n} / \mathrm{a}$ & $\mathrm{J}$ \\
\hline
\end{tabular}

$\mathrm{n} / \mathrm{a}=$ Not Analyzed, ND $=$ Not Detected

Qualifiers:

$J$ - Estimated

U - Less Than Detection Limit

$\mathrm{Y}$ - Comment

c - RPD Outside Range 


\section{Electronically Approved by:}

UserName: Duncan, James (h0079048)

Title: APD Chemist

Date: Thursday, 08 April 2010, 01:01 PM Pacific Daylight Time Meaning: Annroved bv the author or delegate

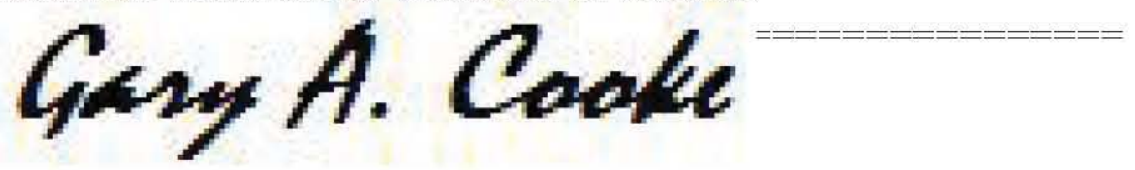

UserName: Cooke, Gary (h0410221)

Title: APD Chemist

Date: Thursday, 08 April 2010, 03:28 PM Pacific Daylight Time Meaning: Additional approval obtained

UserName: Sams, Terry (h0068391)

Title:

Date: Thursday, 08 April 2010, 04:28 PM Pacific Daylight Time Meaning: Approved by the customer or delegate

UserName: Seidel, Cary (h0009079)

Title: APD Manager

Date: Friday, 09 April 2010, 07:30 AM Pacific Daylight Time Meaning: Approved by the APD Manager or delegate 